Prepared in cooperation with Idaho Power Company

\title{
Water Column and Bed-Sediment Core Samples Collected from Brownlee Reservoir near Oxbow, Oregon, 2012
}

Data Series 809 



\section{Water Column and Bed-Sediment Core Samples Collected from Brownlee Reservoir near Oxbow, Oregon, 2012}

By Ryan L. Fosness, U.S. Geological Survey; Jesse Naymik, Idaho Power Company; Candice B. Hopkins, U.S. Geological Survey; and John F. DeWild, U.S. Geological Survey

Prepared in cooperation with Idaho Power Company

Data Series 809 


\title{
U.S. Department of the Interior SALLY JEWELL, Secretary
}

\section{U.S. Geological Survey Suzette M. Kimball, Acting Director}

\author{
U.S. Geological Survey, Reston, Virginia: 2013
}

For more information on the USGS - the Federal source for science about the Earth, its natural and living resources, natural hazards, and the environment, visit http://www.usgs.gov or call 1-888-ASK-USGS.

For an overview of USGS information products, including maps, imagery, and publications, visit http://www.usgs.gov/pubprod

To order this and other USGS information products, visit http://store.usgs.gov

Any use of trade, firm, or product names is for descriptive purposes only and does not imply endorsement by the U.S. Government.

Although this information product, for the most part, is in the public domain, it also may contain copyrighted materials as noted in the text. Permission to reproduce copyrighted items must be secured from the copyright owner.

Suggested citation:

Fosness, R.L, Naymik, Jesse, Hopkins, C.B., and DeWild, J.F., 2013, Water column and bed-sediment core samples collected from Brownlee Reservoir near Oxbow, Oregon, 2012: U.S. Geological Survey Data Series 809, 44 p., http://dx.doi.org/10.3133/ds809

ISSN 2327-638X (online) 


\section{Contents}

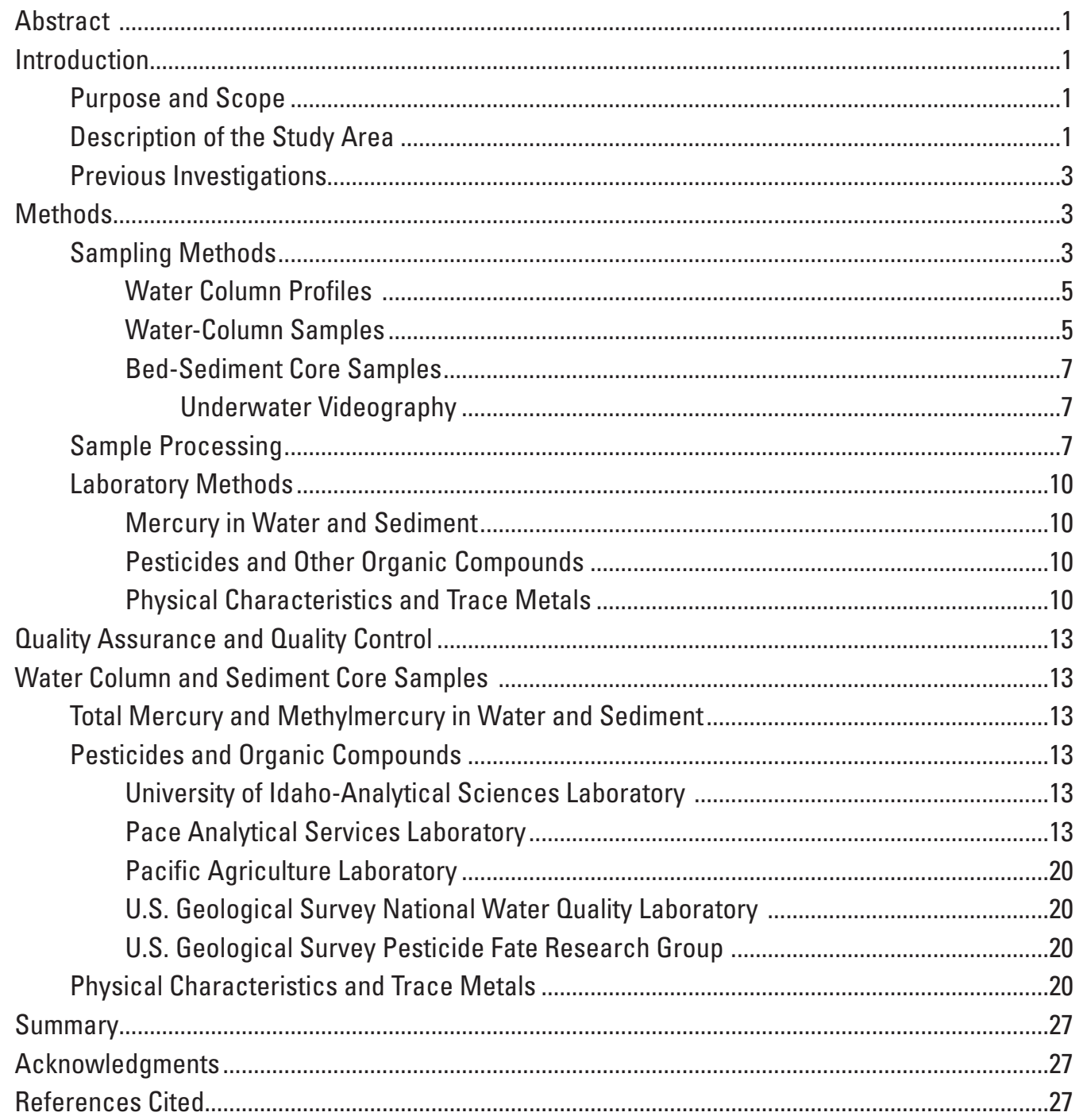




\section{Figures}

1. Map showing Lower Snake River drainage basin and tributary subbasins to Brownlee Reservoir near Oxbow, Oregon

2. Map showing locations where water-column samples and bed-sediment cores were collected from Brownlee Reservoir near Oxbow, Oregon, May 7-9, 2012 . .4

3. Photograph showing Sea-Bird Electronics, Inc. SEACAT Profiler CTD SBE-19plus, used to collect water column profiles of temperature, dissolved oxygen, and specific conductance in Brownlee Reservoir near Oxbow, Oregon, May 7-9, 2012 ........6

4. Photograph showing Niskin point-sampler used to collect water column samples in Brownlee Reservoir near Oxbow, Oregon, May 7-9, 2012.

5. Photograph showing Ballchek ${ }^{\mathrm{TM}}$ bed-sediment core sampler used in Brownlee Reservoir near Oxbow, Oregon, May 7-9, 2012.

6. Photographs showing typical core recovery and close-up of organic material on top of core sample collected from site 2 at Brownlee Reservoir near 0xbow, Oregon, May 7-9, 2012.

7. Photographs of underwater video camera system used to assist with sediment coring showing components of camera mounted on core barrel, and example image of collection of bed-sediment core sample in Brownlee Reservoir, Oregon, May 7-9, 2012

8. Photograph showing extraction process used to subsample bed-sediment cores collected from Brownlee Reservoir near Oxbow, Oregon, May 7-9, 2012. 10

\section{Tables}

1. Description of sites and number of water-column and bed-sediment core samples collected from Brownlee Reservoir near 0xbow, Oregon, May 7-9, 2012.

2. Techniques and associated methodologies used by laboratories to analyze water and bed-sediment core samples collected from Brownlee Reservoir near Oxbow, Oregon, May 7-9 2012

3. Total mercury, methylmercury, and dissolved organic carbon concentrations in water-column samples collected from Brownlee Reservoir near Oxbow, Oregon, May 7-9, 2012

4. Total mercury and methylmercury concentrations and selected physical characteristics of bed-sediment samples collected from Brownlee Reservoir near Oxbow, Oregon, May 7-9, 2012

5. Selected herbicide and carbamate insecticide concentrations in bed-sediment core samples collected at selected sites at Brownlee Reservoir near Oxbow, Oregon, May 7-9, 2012.

6. Laboratory results for glyphosate and breakdown product concentrations in bed-sediment core samples collected from selected sites at Brownlee Reservoir near Oxbow, Oregon, May 7-9, 2012

7. Wastewater compound concentrations in bed-sediment core samples collected from selected sites at Brownlee Reservoir near Oxbow, Oregon, May 7-9, 2012 


\section{Tables-Continued}

8. Pesticide concentrations in bed-sediment core samples collected from selected sites at Brownlee Reservoir near Oxbow, Oregon, May 7-9, 2012.

9. Physical characteristics of bed-sediment cores collected from selected sites at Brownlee Reservoir near Oxbow, Oregon, May 7-9, 2012. .26

10. Trace metal concentrations in bed-sediment core samples collected from selected sites at Brownlee Reservoir near Oxbow, Oregon, May 7-9, 2012.

11. Organic compound concentrations in bed-sediment core samples collected from selected sites at Brownlee Reservoir near Oxbow, Oregon, May 7-9, 2012.

12. Pesticide and herbicide concentrations in bed-sediment core samples collected from selected sites at Brownlee Reservoir near Oxbow, Oregon, May 7-9, 2012...........39

\section{Conversion Factors, Datums, and Abbreviations and Acronyms}

\section{Conversion Factors}

\begin{tabular}{|c|c|c|}
\hline Multiply & By & To obtain \\
\hline \multicolumn{3}{|c|}{ Length } \\
\hline centimeter (cm) & 0.3937 & inch (in.) \\
\hline meter (m) & 3.281 & foot (ft) \\
\hline kilometer (km) & 0.6214 & mile (mi) \\
\hline \multicolumn{3}{|c|}{ Volume } \\
\hline liter (L) & 33.82 & ounce, fluid (fl. oz) \\
\hline liter (L) & 61.02 & cubic inch $\left(\right.$ in $\left.^{3}\right)$ \\
\hline \multicolumn{3}{|c|}{ Mass } \\
\hline gram (g) & 0.03527 & ounce, avoirdupois (oz) \\
\hline kilogram (kg) & 2.205 & pound avoirdupois (lb) \\
\hline
\end{tabular}

Concentrations of chemical constituents in water are given in either milligrams or micrograms per liter $(\mathrm{mg} / \mathrm{L}$ or $\mu \mathrm{g} / \mathrm{L}$ ) or milligrams or micrograms per kilogram $(\mathrm{mg} / \mathrm{kg}$ or $\mu \mathrm{g} / \mathrm{kg})$. Units in nanograms per liter (ng/L) are approximately equivalent to parts per trillion (1012).

\section{Datums}

Vertical coordinate information is referenced to the National Geodetic Vertical Datum of 1929 (NGVD 29).

Horizontal coordinate information is referenced to the North American Datum of 1983 (NAD 83). 


\title{
Conversion Factors, Datums, and Abbreviations and Acronyms-Continued
}

\author{
Abbreviations and Acronyms \\ DO dissolved oxygen \\ IDE0 Idaho Department of Environmental Quality \\ IPC Idaho Power Company \\ HCC Hells Canyon Complex \\ MRL USGS Mercury Research Laboratory \\ ODEO Oregon Department of Environmental Quality \\ $\mathrm{PAH}$ polycyclic aromatic hydrocarbon \\ PCB polychlorinated biphenyl \\ PEC probable effect concentration \\ SVOC semi-volatile organic compound \\ TEC threshold effect concentration \\ TOC total organic carbon \\ USGS U.S. Geological Survey
}




\title{
Water Column and Bed-Sediment Core Samples Collected from Brownlee Reservoir near Oxbow, Oregon, 2012
}

\author{
By Ryan L. Fosness ${ }^{1}$, Jesse Naymik², Candice B. Hopkins' ${ }^{1}$, and John F. DeWild1
}

\section{Abstract}

The U.S. Geological Survey, in cooperation with Idaho Power Company, collected water-column and bed-sediment core samples from eight sites in Brownlee Reservoir near Oxbow, Oregon, during May 5-7, 2012. Water-column and bed-sediment core samples were collected at each of the eight sites and analyzed for total mercury and methylmercury. Additional bed-sediment core samples, collected from three of the eight sites, were analyzed for pesticides and other organic compounds, trace metals, and physical characteristics, such as particle size.

Total mercury and methylmercury were detected in each of the water column and bed-sediment core samples. Only 17 of the 417 unique pesticide and organic compounds were detected in bed-sediment core samples. Concentrations of most organic wastewater compounds detected in bed sediment were less than the reporting level. Trace metals detected were greater than the reporting level in all the bed-sediment core samples submitted for analysis. The particle size distribution of bed-sediment core samples was predominantly clay mixed with silt.

\section{Introduction}

Idaho Power Company (IPC) owns and operates Brownlee Dam, which forms Brownlee Reservoir (fig. 1), the farthest upstream and largest in area and volume within IPC's Hells Canyon Hydroelectric Project (Brownlee, Oxbow, and Hells Canyon Reservoirs), commonly referred to as the Hells Canyon Complex (HCC). Brownlee Dam was completed in May 1959, and along with the Oxbow and Hells Canyon Dams, effectively blocked the upstream migration of anadromous fish species (Idaho Power Company, 2003). A flow requirement management plan incorporated by IPC was adopted in 1991 to protect salmonid spawning areas downstream of the HCC. This plan called for constant streamflow releases from Brownlee Reservoir during the early part of the salmonid (including fall Chinook) spawning

${ }^{1}$ U.S. Geological Survey.

${ }^{2}$ Idaho Power Company. period in late October (Idaho Power Company, 1991). However, water temperatures in the Snake River downstream of the Hells Canyon Hydroelectric Project are warmer than the temperature criteria set for salmonid spawning by the Idaho Department of Environmental Quality (IDEQ) and Oregon Department of Environmental Quality (IDEQ and ODEQ; 2004). IPC is researching strategies to comply with the set temperature criteria during the salmonid spawning period. One potential strategy involves pumping hypolimnetic (cooler water from the deepest areas of the reservoir) into the Brownlee Dam powerhouse intake and downstream to the Snake River. A concern associated with accessing the deep, cool water is re-suspending and transporting potentially contaminated water and bed-sediment.

\section{Purpose and Scope}

This report documents the methods used to collect and analyze the water column and bed-sediment core samples from Brownlee Reservoir, and presents the results of the analyses. Characterization of the water column and bed-sediment chemistry in the reservoir provides data to better understand the potential effects of transporting potentially contaminated water from the hypolimnetic zone downstream.

\section{Description of the Study Area}

Brownlee Reservoir forms a part of the Idaho-Oregon border along the Snake River (ig. 1 ). The reservoir is about $92 \mathrm{~km}$ long (general flow direction is from south to north), less than $1 \mathrm{~km}$ wide, and reaches depths exceeding $90 \mathrm{~m}$ near Brownlee Dam. The reservoir is defined by steep margins and a well-defined pre-impoundment thalweg. The mean pool elevation for Brownlee Reservoir for water years 2010-11 ranged from 614 to $633 \mathrm{~m}$ above the NGVD 29 datum. Typically, IPC draws the reservoir down (about 12-18 m during 2010 and 2011) in the early spring to create storage capacity for snowmelt runoff. The Snake River is the main contributor of streamflow to Brownlee Reservoir, but the Burnt and Powder Rivers, and Dennett, Sturgill, and Brownlee Creeks discharge directly to the reservoir (fig. 1). Wood and Etheridge (2011) provide a more comprehensive description of land use, drainage area, and other characteristics of the Snake River watershed upstream of Brownlee Reservoir. 


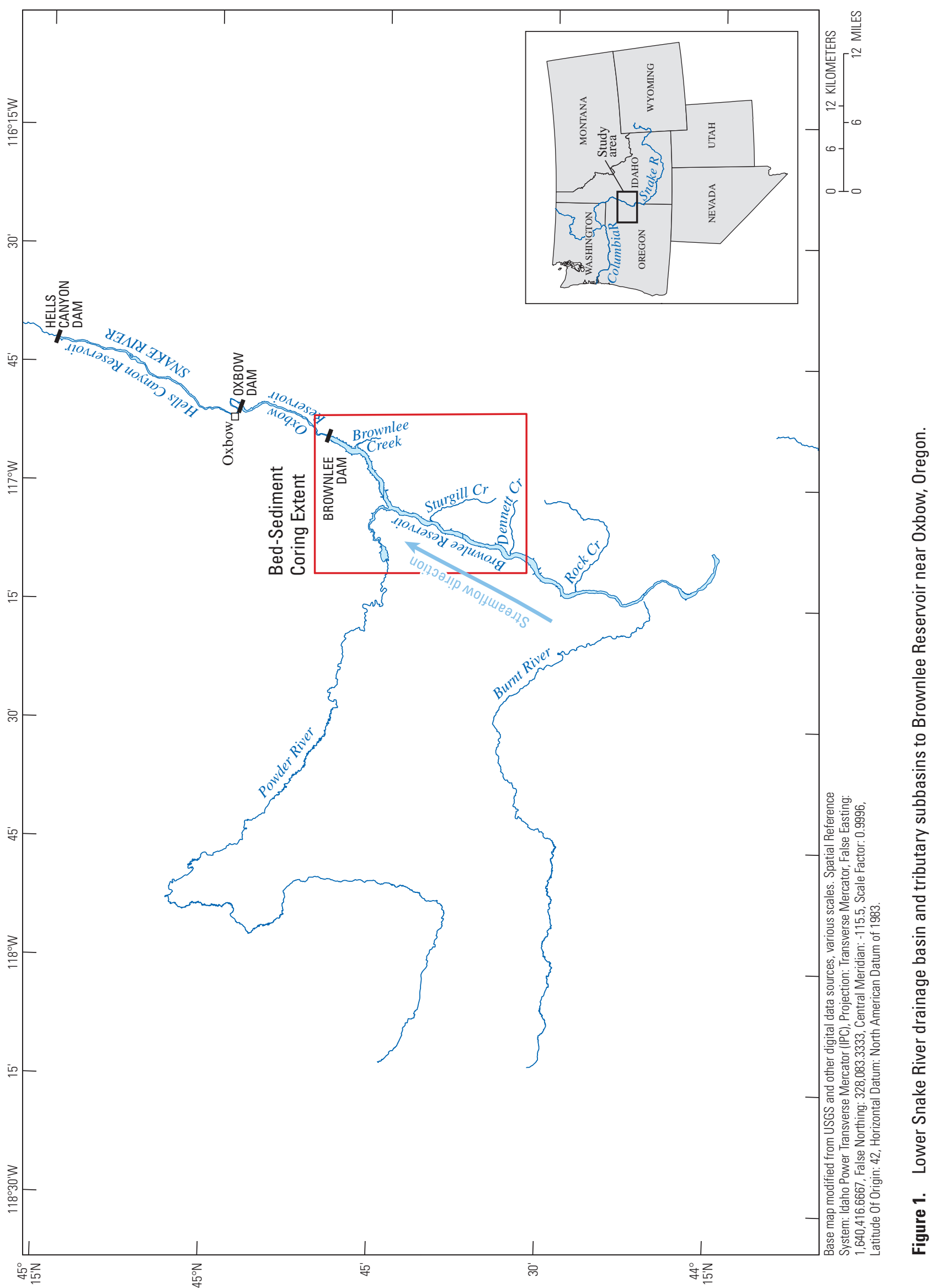




\section{Previous Investigations}

Although numerous water-quality and sediment studies have been completed in Brownlee Reservoir, most previous investigations have focused on specific compounds and have not included the wide array of constituents that may be present in the water column and bed-sediment.

In 1998, the U.S. Geological Survey (USGS), in cooperation with IPC, collected bed-sediment and fish-tissue samples at two sites in an upstream part of Brownlee Reservoir near the Burnt River and Dennett Creek. The sediment samples were collected and analyzed for organochlorine compounds and trace elements. Bed-sediment samples collected at the Burnt River contained the largest concentration of detected organochlorine compounds (Dacthal, p,p'-DDD, p,p'-DDE, p,p'-DDT, and Hexachlorobenzene) in the Snake River Basin. However, the concentrations of the organochlorine compounds were significantly reduced at the downstream site near Dennett Creek where the only detected compounds were p,p'-DDD and p,p'- DDE. Concentrations of trace metals including arsenic, cadmium, chromium, copper, nickel, and zinc in the bed sediment collected near Dennett Creek were the largest in the Snake River Basin. The concentration of the trace elements generally increased from the site at Burnt River to the site near Dennett Creek (Clark and Maret, 1998).

In a follow-up study done in 1998 and 1999, CH2M HILL (2000) did sediment coring throughout Brownlee Reservoir, including sites near those sampled by Clark and Maret (1998). The objective of the CH2M HILL study was to determine the physical and mineralogical characteristics of sediment along the thalweg of the channel through Brownlee Reservoir. As part of the study, CH2M HILL analyzed the bed sediment for selected organochlorine and trace elements. Generally, organochlorine and trace element concentrations (including total mercury) in the bed sediment increased in a northerly direction toward Brownlee Dam (CH2M HILL, 2000). Physical and mineralogical results from the study provided insight into the sedimentation patterns in the reservoir; silt and clay-sized-sediment accounted for more than 99 percent of the total particle-size distribution near Brownlee Dam.

In June and September 2006, Brandt (2007) collected water samples upstream and downstream of Brownlee Reservoir to determine the concentration and load of total mercury into and out of Brownlee Reservoir. The results were used to estimate a mass balance for total mercury and to identify the major sources of mercury to Brownlee
Reservoir. Findings from the study indicated relatively low concentrations and loadings of total mercury to the reservoir. However, the reservoir seemed to be acting as a mercury sink; less than 50 percent of the total mercury entering Brownlee Reservoir was transported through the reservoir.

In October of 2010 and 2011, Harrison and others (2012) collected water samples from the hypolimnion and discharge waters of Brownlee Reservoir, and analyzed the samples for selected organic and inorganic compounds (including mercury). Seventeen inorganic constituents were analyzed in 2010, and 470 organic constituents were analyzed in 2011 along with total mercury and methylmercury. Of the 470 organic constituents analyzed in 2011, only 7 pesticides, including the isomers or degradates of pesticides, were detected in the water column. Other organic compounds, including semi-volatile organic compounds (SVOCs), individual polycyclic aromatic hydrocarbons (PAHs), polychlorinated biphenyls (PCBs), and dioxins, were detected at levels less than the laboratory limits of quantification. All concentrations were less than the aquatic-life criteria and benchmarks established by the U.S. Environmental Protection Agency (EPA) (Stephan and others, 1985). However, fish consumption advisories based on mercury are in place for Brownlee Reservoir, and the relatively high methylmercury concentrations detected in the hypolimnion of Brownlee Reservoir (2.5-2.9 ng/L) were noted by Harrison and others (2012) as a human health concern.

\section{Methods}

\section{Sampling Methods}

Water-column sampling and bed-sediment coring were done during the week of May 7-11, 2012. Field personnel from the USGS Idaho Water Science Center in Boise and the USGS Mercury Research Laboratory (MRL) in Madison, Wisconsin collected samples from eight sites (fig. 2, table 1) to provide a spatial representation of the northern half of the reservoir. Sites 1-3 were slightly upstream of the deepest part of the reservoir near Brownlee Dam. Sites 4-8 were located coincident with the confluences of reservoir tributaries. All of the sites were within the pre-impoundment thalweg to target the zone of maximum sediment accumulation of fine-grained (less than $0.063 \mathrm{~mm}$ ) bed sediment (van Metre and others, 2004). High-resolution bathymetry provided by IPC was used to identify the pre-impoundment thalweg at each of the sites. 


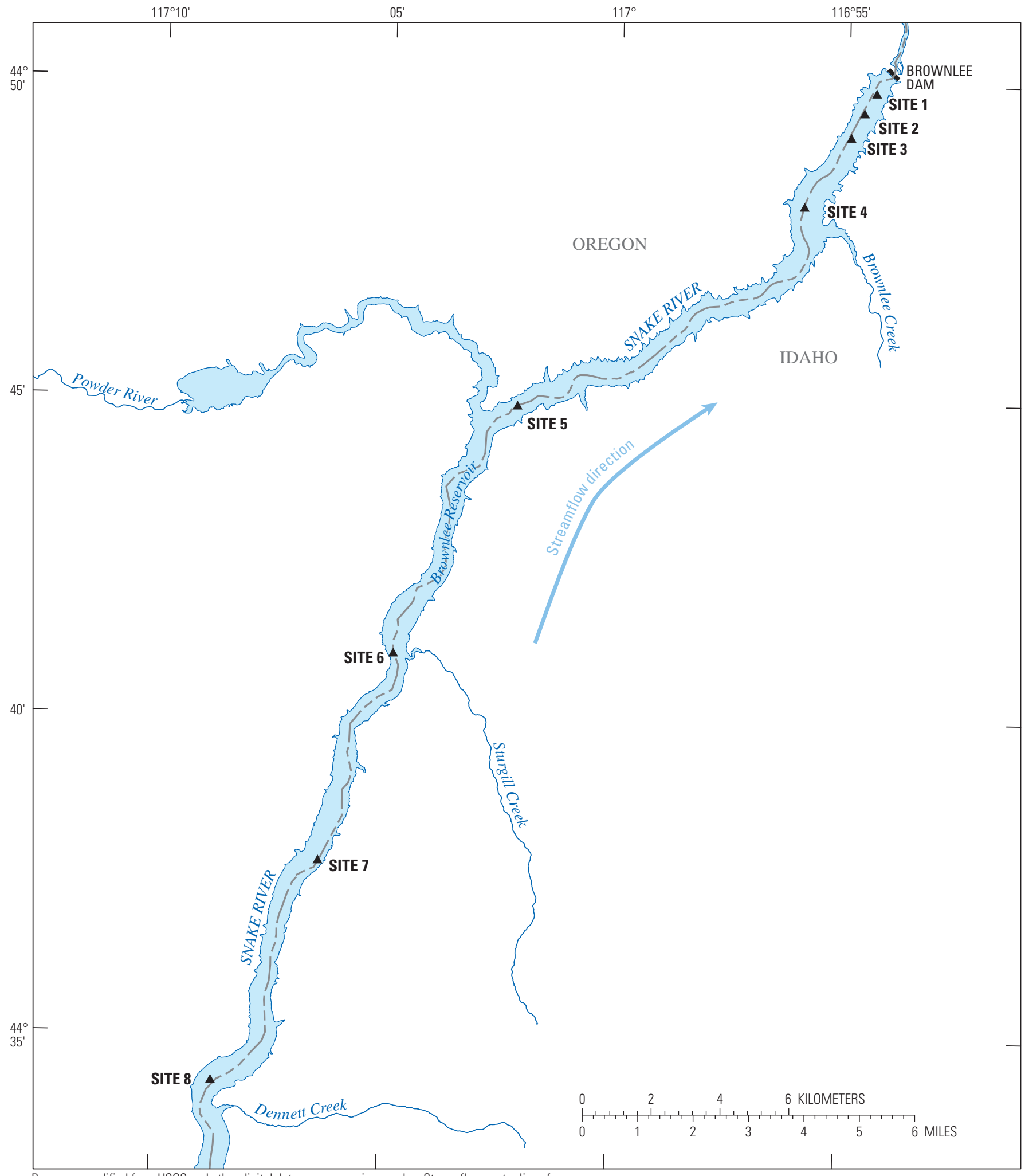

Base map modified from USGS and other digital data sources, various scales. Streamflow vector lines from National Hydrography Dataset. Spatial Reference System: Idaho Power Transverse Mercator (IPC), Projection:

Transverse Mercator, False Easting: 1,640,416.6667, False Northing: 328,083.3333, Central Meridian: -115.5

Scale Factor: 0.9996, Latitude Of Origin: 42, Horizontal Datum: North American Datum of 1983.

Figure 2. Locations where water-column samples and bed-sediment core samples were collected from Brownlee Reservoir near Oxbow, Oregon, May 7-9, 2012. 
Table 1. Description of sites and number of water-column and bed-sediment core samples collected from Brownlee Reservoir near Oxbow, Oregon, May 7-9, 2012.

[NWIS site: All sites are in Snake River upstream of Brownlee Dam, Idaho. River mile designation: Designations are commonly referenced locations, so a conversion to kilometers was not made or recommended. Online data can be viewed at http://waterdata.usgs.gov/nwis/ inventory by entering the National Water Information System (NWIS) site No. for each site using a multiple site numbers search criteria. - , no sample]

\begin{tabular}{|c|c|c|c|c|c|c|c|}
\hline \multirow[b]{2}{*}{$\begin{array}{c}\text { NWIS } \\
\text { site name }\end{array}$} & \multirow[b]{2}{*}{$\begin{array}{l}\text { NWIS } \\
\text { site No. }\end{array}$} & \multirow[b]{2}{*}{$\begin{array}{l}\text { River mile } \\
\text { designation }\end{array}$} & \multirow[b]{2}{*}{$\begin{array}{l}\text { Water-column } \\
\text { mercury samples }\end{array}$} & \multicolumn{4}{|c|}{ Bed-sediment cores } \\
\hline & & & & $\begin{array}{c}\text { Mercury } \\
\text { (total and } \\
\text { methylmercury) }\end{array}$ & $\begin{array}{c}\text { Organics } \\
\text { and } \\
\text { trace elements }\end{array}$ & $\begin{array}{c}\text { Description } \\
\text { and } \\
\text { particle size }\end{array}$ & Replicates \\
\hline Site 1 & 444954116542400 & 285.1 & 3 & 1 & 4 & 1 & 2 \\
\hline Site 2 & 444935116544000 & 285.5 & 3 & 1 & - & - & 2 \\
\hline Site 3 & 444912116545700 & 286.0 & 3 & 1 & - & - & 2 \\
\hline Site 4 & 444807116555700 & 287.6 & 3 & 1 & - & - & 2 \\
\hline Site 5 & 444455117021200 & 295.1 & 3 & 1 & 4 & 1 & 2 \\
\hline Site 6 & 444101117045000 & 300.7 & 3 & 1 & - & - & 2 \\
\hline Site 7 & 443745117062500 & 305.1 & 3 & 1 & - & - & 2 \\
\hline Site 8 & 443416117084000 & 310.0 & 3 & 1 & 4 & 1 & 2 \\
\hline
\end{tabular}

\section{Water Column Profiles}

Before sampling, water column profiles of temperature, dissolved oxygen (DO), and specific conductance were collected at each site using a Sea-Bird Electronics, Inc. SeaCAT Profiler CTD SBE-19plus (SEACAT) (fig. 3). The water column profiles were used to understand the stratification of the reservoir and to identify specific depths from which to collect water samples for analysis of total mercury and methylmercury. The SEACAT is designed to drift slowly (approximately $0.5 \mathrm{~m}$ per second) downward through the water column, continuously collecting data four times per second. Post-processed readings provided data at intervals of about $0.5 \mathrm{~m}$ within the water column. The SEACAT was calibrated by the manufacturer prior to the field work, and was verified each day using an independent probe (Hydrolab ${ }^{\circledR}$ multiprobe).

\section{Water-Column Samples}

Three zones were targeted for water-column sampling based on the information collected from the water column profiles. Samples were collected at about $0.5 \mathrm{~m}$ below the water surface in the upper part of the epilimnion (warmer upper zone), near the bottom of the metalimnion (middle zone) where the temperature and DO sharply decreased, and in the hypolimnion (bottom zone) slightly above the reservoir bed. Water column samples were collected at sites 1-8 for mercury analysis using the methods described in Lewis and Brigham (2004). A horizontally oriented Niskin point-sampler (fig. 4) was used to collect samples from each of the three targeted zones in the water column. The pre-cleaned Niskin sampler was lowered in the "open" position, and a triggering device was used to collect the sample at the desired depth. Each water sample was transferred to a separate pre-cleaned container and stored on ice. 


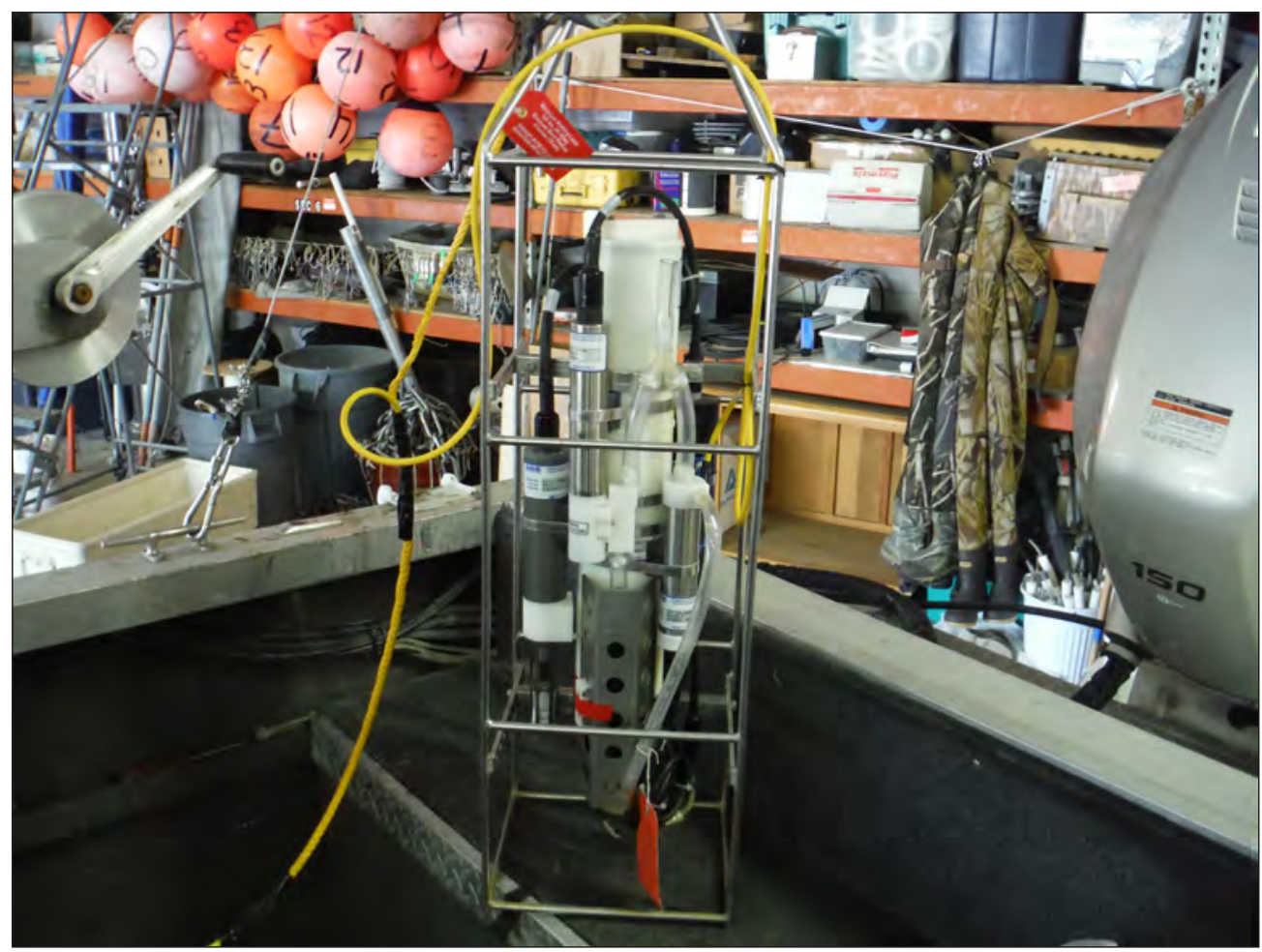

Figure 3. Sea-Bird Electronics, Inc. SEACAT Profiler CTD SBE-19plus, used to collect water column profiles of temperature, dissolved oxygen, and specific conductance in Brownlee Reservoir near Oxbow, Oregon, May 7-9, 2012.

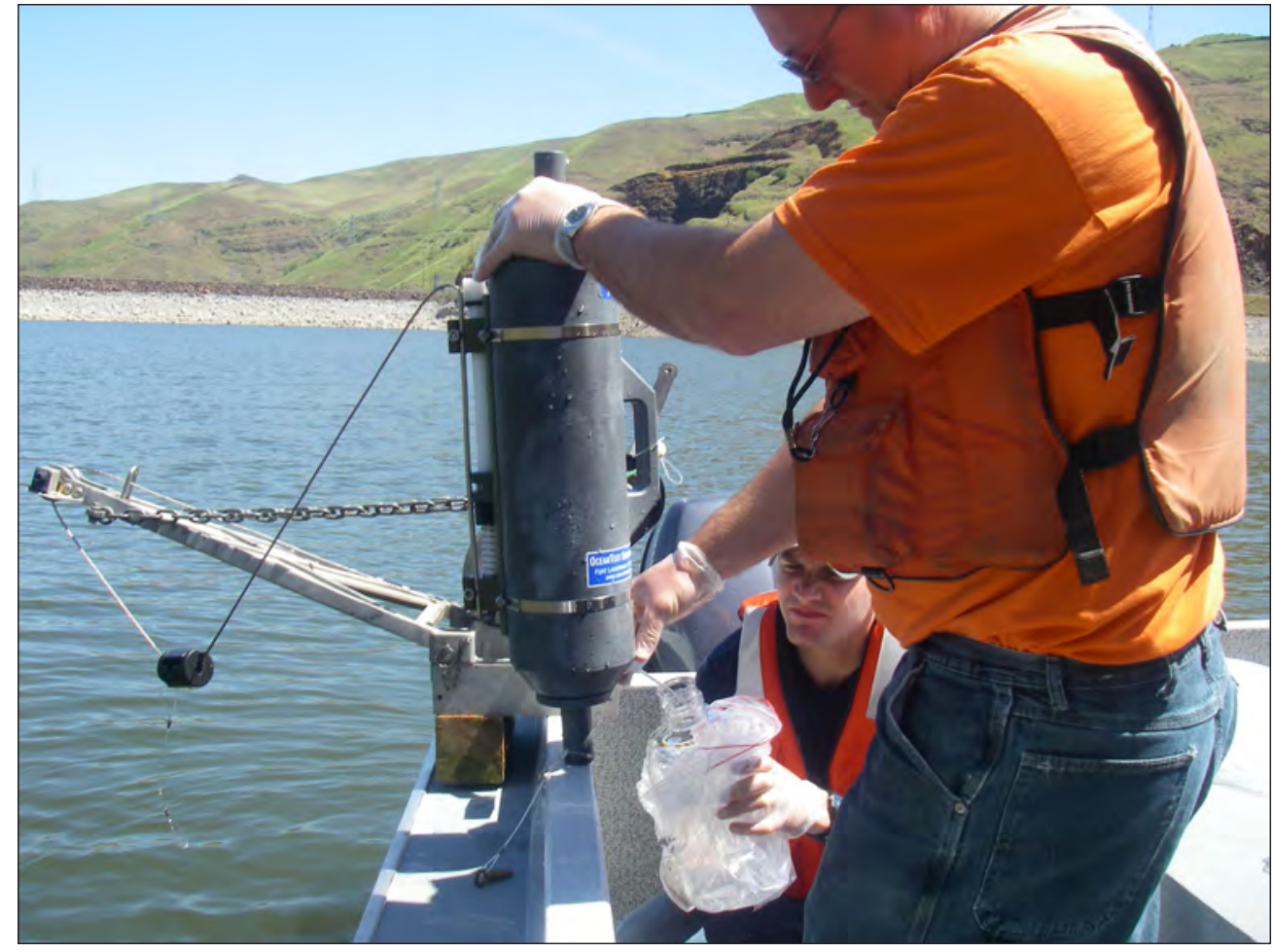

Figure 4. Niskin point-sampler used to collect water column samples in Brownlee Reservoir near Oxbow, Oregon, May 7-9, 2012. 


\section{Bed-Sediment Core Samples}

Bed-sediment core samples were collected at each of the eight sites for analysis of total mercury and methylmercury. Additional bed-sediment core samples were collected at sites 1,5 , and 8 for analysis of organics and trace metals, description of particle size, and replicates (table 1).

A lightweight gravity core sampler was determined to be the most appropriate device for the bed-sediment coring. Two types of gravity core samplers were used. The first type was a lightweight $5.1 \mathrm{~cm}$ (inside diameter) Ballchek ${ }^{\mathrm{TM}}$ Corer (fig. 5) with an automatic check valve and three fins for stabilization. The Ballchek ${ }^{\mathrm{TM}}$ valve allowed water to flow through the core barrel on descent and prevented disturbance to the surficial bed-sediment upon collection. The second core sampler was a K-B $\mathrm{B}^{\mathrm{TM}}$ Corer, which is a heavier version of the Ballchek ${ }^{\mathrm{TM}}$ Corer. The K-B ${ }^{\text {TM }}$ Corer was used only at site 8 where the bed sediment was more consolidated. A 5.1-cm-diameter, 91.4-cm-long stainless-steel core barrel was threaded to the selected core sampler, and a plastic (cellulose acetate butyrate) liner was placed in the core barrel. The bed-sediment was cohesive and easily retained in the core barrel, negating the need for a core catcher at the bottom of the barrel. A nose piece made of Lexan ${ }^{\circledR}$ was attached to the bottom of the core barrel to hold the core liner in place and to prevent the stainless steel core barrel from contacting the sediment. A hand-winch was used to lower and raise the core barrel from the coring vessel. After each core was captured and brought to the surface, the liner was removed from the core barrel, and was capped, labeled, measured, and photographed (fig. 6). After all the cores were collected at the site, they were transferred to shore for subsampling. All equipment used to collect the bed-sediment core samples was decontaminated prior to sampling using methods described in Shelton and Capel (1994) and in chapter 8 of the USGS National Field Manual (Radtke, 2005).

\section{Underwater Videography}

The physical composition of the bed sediment collected from Brownlee Reservoir caused little resistance to core penetration. To ensure that a consistent core length was collected and that disturbance to the sample was minimized, an underwater video camera was used to monitor the core-barrel penetration. The camera was mounted above the bottom of the core barrel and oriented to look downward (fig. 7A). The transmitted video (fig. 7B) allowed field personnel to monitor the position of the core barrel as it was lowered into the sediment to obtain a consistent core length of about $75 \mathrm{~cm}$.

\section{Sample Processing}

Following collection, water column and bed-sediment core samples were transferred to a mobile laboratory on shore and prepared for subsampling. Water samples were

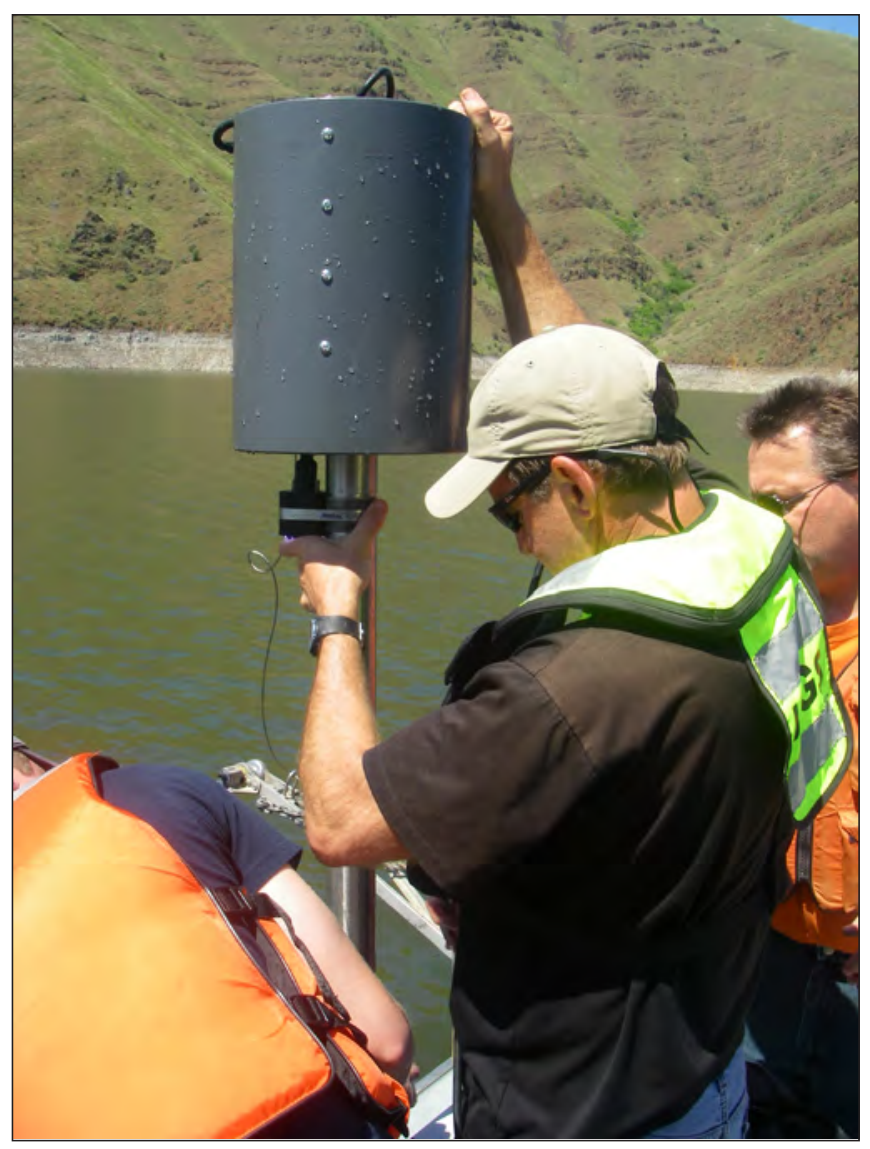

Figure 5. Ballchek ${ }^{\mathrm{TM}}$ bed-sediment core sampler used in Brownlee Reservoir near Oxbow, Oregon, May 7-9, 2012.

filtered in the field prior to shipment. A description of the processing, preservation, storage, and shipment of the samples for mercury analysis is available in Lewis and Brigham (2004). Bed-sediment cores were subsampled and prepared for mercury analysis using methods described by Lewis and Brigham (2004) and by Radtke (2005). A core pusher was used to extrude each core (fig. 8). The minimum core length for mercury analysis was $30 \mathrm{~cm}$; the subsampling interval was based on sediment layering, but generally was $2 \mathrm{~cm}$ or less. From each core, 8 to 10 subsamples were taken. A minimum of $2 \mathrm{~g}$ of sediment (dry weight) were required from each subsample for mercury analysis.

Bed-sediment cores from sites 1,5 , and 8 were subsampled for pesticides and organic compounds, trace metals, and physical characteristics. Four cores were collected at each of the three sites to provide a sufficient quantity of sediment for laboratory analyses. A core pusher was used to extrude each core into a top sample designated "a" $(0-30 \mathrm{~cm})$, and a bottom sample designated "b" (30-75 cm). The respective top and bottom samples from each of the four cores were homogenized into a single top and bottom sample prior to subsampling for laboratory analysis. This was necessary to ensure enough material was available for all laboratory analyses and to maintain consistency between the sites. 

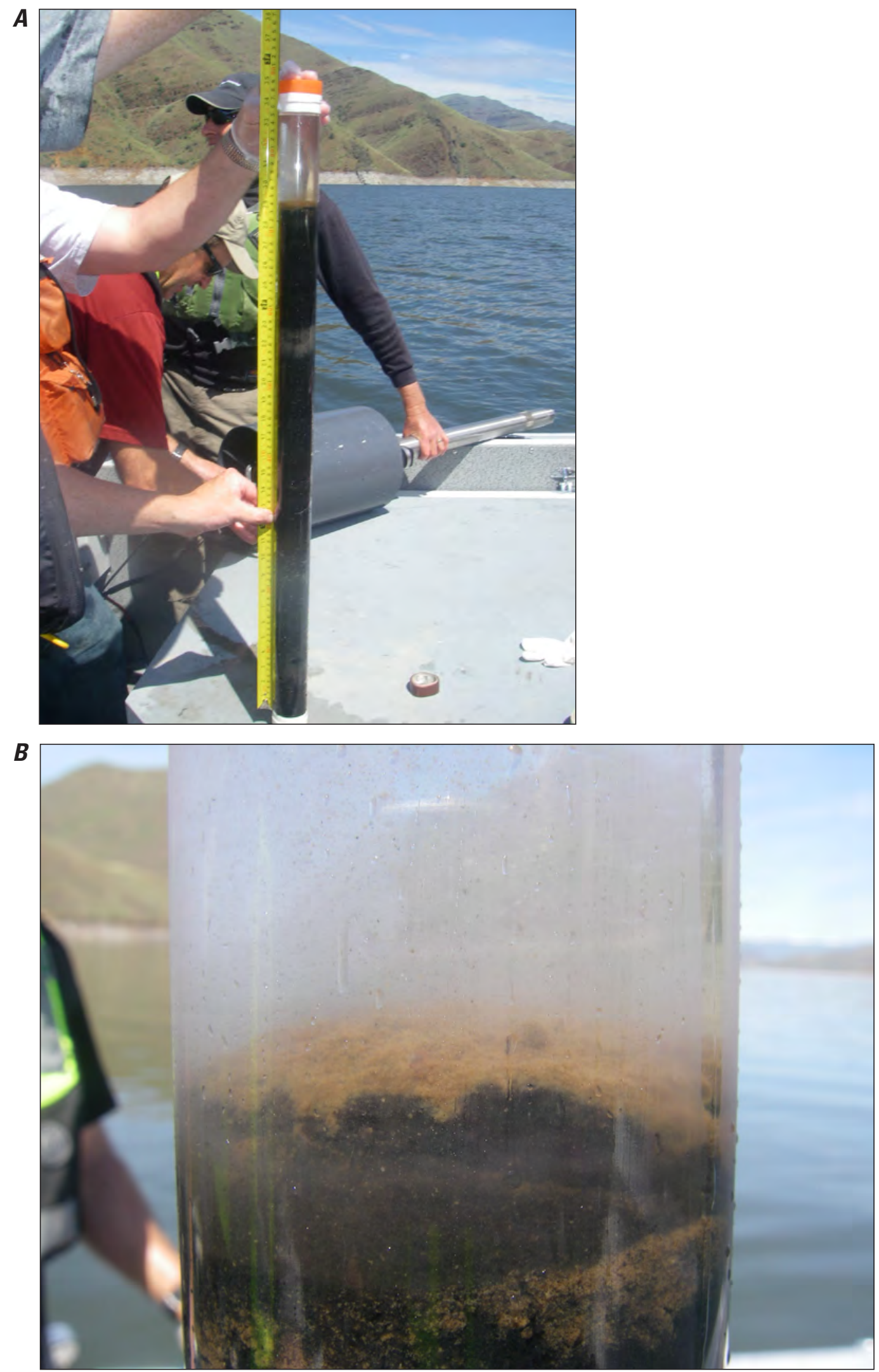

Figure 6. Typical $(A)$ core recovery and $(B)$ close-up of organic material on top of core sample collected from site 2 at Brownlee Reservoir near Oxbow, Oregon, May 7-9, 2012. 


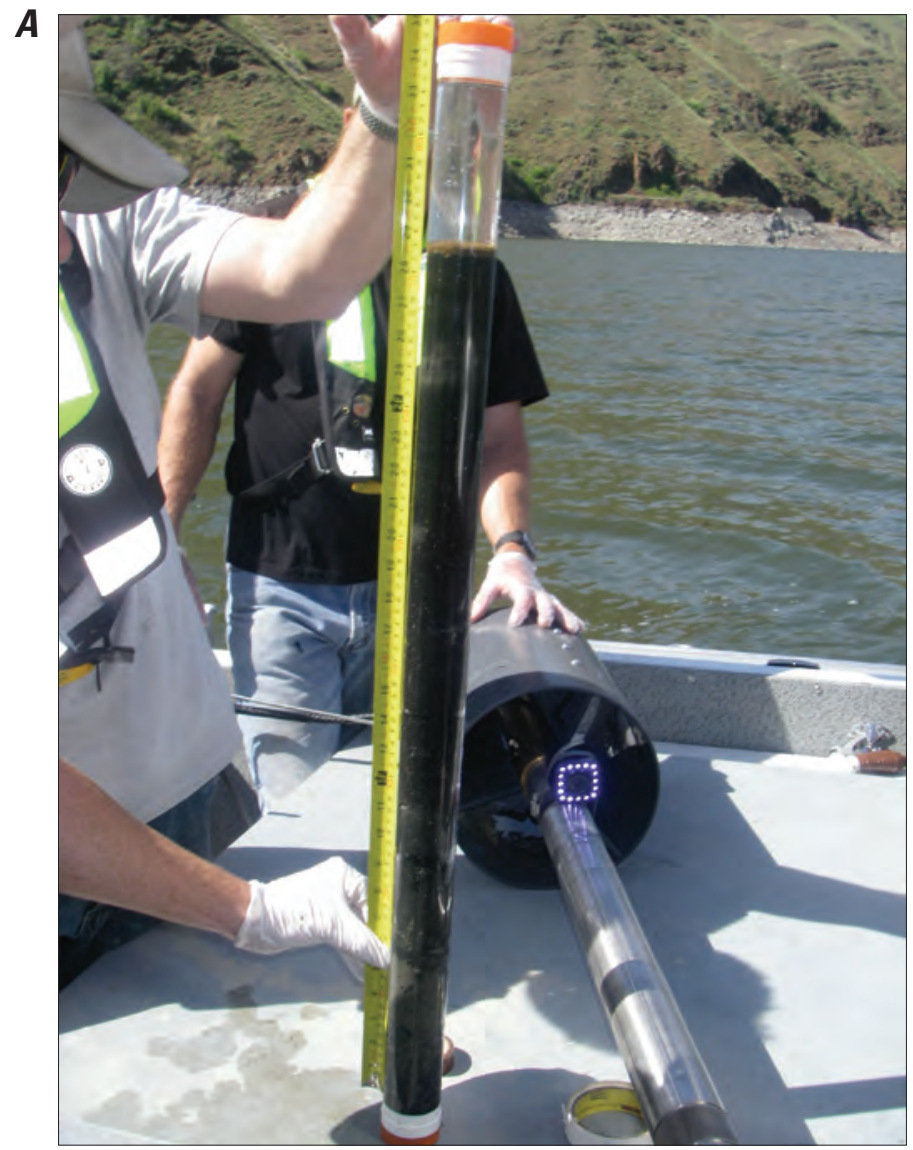

$\boldsymbol{B}$

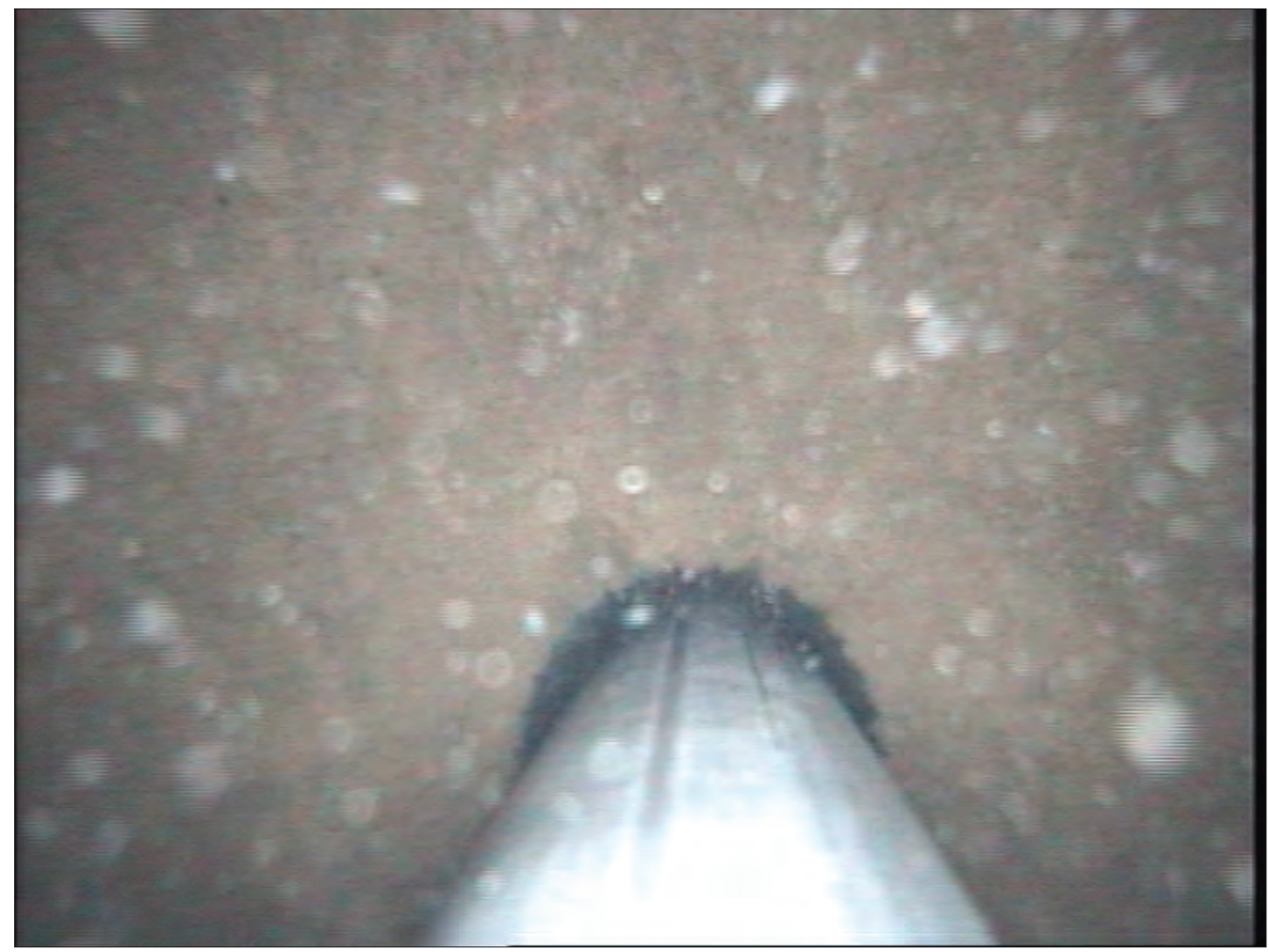

Figure 7. Underwater video camera system used to assist with sediment coring showing $(A)$ components of camera mounted on core barrel, and $(B)$ example image of collection of bed-sediment core sample in Brownlee Reservoir, Oregon, May 7-9, 2012. 


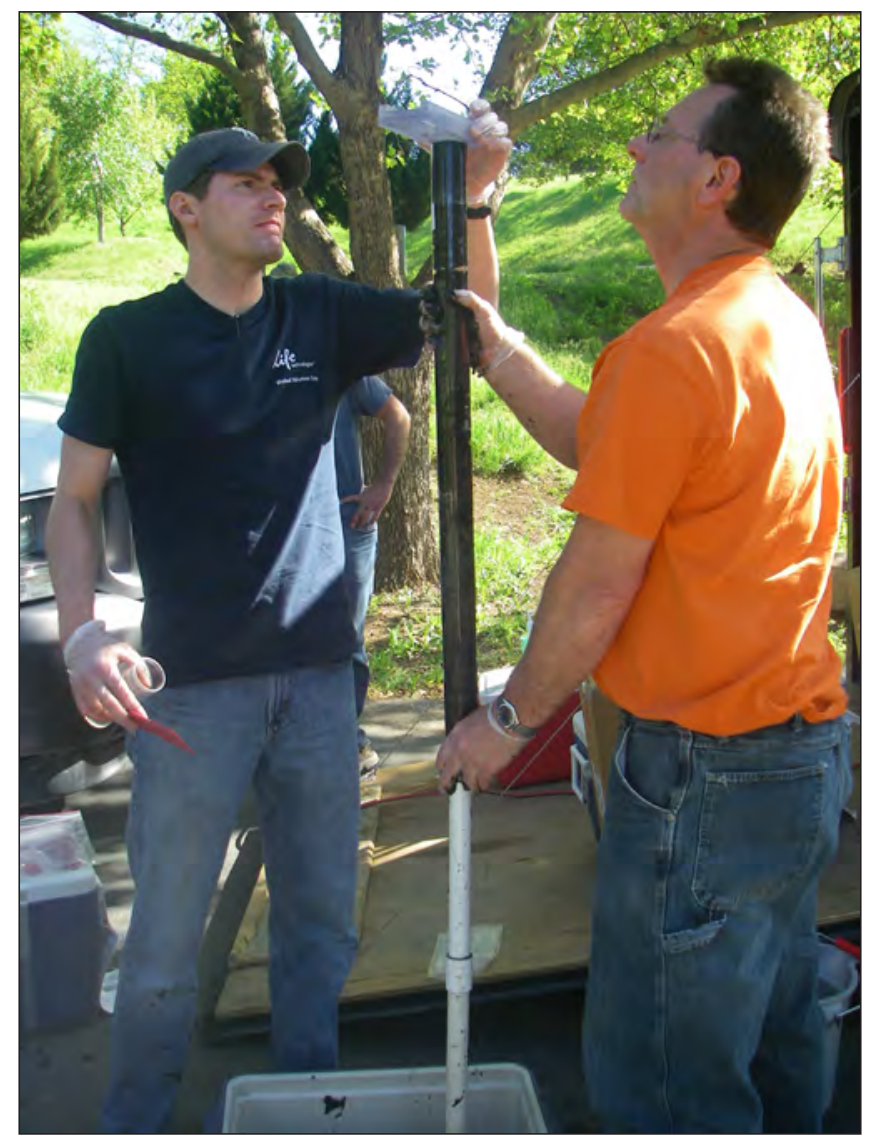

Figure 8. Extraction process used to subsample bed-sediment cores collected from Brownlee Reservoir near Oxbow, Oregon, May 7-9, 2012.

\section{Laboratory Methods}

Water column and bed-sediment core samples were analyzed at seven laboratories based on the constituents of interest (table 2). Water column and bed-sediment core samples were analyzed for total mercury and methylmercury at the MRL. Core samples were analyzed for selected pesticides, organic compounds, trace metals, and physical characteristics at the University of Idaho-Analytical Sciences Laboratory (UI-ASL), Pace Analytical Services, Inc. (Pace), Pacific Agriculture Laboratory (PacAg), USGS National Water Quality Laboratory (NWQL), USGS Pesticide Fate Research Group Production Laboratory (PFRG), and the USGS Kansas Water Science Center Organic Geochemistry Research Laboratory (OGRL).

Laboratory methods and abbreviated descriptions of the techniques used to analyze samples are described in table 2. A listing of all EPA methods and documentation is available at ALS Environmental (2013). A list of standard methods is available at American Public Health Association
(2006). American Society for Testing and Materials (ASTM) methodology is available at American Society for Testing and Materials (2013).

\section{Mercury in Water and Sediment}

The MRL analyzed water column and bed-sediment core samples using methods described in table 2. Water samples were analyzed for filtered and particulate total mercury, filtered and particulate methylmercury, and dissolved organic carbon. At each of the 8 sites, 8 to 10 subsamples of bed sediment from cores were collected and analyzed for total mercury, methylmercury, percentage of dry weight, and percentage of loss on ignition. Additional information about laboratory procedures can be accessed at U.S. Geological Survey (2013).

\section{Pesticides and Other Organic Compounds}

Bed-sediment core samples were analyzed for pesticides and organic compounds using the methods listed in table 2. The UI-ASL in Moscow, Idaho, analyzed bed-sediment core samples for selected herbicides and carbamate insecticides using modified EPA methods. The Pace Analytical Laboratory in Minneapolis, Minnesota, followed EPA methods to analyze bed-sediment core samples for SVOCs, PAHs, organochlorine pesticides, PCBs, chlorinated herbicides, and dioxin. The PacAg Laboratory in Portland, Oregon, followed EPA methods to analyze bed-sediment core samples for halogenated pesticides, organophosphorus and organosulfur pesticides, phenylurea herbicides, and carbamate insecticides. The PacAg laboratory also processed bed-sediment core samples for the herbicide glyphosate and its breakdown product aminomethylphosphonic acid (AMPA). The NWQL in Lakewood, Colorado, analyzed bed-sediment core samples for wastewater compounds using methods listed in table 2. The PFRG laboratory in Sacramento, California, analyzed bed-sediment core samples for current-use pesticides, their degradation products, and organochlorine insecticides. The Kansas Water Science Center Organic Geochemistry Research Laboratory in Lawrence, Kansas, analyzed bed-sediment core samples for glyphosate, AMPA, and the herbicide glufosinate.

\section{Physical Characteristics and Trace Metals}

Bed-sediment core samples were analyzed for physical characteristics and trace metals using methods listed in table 2. The Pace Analytical Laboratory in Minneapolis, Minn., analyzed physical characteristics (total solids, total organic carbon (TOC), grain size, $\mathrm{pH}$, and redox state) using EPA methods, standard methods, and ASTM methods. The NWQL in Lakewood, Colo., analyzed bed-sediment core samples for trace metals in sediment. 
Methods

11

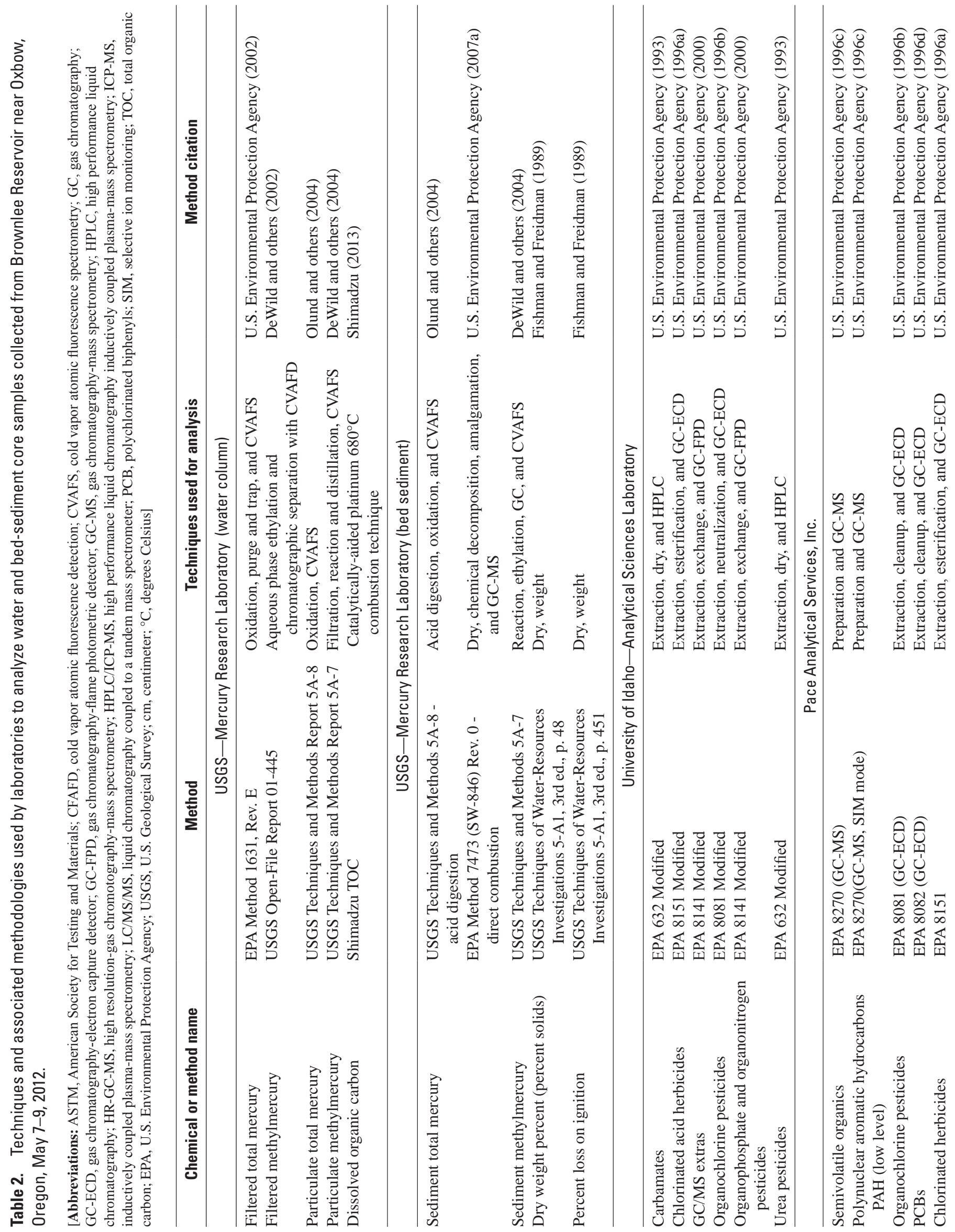




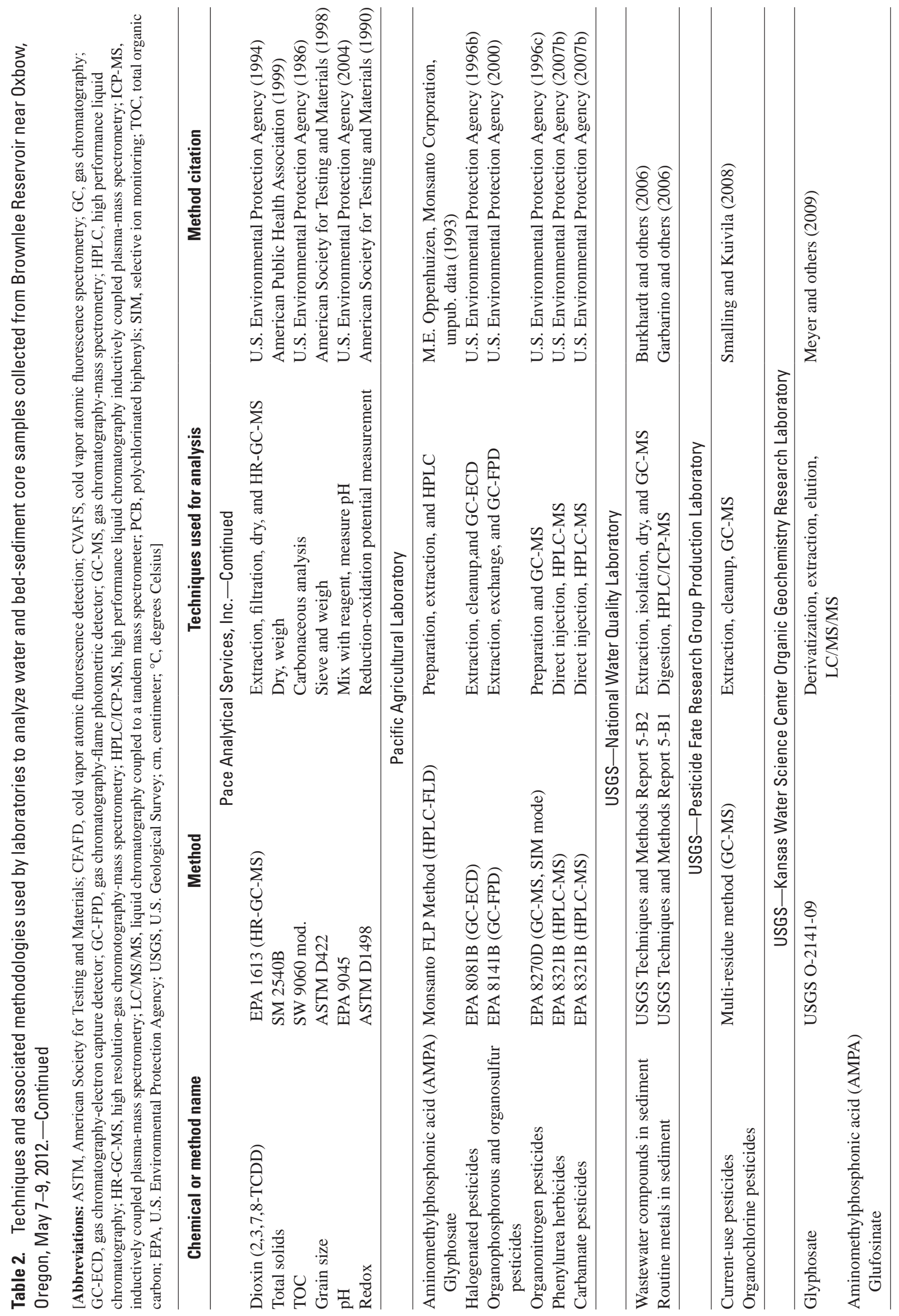




\section{Quality Assurance and Quality Control}

This study followed the USGS Idaho Water Science Center's quality-assurance plan for the collection of water-quality samples (Mark Hardy, U.S. Geological Survey, written commun., 2008). Quality-control and environmental samples were collected. Quality control for bed-sediment core samples included one split field replicate sample for each laboratory analysis. The split replicate samples from the laboratory were reviewed to ensure no major discrepancies between the environmental and split replicate samples. Sample blinds or blank samples were not submitted as part of this study. However, all laboratory methods and internal quality-control standards for each laboratory included in this study were reviewed and approved by the USGS. Two core samples from each of the 8 sites (16 samples) were collected concurrently as replicate core samples, but were not submitted for analysis. The replicate core samples were frozen immediately after being transferred to the on-site sample preparation area and were subsequently transferred to an IPC storage facility for long-term storage.

\section{Water Column and Sediment Core Samples}

\section{Total Mercury and Methylmercury in Water and Sediment}

The MRL analyzed water samples for filtered and particulate total mercury, filtered and particulate methylmercury, and dissolved organic carbon (table 3). Filtered total mercury concentrations in water ranged from 0.38 to $1.3 \mathrm{ng} / \mathrm{L}$. Filtered methylmercury concentrations generally increased with depth and were less than $0.13 \mathrm{ng} / \mathrm{L}$, with the exception of the outlier at site $8(0.61 \mathrm{ng} / \mathrm{L})$. Particulate total mercury concentrations also increased with depth and ranged from 0.287 to $1.89 \mathrm{ng} / \mathrm{L}$. Particulate methylmercury concentrations ranged from 0.027 to $0.312 \mathrm{ng} / \mathrm{L}$. Dissolved organic carbon concentrations ranged from 1.8 to $2.8 \mathrm{mg} / \mathrm{L}$.

Total mercury and methylmercury were detected in all bed-sediment core samples (table 4). Total mercury concentrations in sediment ranged from 51.4 to $112 \mu \mathrm{g} / \mathrm{kg}$. Methylmercury concentrations ranged from 0.36 to $18 \mu \mathrm{g} / \mathrm{kg}$, with the highest concentrations occurring near the sediment-water interface. Percentage of dry weight from bed-sediment core samples ranged from 5.52 to 31.53 percent. The measured percentage of loss on ignition ranged from 6.68 to 17.28 percent.

\section{Pesticides and Organic Compounds}

Bed-sediment core samples collected at sites 1,5 , and 8 were analyzed for 417 pesticides and other organic compounds. Concentrations of pesticides and other organic compounds are listed by the laboratory in which they were analyzed.

\section{University of Idaho-Analytical Sciences Laboratory}

Bed-sediment core samples from sites 1, 5, and 8 were analyzed at UI-ASL for selected herbicides and carbamate pesticides (table 5). The carbamate pesticide baygon (propoxur) was detected in cores $5 \mathrm{~b}, 8 \mathrm{a}$, and $8 \mathrm{~b}$ at concentrations of $6.1,6.1$, and $7.3 \mu \mathrm{g} / \mathrm{kg}$, respectively. The chlorinated acid herbicide 2,4-dichlorobenzoic acid was present at concentrations less than the reporting level of $10 \mu \mathrm{g} / \mathrm{kg}$ in core samples $1 \mathrm{a}, 1 \mathrm{~b}, 5 \mathrm{a}, 5 \mathrm{~b}$, and $8 \mathrm{a}$, and the chlorinated acid herbicide pentachlorophenol was less than the reporting level of $8 \mu \mathrm{g} / \mathrm{kg}$ in core $8 \mathrm{~b}$. The organochlorine pesticide compound dichlorodiphenyldichloroethylene (DDE), a breakdown product of dichlorodiphenyltrichloroethane (DDT), was less than the reporting level of $3 \mu \mathrm{g} / \mathrm{kg}$ in cores $5 \mathrm{~b}, 8 \mathrm{a}$, and $8 \mathrm{~b}$. The pesticide prometon was less than the reporting level of $5 \mu \mathrm{g} / \mathrm{kg}$ in cores $5 \mathrm{~b}, 8 \mathrm{a}$, and $8 \mathrm{~b}$. No urea pesticides were detected in the bed-sediment core samples.

\section{Pace Analytical Services Laboratory}

Bed-sediment core samples at sites 1, 5, and 8 were analyzed by the Pace Analytical Services Laboratory for SVOCs, PAHs, organochlorine pesticides, PCBs, chlorinated herbicides, and dioxin. SVOCs, chlorinated herbicides, or PAHs were not detected (table 11; at back of report). The breakdown product 4,4'-DDE was the only organochlorine pesticide detected; however, the concentrations were less than the adjusted reporting limit (but greater than the detection limit) in every sample analyzed. Cores 5a, 8a, and 8b were not analyzed for PCBs due to miscommunications with the laboratory, but PCBs were not detected in samples collected from the three remaining core samples (1a, $1 b$, and $5 b$ ). Chlorinated herbicides were analyzed for bed-sediment core samples collected at site 1 due to a miscommunication at the laboratory; no chlorinated herbicides were detected in either of the cores collected at site 1 . Dioxin was not detected in any of the bed-sediment core samples. 
Table 3. Total mercury, methylmercury, and dissolved organic carbon concentrations in water-column samples collected from Brownlee Reservoir near Oxbow, Oregon, May 7-9, 2012.

[Samples analyzed at U.S. Geological Survey Mercury Research Laboratory according to laboratory methodologies listed in table 2. Abbreviations: m, meter; ng/L, nanogram per liter; mg/L, milligram per liter; USGS, U.S. Geological Survey; -, no data available]

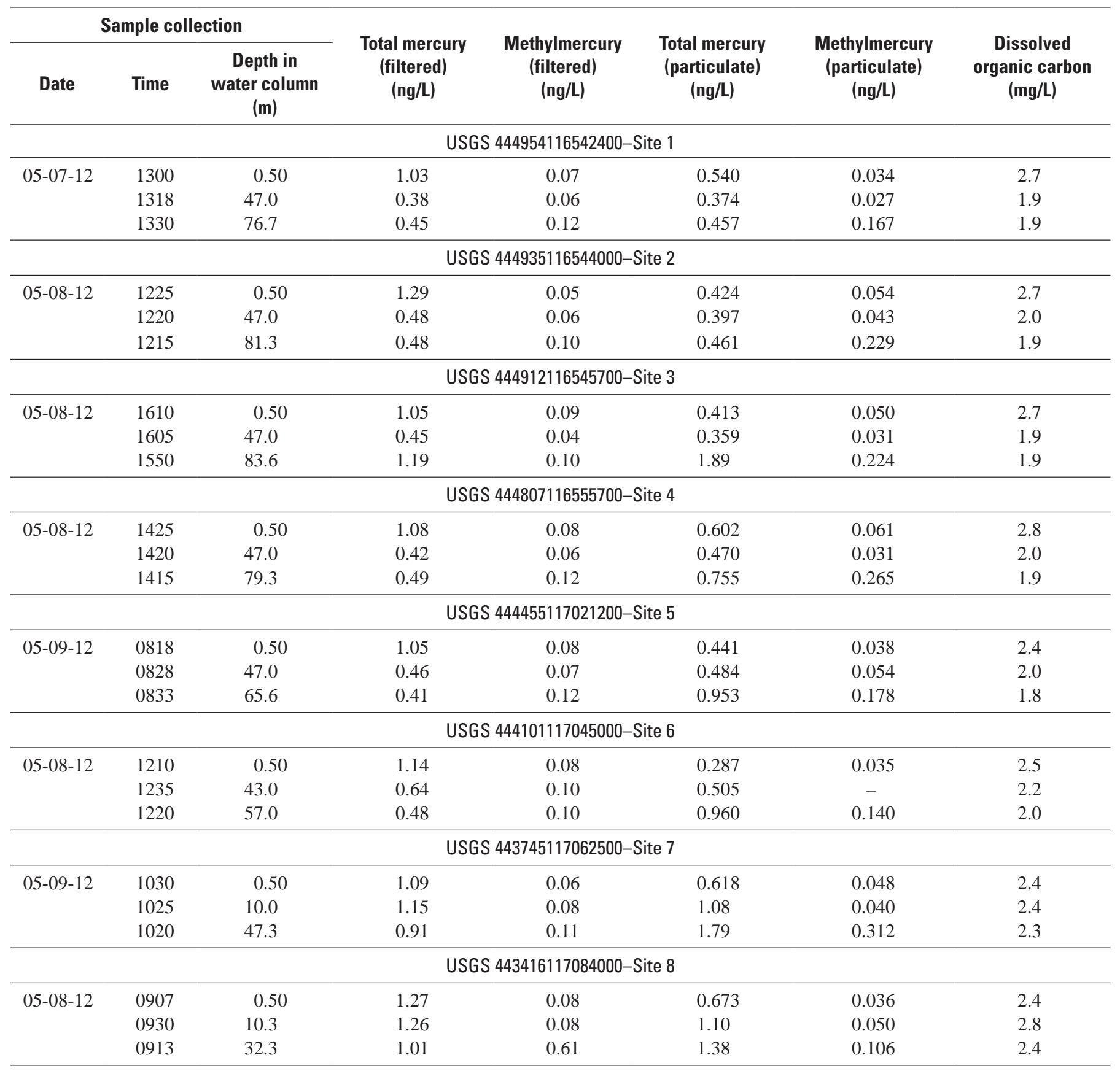


Table 4. Total mercury and methylmercury concentrations and selected physical characteristics of bed-sediment samples collected from Brownlee Reservoir near Oxbow, Oregon, May 7-9, 2012.

[Samples analyzed at U.S. Geological Survey Mercury Research Laboratory according to laboratory methodologies listed in table 2. Abbreviations: m, meter; $\mu \mathrm{g} / \mathrm{kg}$, microgram per kilogram; USGS, U.S. Geological Survey]

\begin{tabular}{|c|c|c|c|c|c|c|}
\hline $\begin{array}{l}\text { Sample } \\
\text { date }\end{array}$ & Time & $\begin{array}{c}\text { Sample } \\
\text { interval } \\
(\mathrm{m})\end{array}$ & $\begin{array}{c}\text { Total } \\
\text { mercury } \\
\text { ( } \mu \mathrm{g} / \mathrm{kg})\end{array}$ & $\begin{array}{l}\text { Methylmercury } \\
(\mu \mathrm{g} / \mathrm{kg})\end{array}$ & $\begin{array}{l}\text { Dry weight } \\
\text { percent } \\
\text { solids } \\
\text { (percent) }\end{array}$ & $\begin{array}{l}\text { Loss on } \\
\text { ignition } \\
\text { (percent) }\end{array}$ \\
\hline \multicolumn{7}{|c|}{ USGS 444954116542400-Site 1} \\
\hline \multirow[t]{9}{*}{ 05-07-12 } & 1351 & $0-0.01$ & 98.2 & 15 & 8.58 & 17.28 \\
\hline & 1352 & $0.01-0.02$ & 64.5 & 6.1 & 9.32 & 15.66 \\
\hline & 1353 & $0.02-0.05$ & 86.1 & 2.8 & 11.88 & 9.29 \\
\hline & 1354 & $0.05-0.1$ & 96.3 & 3.1 & 11.11 & 12.98 \\
\hline & 1355 & $0.1-0.15$ & 99.6 & 1.2 & 10.22 & 13.47 \\
\hline & 1356 & $0.15-0.25$ & 100 & 0.94 & 14.01 & 13.45 \\
\hline & 1357 & $0.25-0.3$ & 91.7 & 0.88 & 16.28 & 9.65 \\
\hline & 1358 & $0.3-0.35$ & 110 & 0.6 & 21.18 & 6.95 \\
\hline & 1350 & $0.35-0.4$ & 84.6 & 0.73 & 19.97 & 8.59 \\
\hline \multicolumn{7}{|c|}{ USGS 444935116544000 - Site 2} \\
\hline \multirow[t]{9}{*}{ 05-09-12 } & 1240 & 0-0.01 & 99.2 & 18 & 8.7 & 15.36 \\
\hline & 1241 & $0.01-0.02$ & 61 & 5.2 & 9.11 & 15.14 \\
\hline & 1242 & $0.02-0.05$ & 97.7 & 5.3 & 8.21 & 11.27 \\
\hline & 1243 & $0.05-0.1$ & 90.9 & 2.4 & 12.2 & 11.95 \\
\hline & 1244 & $0.1-0.15$ & 100 & 1.3 & 9.74 & 14.03 \\
\hline & 1245 & $0.15-0.25$ & 105 & 1.1 & 14.44 & 11.77 \\
\hline & 1246 & $0.25-0.3$ & 98.2 & 1.1 & 12.95 & 11.37 \\
\hline & 1247 & $0.3-0.35$ & 97 & 0.58 & 21.62 & 8.47 \\
\hline & 1248 & $0.35-0.4$ & 80.3 & 0.64 & 19.11 & 8.48 \\
\hline \multicolumn{7}{|c|}{ USGS 444912116545700—Site 3} \\
\hline \multirow[t]{8}{*}{ 05-08-12 } & 1630 & 0-0.01 & 103 & 18 & 8.13 & 13.84 \\
\hline & 1631 & $0.01-0.03$ & 77.9 & 7.7 & 8.39 & 15.57 \\
\hline & 1632 & $0.03-0.07$ & 83.3 & 4.2 & 8.82 & 9.51 \\
\hline & 1633 & $0.07-0.12$ & 93.6 & 3.2 & 13.34 & 11.23 \\
\hline & 1634 & $0.12-0.17$ & 98.4 & 1.5 & 10.7 & 16 \\
\hline & 1635 & $0.17-0.22$ & 112 & 1 & 15.86 & 8.98 \\
\hline & 1636 & $0.22-0.32$ & 104 & 2 & 11.81 & 16.03 \\
\hline & 1637 & $0.32-0.42$ & 101 & 0.74 & 17.62 & 9.55 \\
\hline \multicolumn{7}{|c|}{ USGS 444807116555700 -Site 4} \\
\hline \multirow[t]{9}{*}{ 05-08-12 } & 1440 & 0-0.01 & 81.8 & 13 & 6.75 & 14.16 \\
\hline & 1441 & $0.01-0.03$ & 74.2 & 5.3 & 8.53 & 14.91 \\
\hline & 1442 & $0.03-0.05$ & 77.6 & 8.5 & 5.52 & 13.74 \\
\hline & 1443 & $0.05-0.07$ & 88.4 & 2.4 & 9.84 & 9.97 \\
\hline & 1444 & $0.07-0.09$ & 84.9 & 4.6 & 7.59 & 13.16 \\
\hline & 1445 & $0.09-0.11$ & 80.2 & 7.2 & 7.42 & 11.62 \\
\hline & 1446 & $0.11-0.21$ & 74.2 & 2.1 & 15.38 & 10.73 \\
\hline & 1447 & $0.21-0.31$ & 84.8 & 1.7 & 15.00 & 12.25 \\
\hline & 1448 & $0.31-0.41$ & 96.3 & 0.86 & 16.83 & 11.08 \\
\hline
\end{tabular}


Table 4. Total mercury and methylmercury concentrations and selected physical characteristics of bed-sediment samples collected from Brownlee Reservoir near Oxbow, Oregon, May 7-9, 2012.-Continued

[Samples analyzed at U.S. Geological Survey Mercury Research Laboratory according to laboratory methodologies listed in table 2. Abbreviations: m, meter; $\mu \mathrm{g} / \mathrm{kg}$, microgram per kilogram; USGS, U.S. Geological Survey]

\begin{tabular}{|c|c|c|c|c|c|c|}
\hline $\begin{array}{l}\text { Sample } \\
\text { date }\end{array}$ & Time & $\begin{array}{c}\text { Sample } \\
\text { interval } \\
\text { (m) }\end{array}$ & $\begin{array}{c}\text { Total } \\
\text { mercury } \\
(\mu \mathrm{g} / \mathrm{kg})\end{array}$ & $\begin{array}{l}\text { Methylmercury } \\
(\mu \mathrm{g} / \mathrm{kg})\end{array}$ & $\begin{array}{l}\text { Dry weight } \\
\text { percent } \\
\text { solids } \\
\text { (percent) }\end{array}$ & $\begin{array}{l}\text { Loss on } \\
\text { ignition } \\
\text { (percent) }\end{array}$ \\
\hline \multicolumn{7}{|c|}{ USGS 444455117021200—Site 5} \\
\hline \multirow[t]{8}{*}{ 05-09-12 } & 0850 & 0-0.02 & 75.1 & 7.3 & 6.44 & 12.56 \\
\hline & 0851 & $0.02-0.04$ & 74.1 & 5.7 & 8.06 & 11.22 \\
\hline & 0852 & $0.04-0.06$ & 70.8 & 3 & 11.16 & 11.43 \\
\hline & 0853 & $0.06-0.08$ & 71.1 & 4.1 & 9.16 & 12.22 \\
\hline & 0854 & $0.08-0.1$ & 78.2 & 2 & 17.58 & 7.88 \\
\hline & 1440 & $0.1-0.2$ & 75.9 & 1.7 & 19.62 & 11.02 \\
\hline & 1441 & $0.2-0.3$ & 82.5 & 1.2 & 13.98 & 12.34 \\
\hline & 1442 & $0.3-0.4$ & 78.6 & 0.54 & 25.05 & 7.95 \\
\hline \multicolumn{7}{|c|}{ USGS 444101117045000_-Site 6} \\
\hline \multirow[t]{9}{*}{ 05-08-12 } & 1250 & 0-0.01 & 99.2 & 12 & 6.86 & 12.25 \\
\hline & 1251 & $0.01-0.03$ & 91.7 & 12 & 11.02 & 10.52 \\
\hline & 1252 & $0.03-0.05$ & 81.1 & 11 & 12.26 & 11.87 \\
\hline & 1253 & $0.05-0.07$ & 73.4 & 5.5 & 13.52 & 12.53 \\
\hline & 1254 & $0.07-0.09$ & 73.1 & 2.2 & 16.07 & 8.8 \\
\hline & 1255 & $0.09-0.11$ & 75.8 & 2 & 17.18 & 8.75 \\
\hline & 1256 & $0.11-0.21$ & 73.6 & 1.8 & 17.24 & 9.61 \\
\hline & 1257 & $0.21-0.31$ & 68.2 & 1.8 & 21.57 & 7.35 \\
\hline & 1258 & $0.31-0.41$ & 77.2 & 1.4 & 20.09 & 10.15 \\
\hline \multicolumn{7}{|c|}{ USGS 443745117062500 - Site 7} \\
\hline \multirow[t]{8}{*}{ 05-09-12 } & 1045 & $0-0.02$ & 84.9 & 12 & 15.29 & 10.71 \\
\hline & 1046 & $0.02-0.04$ & 71.4 & 6.3 & 16.5 & 10.43 \\
\hline & 1047 & $0.04-0.06$ & 62.2 & 1.6 & 20.18 & 8.14 \\
\hline & 1048 & $0.06-0.08$ & 65.4 & 2 & 20.42 & 8.84 \\
\hline & 1049 & $0.08-0.11$ & 67.4 & 1.6 & 19.85 & 8.59 \\
\hline & 1050 & $0.11-0.23$ & 64.1 & 1.4 & 19.89 & 9.54 \\
\hline & 1051 & $0.23-0.33$ & 65.4 & 1.4 & 24.86 & 14.4 \\
\hline & 1052 & $0.33-0.43$ & 67.8 & 0.72 & 19.93 & 10.5 \\
\hline \multicolumn{7}{|c|}{ USGS 443416117084000 -Site 8} \\
\hline \multirow[t]{10}{*}{$05-08-12$} & 0945 & $0-0.01$ & 75.9 & 10 & 12.84 & 10.48 \\
\hline & 0946 & $0.01-0.03$ & 72.7 & 8.1 & 20.68 & 8.82 \\
\hline & 0947 & $0.03-0.05$ & 74.7 & 4.2 & 22.19 & 8.21 \\
\hline & 0948 & $0.05-0.1$ & 57.8 & 1.2 & 23.66 & 8.72 \\
\hline & 0949 & $0.1-0.12$ & 60.6 & 1.8 & 27.03 & 7.16 \\
\hline & 0950 & $0.12-0.14$ & 51.4 & 1.1 & 28.53 & 7.87 \\
\hline & 0951 & $0.14-0.18$ & 56.8 & 0.78 & 26.25 & 6.68 \\
\hline & 0952 & $0.18-0.24$ & 54.3 & 0.52 & 22.51 & 8.95 \\
\hline & 0953 & $0.24-0.28$ & 55.8 & 0.36 & 23.62 & 9.41 \\
\hline & 0954 & $0.28-0.29$ & 54.7 & 0.46 & 31.53 & 7.06 \\
\hline
\end{tabular}


Table 5. Selected herbicide and carbamate insecticide concentrations in bed-sediment core samples collected at selected sites at Brownlee Reservoir near Oxbow, Oregon, May 7-9, 2012.

[Samples analyzed at University of Idaho-Analytical Sciences Laboratory according to laboratory methodologies listed in table 2. All values are in micrograms per kilogram (wet weight). NWIS site name: Top subsample designated “a” (0-30 cm), and a bottom subsample designated "b” (30-75 cm). CASRN: Chemical Abstracts Service (CAS) Registry Number ${ }^{\circledR}$, a registered trademark of the American Chemical Society. CAS recommends the verification of the CASRNs through CAS Client Services ${ }^{\mathrm{SM}}$. Abbreviations: NWIS, National Water Information System; GC/MC, gas chromatography/mass spectometry; cm, centimeter; ND, not detected; <, less than]

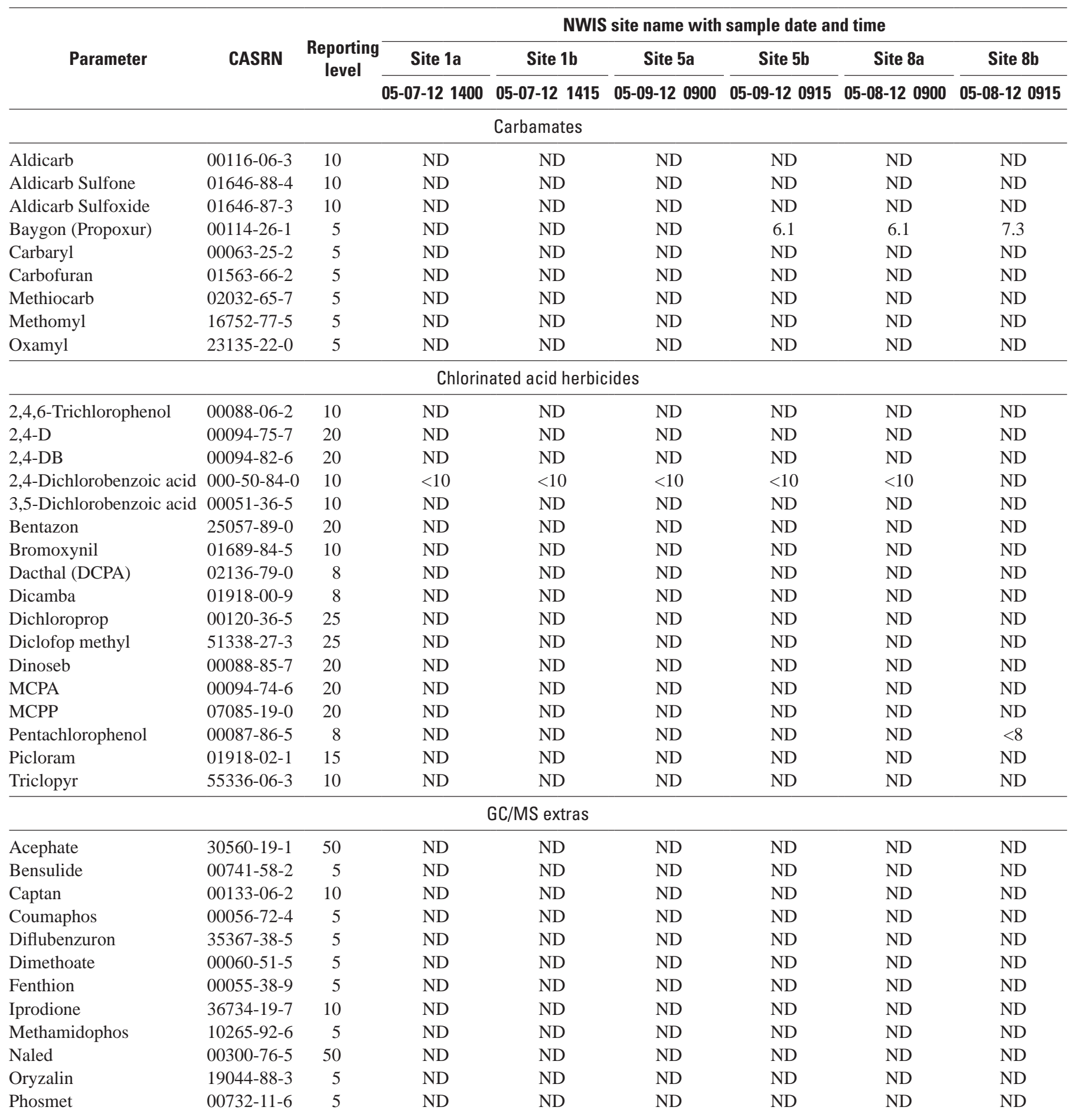


Table 5. Selected herbicide and carbamate insecticide concentrations in bed-sediment core samples collected at selected sites at Brownlee Reservoir near Oxbow, Oregon, May 7-9, 2012.-Continued

[Samples analyzed at University of Idaho-Analytical Sciences Laboratory according to laboratory methodologies listed in table 2. All values are in micrograms per kilogram (wet weight). NWIS site name: Top subsample designated "a” (0-30 cm), and a bottom subsample designated "b” (30-75 cm). CASRN: Chemical Abstracts Service (CAS) Registry Number ${ }^{\circledR}$, a registered trademark of the American Chemical Society. CAS recommends the verification of the CASRNs through CAS Client Services ${ }^{\text {SM }}$. Abbreviations: NWIS, National Water Information System; GC/MC, gas chromatography/mass spectometry; cm, centimeter; ND, not detected; $<$, less than]

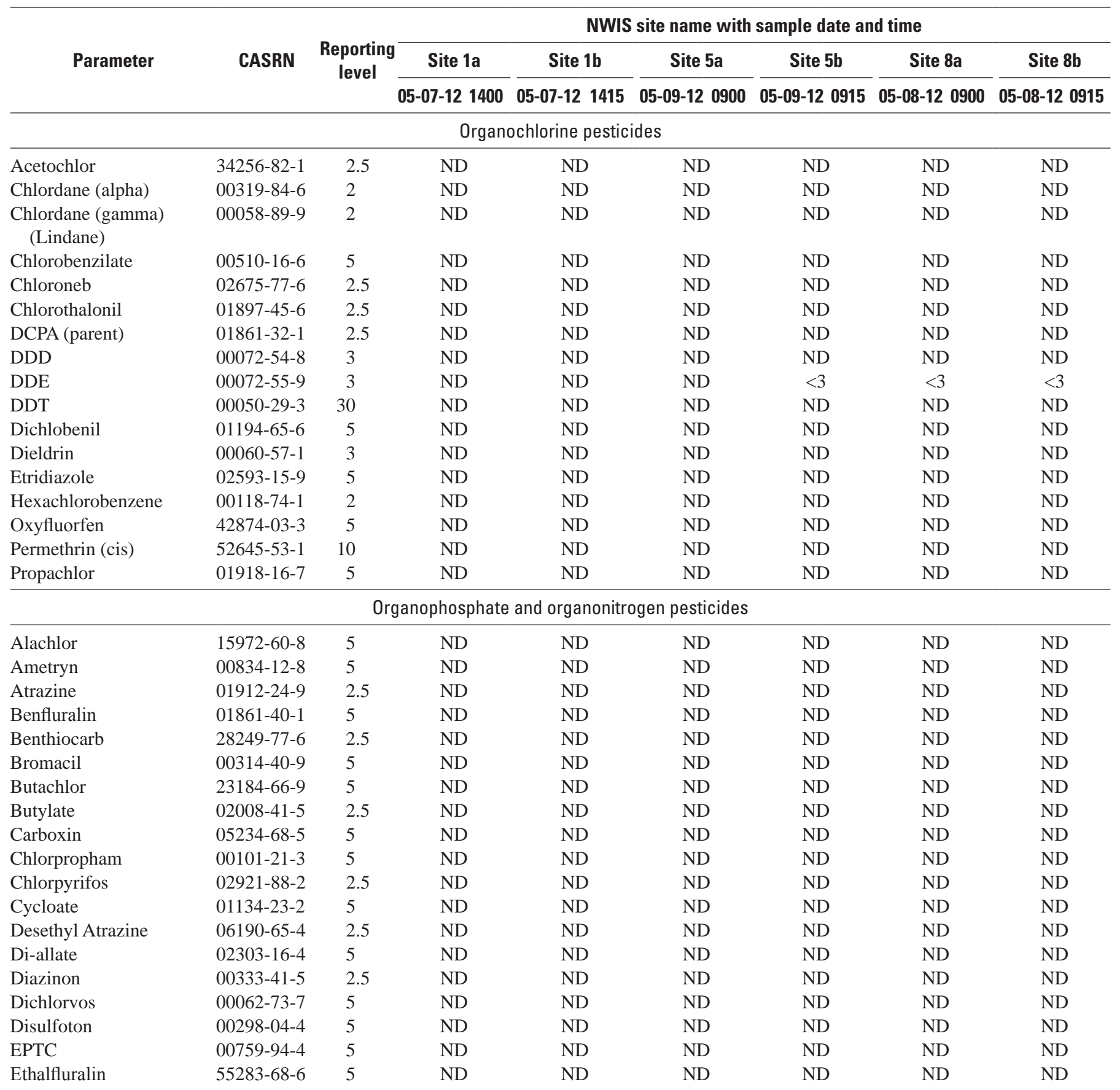


Table 5. Selected herbicide and carbamate insecticide concentrations in bed-sediment core samples collected at selected sites at Brownlee Reservoir near Oxbow, Oregon, May 7-9, 2012.-Continued

[Samples analyzed at University of Idaho-Analytical Sciences Laboratory according to laboratory methodologies listed in table 2. All values are in micrograms per kilogram (wet weight). NWIS site name: Top subsample designated “a” (0-30 cm), and a bottom subsample designated "b” (30-75 cm). CASRN: Chemical Abstracts Service (CAS) Registry Number ${ }^{\circledR}$, a registered trademark of the American Chemical Society. CAS recommends the verification of the CASRNs through CAS Client Services ${ }^{\mathrm{SM}}$. Abbreviations: NWIS, National Water Information System; GC/MC, gas chromatography/mass spectometry; cm, centimeter; ND, not detected; <, less than]

\begin{tabular}{|c|c|c|c|c|c|c|c|c|}
\hline \multirow{3}{*}{ Parameter } & \multirow{3}{*}{ CASRN } & \multirow{3}{*}{$\begin{array}{c}\text { Reporting } \\
\text { level }\end{array}$} & \multicolumn{6}{|c|}{ NWIS site name with sample date and time } \\
\hline & & & Site 1a & Site $\mathbf{1 b}$ & Site $5 \mathbf{a}$ & Site $5 b$ & Site 8a & Site $\mathbf{8 b}$ \\
\hline & & & 05-07-12 1400 & 05-07-12 1415 & 05-09-12 0900 & 05-09-12 0915 & 05-08-12 0900 & 05-08-12 0915 \\
\hline \multicolumn{9}{|c|}{ Organophosphate and organonitrogen pesticides-Continued } \\
\hline Ethoprop & 13194-48-4 & 2.5 & ND & ND & ND & ND & ND & ND \\
\hline Fenamiphos & 22224-92-6 & 5 & ND & ND & ND & ND & ND & ND \\
\hline Fenarimol & 60168-88-9 & 5 & ND & ND & ND & ND & ND & ND \\
\hline Hexazinone & 51235-04-2 & 5 & ND & ND & ND & ND & ND & ND \\
\hline Malathion & 00121-75-5 & 5 & ND & ND & ND & ND & ND & ND \\
\hline Metalaxyl & 57837-19-1 & 5 & ND & ND & ND & ND & ND & ND \\
\hline Methidathion & 00950-37-8 & 5 & ND & ND & ND & ND & ND & ND \\
\hline Methyl Paraoxon & 00950-35-6 & 10 & ND & ND & ND & ND & ND & ND \\
\hline Methyl Parathion & 00298-00-0 & 5 & ND & ND & ND & ND & ND & ND \\
\hline Metolachlor & $51218-45-2$ & 5 & ND & ND & ND & ND & ND & ND \\
\hline Metribuzin & 21087-64-9 & 2.5 & ND & ND & ND & ND & ND & ND \\
\hline Napropamide & 15299-99-7 & 5 & ND & ND & ND & ND & ND & ND \\
\hline Norflurazon & 27314-13-2 & 5 & ND & ND & ND & ND & ND & ND \\
\hline Parathion & 00056-38-2 & 5 & ND & ND & ND & ND & ND & ND \\
\hline Pendimethalin & $40487-42-1$ & 2.5 & ND & ND & ND & ND & ND & ND \\
\hline Phorate & 00298-02-2 & 5 & ND & ND & ND & ND & ND & ND \\
\hline Prometon & 01610-18-0 & 5 & ND & ND & ND & $<5$ & $<5$ & $<5$ \\
\hline Pronamide & 23950-58-5 & 5 & ND & ND & ND & ND & ND & ND \\
\hline Propazine & 00139-40-2 & 2.5 & ND & ND & ND & ND & ND & ND \\
\hline Simazine & 00122-34-9 & 2.5 & ND & ND & ND & ND & ND & ND \\
\hline Terbacil & 05902-51-2 & 5 & ND & ND & ND & ND & ND & ND \\
\hline Terbufos & 13071-79-9 & 5 & ND & ND & ND & ND & ND & ND \\
\hline Triallate & 02303-17-5 & 5 & ND & ND & ND & ND & ND & ND \\
\hline Triadimefon & $43121-43-3$ & 5 & ND & ND & ND & ND & ND & ND \\
\hline \multicolumn{9}{|c|}{ Urea pesticides } \\
\hline $\begin{array}{l}\text { Deisopropyl atrazine } \\
\text { (DIA) }\end{array}$ & $01007-28-9$ & 2.5 & ND & ND & ND & ND & ND & ND \\
\hline Diuron & 00330-54-1 & 2.5 & ND & ND & ND & ND & ND & ND \\
\hline Linuron & $00330-55-2$ & 5 & ND & ND & ND & ND & ND & ND \\
\hline Tebuthiuron & $34014-18-1$ & 5 & ND & ND & ND & ND & ND & ND \\
\hline Tralkoxydim & 87820-88-0 & 5 & ND & ND & ND & ND & ND & ND \\
\hline
\end{tabular}




\section{Pacific Agriculture Laboratory}

Pesticide and herbicide concentrations from the bed-sediment core samples from sites 1,5 , and 8 were analyzed at the Pacific Agriculture Laboratory (PacAg) (table 12; at back of report). One halogenated pesticide, p,p'-DDE, was detected at a concentration of $0.03 \mu \mathrm{g} / \mathrm{kg}$ in the core samples collected at site $5 b$. Organophosphorus and organosulfur pesticides, organonitrogen pesticides, phenylurea herbicides, and carbamate insecticides were not detected in any of the bed-sediment core samples.

The concentrations in the initial bed-sediment core samples analyzed at PacAg for the glyphosate and AMPA were higher than expected. Based on the initial results, follow-up analysis of glyphosate and AMPA was requested. Concentrations from the subsequent analyses at PacAg from core samples $1 \mathrm{~b}$ and $8 \mathrm{a}$ were much lower than the original results. The herbicide glyphosate was detected in one sample and the concentration was close to the reporting level. AMPA, the breakdown product of glyphosate, was not detected in any of the bed-sediment core samples. Additionally, a split core was sent to the OGRL for analysis. The OGRL analyzed for glyphosate, AMPA, and glufosinate, and all results were less than the reporting limit of $20 \mu \mathrm{g} / \mathrm{kg}$. Results for glyphosate, AMPA, and glufosinate sent to PacAg and OGRL laboratories for analysis on bed-sediment core samples are listed in table 6 .

\section{U.S. Geological Survey National Water Quality Laboratory}

The NWQL analyzed bed-sediment core samples from sites 1,5 , and 8 for wastewater compounds (table 7). Due to method performance variability, an analyte could have multiple reporting levels in some cases. Concentrations of most wastewater compounds in bed sediment were less than the method reporting levels. Some compound detections are reported at an estimated ("E") level; estimated values may be reported for constituents that were identified with a high level of confidence, but due to matrix interference or other analytical issues, their quantification was more uncertain. Estimated concentration values were considered detections for the bed-sediment samples in this study. The analytes 2,6-Dimethylnaphthalene, 3-Methyl-1(H)-indole (Skatole) (except 1b), 3-beta-Coprostanol, beta-Sitosterol, betaStigmastanol, Cholesterol, Indole, Isophorone (except 1a and $5 a)$, and p-Cresol were detected in all samples. Carbazole was detected in samples 5b, 8a, and 8b; 4-Nonylphenol (sum of all isomers) was detected in samples $1 \mathrm{~b}, 5 \mathrm{a}$, and $5 \mathrm{~b}$.

\section{U.S. Geological Survey Pesticide Fate Research Group}

The USGS-Pesticide Fate Research Group analyzed bed-sediment core samples for an array of pesticides, herbicides, and fungicides. Only samples from the top $(0-30 \mathrm{~cm})$ of the bed-sediment cores at sites $1 \mathrm{a}, 5 \mathrm{a}$, and $8 \mathrm{~b}$ (table 7) were submitted for analysis. Of the 90 analytes, 2 were detected in the bed-sediment core samples (table 8). One analyte, p,p'-DDE, was detected in samples from sites 1 and 8 at concentrations of 3.2 and $2.1 \mu \mathrm{g} / \mathrm{kg}$ (based on dry weight), respectively. Pendimethalin was detected at a concentration of $24.7 \mu \mathrm{g} / \mathrm{kg}$ in a single core sample collected at site 8 .

\section{Physical Characteristics and Trace Metals}

The Pace Analytical Laboratory analyzed selected bed-sediment core samples for physical characteristics (table 9). Total organic carbon in bed sediment ranged from 12,400 to $16,800 \mathrm{mg} / \mathrm{kg}$. Grain-size results for samples collected from sites 5 and 8 ranged from 66.0 to 75.8 percent clay and 24.2 to 34.0 percent silt. The $\mathrm{pH}$ of the sediment ranged from 7.0 to 7.9 , and reduction-oxidation (redox) potential in core samples from sites 5 and 8 ranged from 89.3 to 1,200 millivolts, decreasing both with depth and in a downstream direction. Because of a miscommunication with the analyzing laboratory, no data are available for total solids (all sites), grain-size analysis (sites $1 \mathrm{a}$ and $1 \mathrm{~b}$ ), $\mathrm{pH}$ (site $1 \mathrm{~b}$ ), and redox (sites 1a and 1b).

Trace metals in bed sediment samples were analyzed by the NWQL (table 10) and were greater than the reporting level in all the samples submitted for analysis. According to sediment quality guidelines published by MacDonald and others (2000), results for arsenic, copper, and nickel were between the consensus-based threshold effect concentration (TEC) and probable effect concentration (PEC) for freshwater ecosystems. The TEC indicates a concentration where adverse effects rarely occur, whereas the PEC indicates a concentration where adverse effects occur more often than not. Because the samples were neither less than the TEC nor greater than the PEC, the samples cannot be determined to be nontoxic or toxic based on these sediment quality guidelines. 


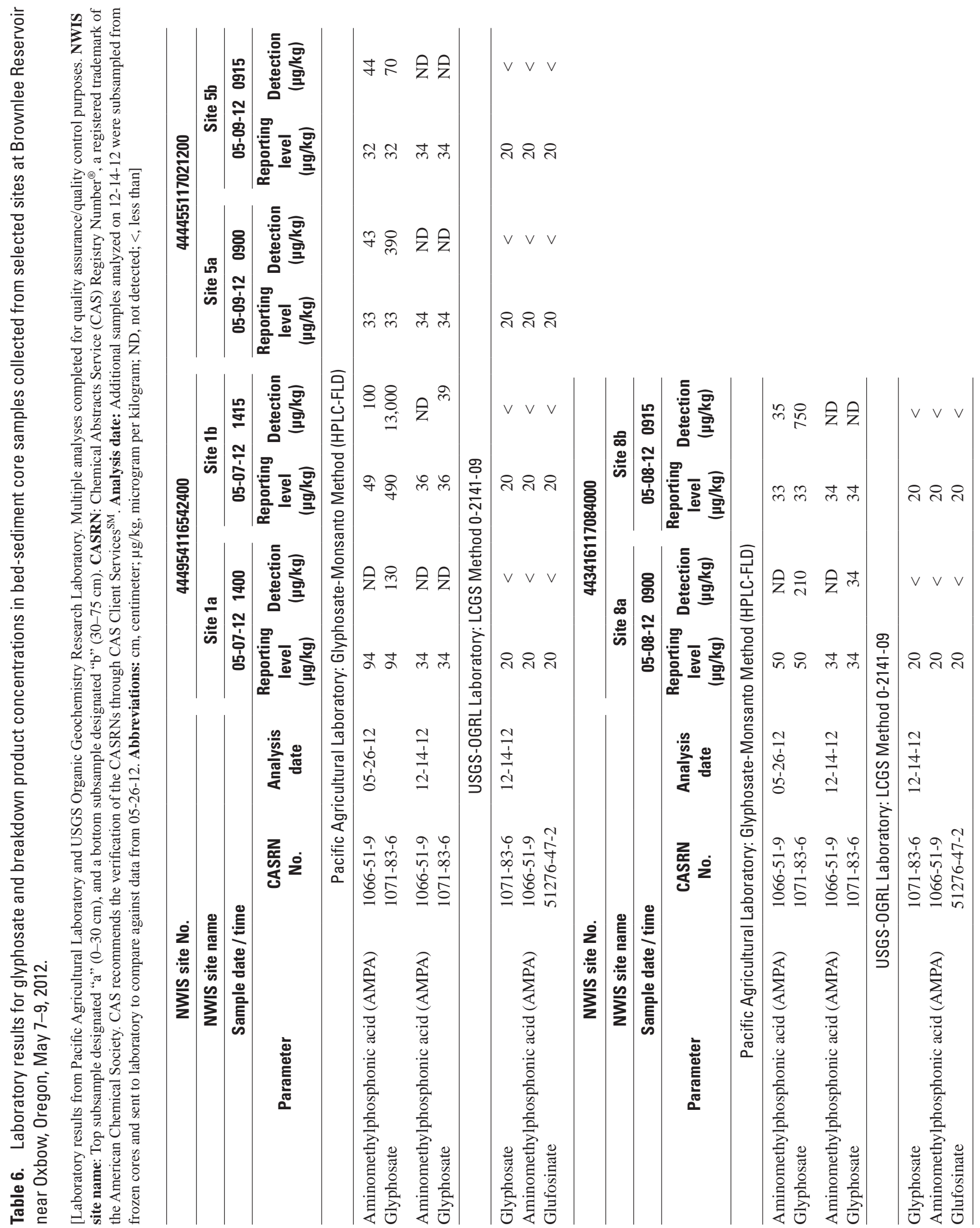




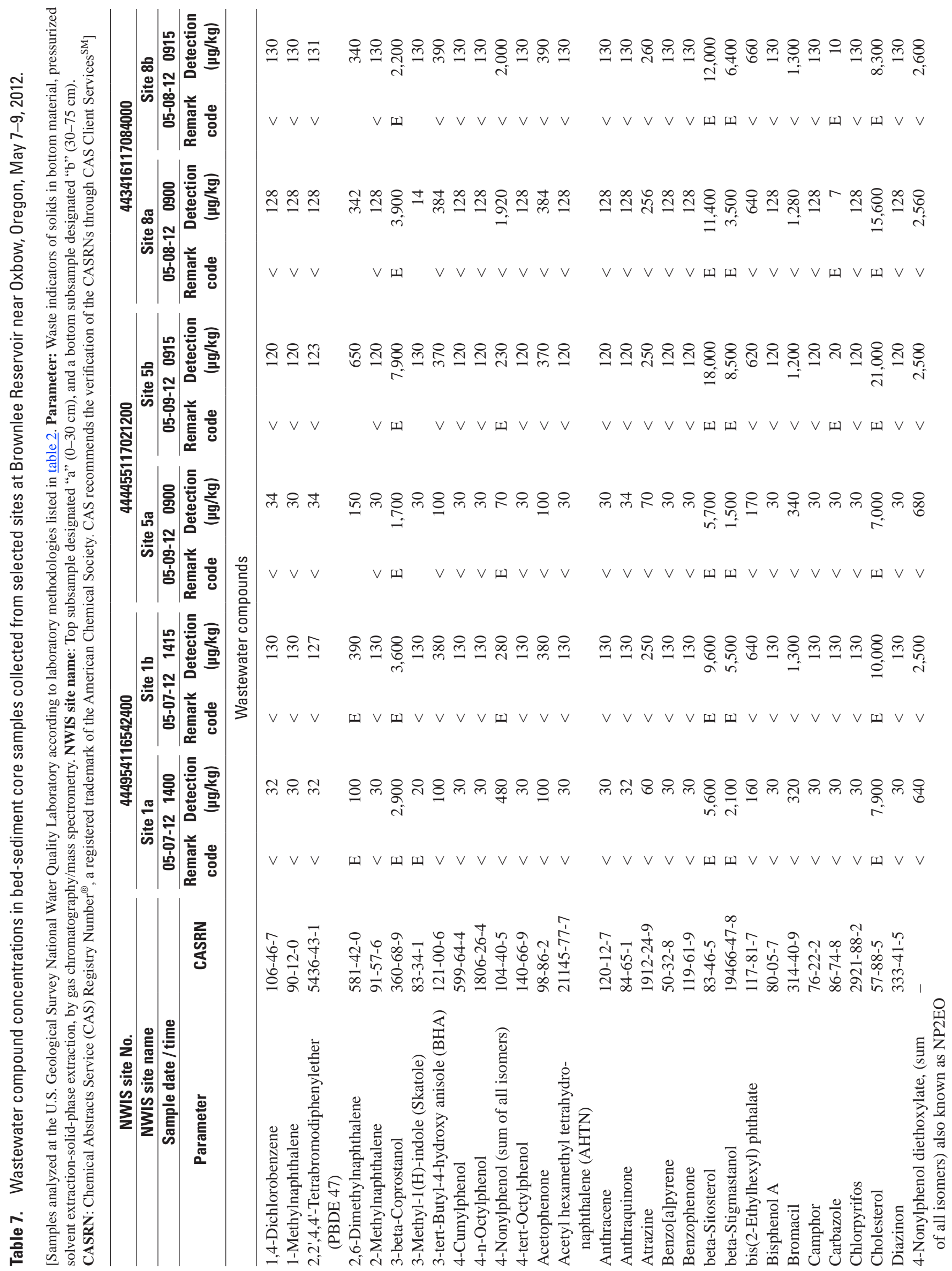




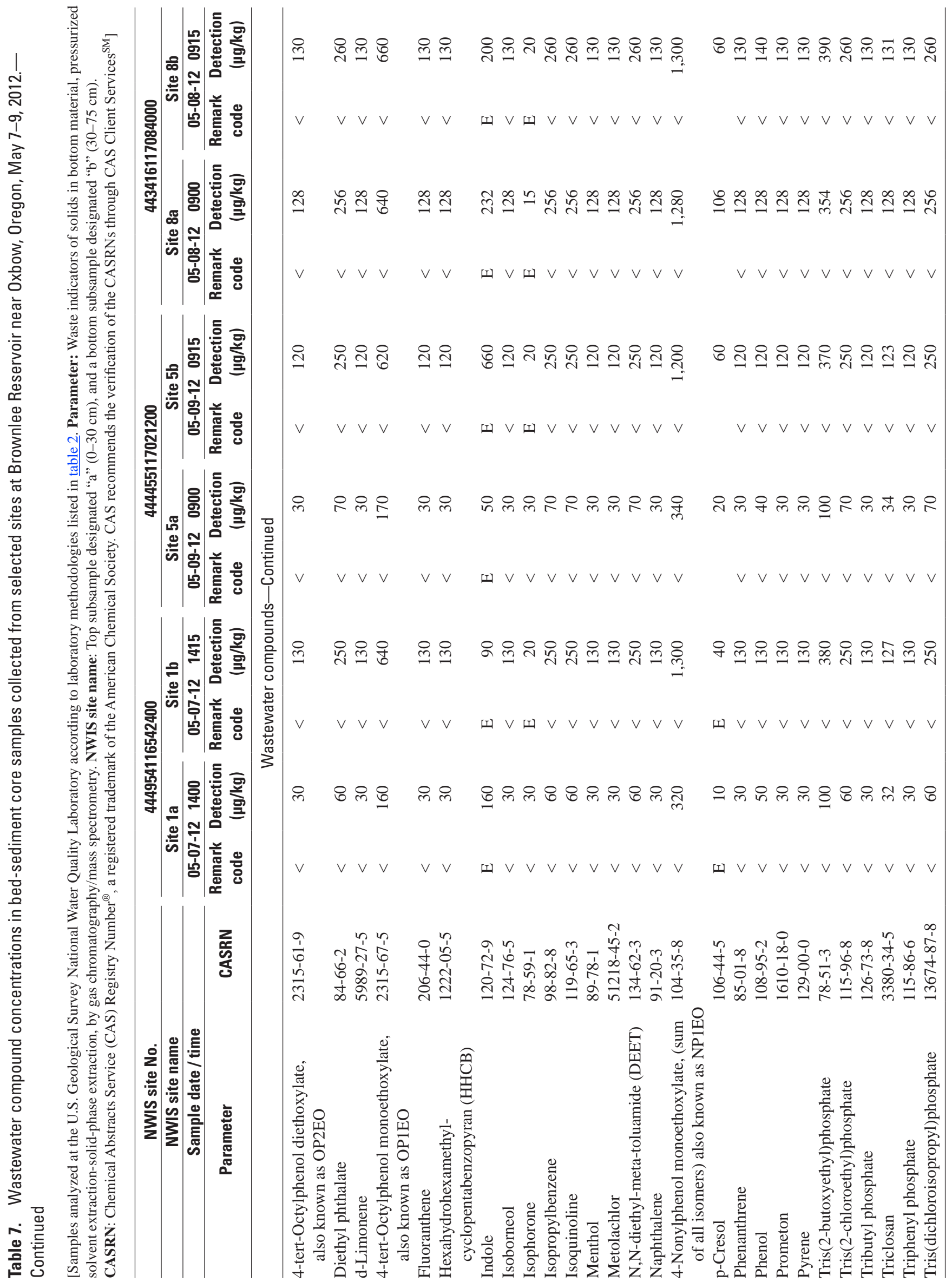


Table 8. Pesticide concentrations in bed-sediment core samples collected from selected sites at Brownlee Reservoir near Oxbow, Oregon, May 7-9, 2012.

[Samples analyzed by the U.S. Geological Survey Pesticide Fate Research Group according to laboratory methodologies listed in table 2. NWIS site name: Top subsample designated “a” (0-30 cm). CASRN: Chemical Abstracts Service (CAS) Registry Number ${ }^{\circledR}$, a registered trademark of the American Chemical Society. CAS recommends the verification of the CASRNs through CAS Client Services ${ }^{\text {SM }}$. Detection limit: Sediment method detection limit. Abbreviations: NWIS, National Water Information System; $\mu \mathrm{g} / \mathrm{kg}$, microgram per kilogram; cm, centimeter; ND, not detected]

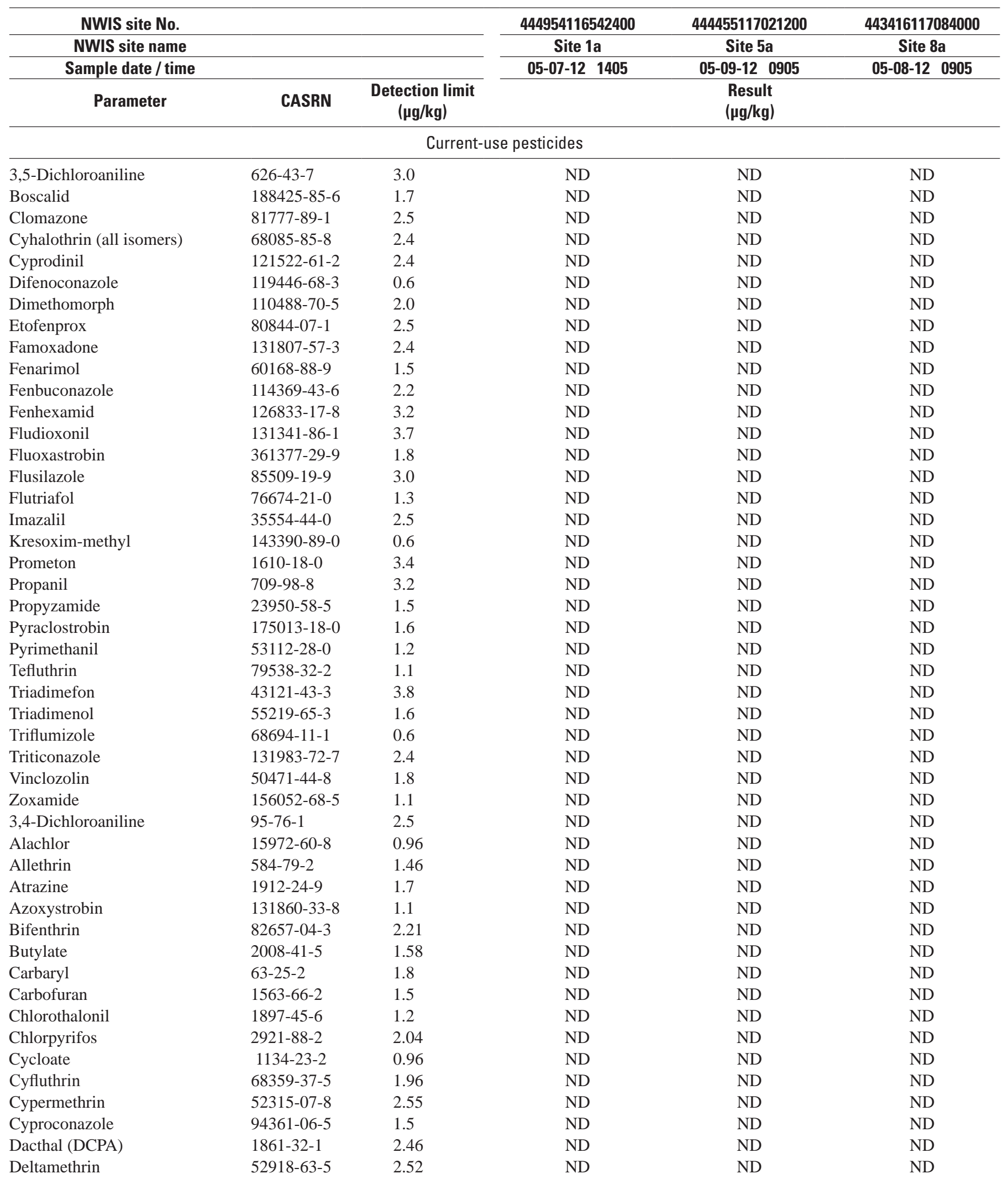


Table 8. Pesticide concentrations in bed-sediment core samples collected from selected sites at Brownlee Reservoir near Oxbow, Oregon, May 7-9, 2012.-Continued

[Samples analyzed by the U.S. Geological Survey Pesticide Fate Research Group according to laboratory methodologies listed in table 2. NWIS site name: Top subsample designated "a” (0-30 cm). CASRN: Chemical Abstracts Service (CAS) Registry Number ${ }^{\mathbb{R}}$, a registered trademark of the American Chemical Society. CAS recommends the verification of the CASRNs through CAS Client Services ${ }^{\text {SM }}$. Detection limit: Sediment method detection limit. Abbreviations: NWIS, National Water Information System; $\mu \mathrm{g} / \mathrm{kg}$, microgram per kilogram; cm, centimeter; ND, not detected]

\begin{tabular}{|c|c|c|c|c|c|}
\hline NWIS site No. & & & 444954116542400 & 444455117021200 & 443416117084000 \\
\hline NWIS site name & & & Site 1a & Site 5a & Site 8a \\
\hline Sample date / time & & & 05-07-12 1405 & 05-09-12 0905 & 05-08-12 0905 \\
\hline Parameter & CASRN & $\begin{array}{l}\text { Detection limit } \\
(\mu \mathrm{g} / \mathrm{kg})\end{array}$ & & $\begin{array}{c}\text { Result } \\
(\mu \mathrm{g} / \mathrm{kg})\end{array}$ & \\
\hline \multicolumn{6}{|c|}{ Current-use pesticides-Continued } \\
\hline Desulfinylfipronil & $205650-65-3$ & 2.76 & ND & ND & ND \\
\hline EPTC & 759-94-4 & 0.88 & ND & ND & ND \\
\hline Esfenvalerate & $66230-04-4$ & 2.13 & ND & ND & ND \\
\hline Ethalfluralin & $55283-68-6$ & 1.34 & ND & ND & ND \\
\hline Fenpropathrin & 39515-41-8 & 2.12 & ND & ND & ND \\
\hline Fipronil & $120068-37-3$ & 1.86 & ND & ND & ND \\
\hline Fipronil sulfide & 120067-83-6 & 2.22 & ND & ND & ND \\
\hline Malathion & $121-75-5$ & 1.09 & ND & ND & ND \\
\hline Metconazole & 125116-23-6 & 0.7 & ND & ND & ND \\
\hline Methidathion & $950-37-8$ & 2.9 & ND & ND & ND \\
\hline Methoprene & 40596-69-8 & 2.36 & ND & ND & ND \\
\hline Methyl parathion & $298-00-0$ & 1.21 & ND & ND & ND \\
\hline Metolachlor & $51218-45-2$ & 1.31 & ND & ND & ND \\
\hline Molinate & 2212-67-1 & 1.09 & ND & ND & ND \\
\hline Myclobutanil & 88671-89-0 & 2.9 & ND & ND & ND \\
\hline Napropamide & 15299-99-7 & 1.28 & ND & ND & ND \\
\hline Oxyfluorfen & $42874-03-3$ & 3.64 & ND & ND & ND \\
\hline Pebulate & 1114-71-2 & 1.38 & ND & ND & ND \\
\hline Simazine & $122-34-9$ & 1.5 & ND & ND & ND \\
\hline tau-Fluvalinate & 102851-06-9 & 2.6 & ND & ND & ND \\
\hline Tebuconazole & 107534-96-3 & 1.6 & ND & ND & ND \\
\hline Tetraconazole & 112281-77-3 & 1.3 & ND & ND & ND \\
\hline Tetramethrin & $7696-12-0$ & 1.36 & ND & ND & ND \\
\hline Thiobencarb & 28249-77-6 & 0.59 & ND & ND & ND \\
\hline Trifloxystrobin & 141517-21-7 & 1.4 & ND & ND & ND \\
\hline Trifluralin & $1582-09-8$ & 1.71 & ND & ND & ND \\
\hline \multicolumn{6}{|c|}{ Organochlorine pesticides } \\
\hline p,p'-DDD & $72-54-8$ & 1.26 & ND & ND & ND \\
\hline p,p'-DDE & $72-55-9$ & 1.4 & 3.2 & ND & 2.1 \\
\hline p,p'-DDT & $50-29-3$ & 1.4 & ND & ND & ND \\
\hline Pentachloroanisole (PCA) & $1825-21-4$ & 1.4 & ND & ND & ND \\
\hline Pentachloronitrobenzene (PCNB) & $82-68-8$ & 1.15 & ND & ND & ND \\
\hline
\end{tabular}



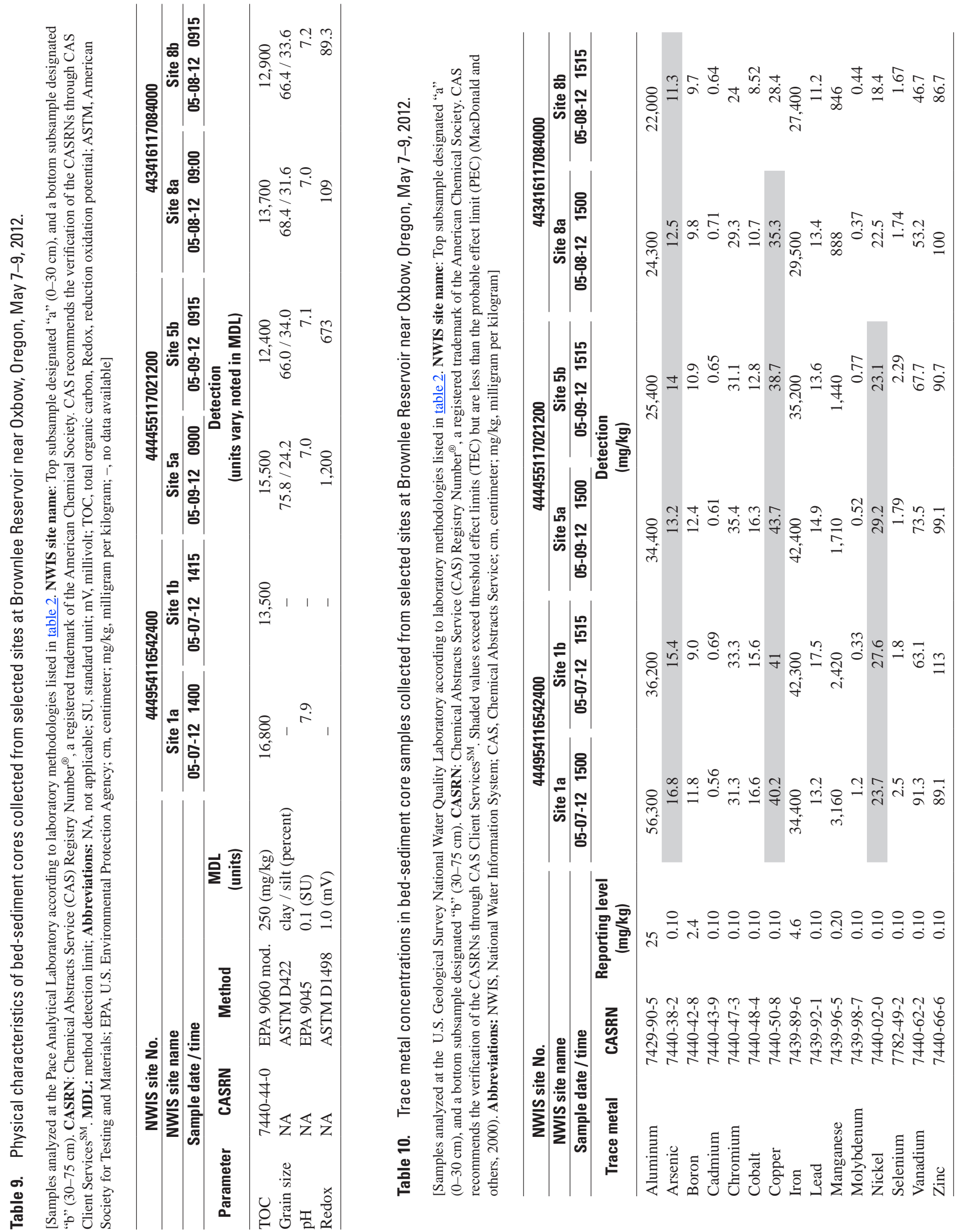


\section{Summary}

Total mercury and methylmercury were collected from water column and bed-sediment core samples at eight sites at Brownlee Reservoir near Oxbow, Oregon. Total methylmercury concentrations in the water column increased with depth. Total methylmercury in the bed sediment was largest near the sediment-water interface and decreased substantially with depth.

The bed-sediment core samples from sites 1, 5, and 8 were analyzed for 417 pesticides and other organic compounds. Only 17 of the 417 analytes were detected at or greater than the reporting level, and 11 of the detected analytes were wastewater compounds. Other organics detected in the bed sediment cores included the herbicides 2,4-Dichlorobenzoic acid and pentachlorphenol along with the pesticides 4,4'-DDE, pendimethalin, prometon, and propoxur; 4,4'-DDE was detected in all sediment samples that were analyzed. Initially, glyphosate (and AMPA) analysis indicated an anomalously high concentration of glyphosate, but further analysis at two separate laboratories verified that the initial samples were not accurate.

The physical characteristic analyses included total organic carbon, grain size, $\mathrm{pH}$, and redox. Total organic carbon was consistent throughout the reservoir ranging from 12,400 to 16,800 milligrams per kilogram. The grain size ranged from about 66 to 75.8 percent clay, and about 24 to 34 percent silt. The highest $\mathrm{pH}$ was 7.9 and occurred in the northern part of the reservoir at site 1 ; all other $\mathrm{pH}$ samples ranged from 7.0 to 7.2. Redox was not analyzed at site 1 ; however, redox decreased with depth at sites 5 and 8 and decreased in a downstream direction.

Trace metals were detected at greater than the reporting level in all bed-sediment core samples submitted for analysis. Three trace metals exceeded the sediment quality guidelines. Arsenic (all sites), copper (sites 1a and 1b, 5a and 5b, and 8a), and nickel (sites $1 \mathrm{a}$ and $1 \mathrm{~b}$ and $5 \mathrm{a}$ and $5 \mathrm{~b}$ ) each exceeded the threshold effect concentration (TEC), but were less than the probable effect concentration (PEC) for freshwater ecosystem. Because the concentrations were between the TEC and PEC, a determination of toxicity could not be determined.

\section{Acknowledgments}

The authors acknowledge the U.S. Fish and Wildlife Service, National Oceanic and Atmospheric Administration National Marine Fisheries Service, Idaho Department of Environmental Quality, Oregon Department of Environmental Quality, and Hyqual for their support and guidance during the planning stage of this study. The authors would also like to thank Marshall Williams, Greg Clark, Dan Hess, and Charles Thompson of the USGS for their assistance with data-collection efforts.

\section{References Cited}

ALS Environmental, 2013, EPA methods: ALS Environmental Web site, accessed September 4, 2013, at http://www.caslab. com/EPA-Methods/.

American Public Health Association, 1999, Standard methods for the examination of water and wastewater, 2540: Total Solids, 6 p.

American Public Health Association, 2006, Standard methods for the examination of water and wastewater: American Public Health Association Web site, accessed September 4, 2013, at http://www.standardmethods.org/.

American Society for Testing and Materials, 1990, ASTM standard practice D 1498-76: Philadelphia, Pa., American Society for Testing and Materials, p. 208-212.

American Society for Testing and Materials, 1998, ASTM Standard Practice D422-63: Philadelphia, Pa., American Society for Testing and Materials, 8 p.

American Society for Testing and Materials, 2013, General methods and instrumentation: American Society for Testing and Materials Web site, accessed November 7, 2013, at http://www.astm.org/DIGITAL LIBRARY/TOPICS/ PAGES/section14 stds.htm.

Brandt, D., 2007, Evaluation for total mercury contamination in Brownlee Reservoir tributary streams, Snake RiverHells Canyon TMDL, Idaho and Oregon: Kellogg, Idaho, TerraGraphics Environmental Engineering, 17 p.

Burkhardt, M.R., Zaugg, S.D., Smith, S.G., and ReVello, R.C., 2006, Determination of wastewater compounds in sediment and soil by pressurized solvent extraction, solid-phase extraction, and capillary-column gas chromatography/ mass spectrometry: U.S. Geological Survey Techniques and Methods, book 5, chap. B2, 40 p.

CH2M Hill, 2000, Brownlee Reservoir, Snake River and tributary bed-sediment contaminants: Boise, Idaho, Draft Technical Memorandum prepared for Idaho Power Company, 37 p.

Clark, G.M., and Maret, T.R., 1998, Organochlorine compounds and trace elements in fish tissue and bedsediments in the lower Snake River Basin, Idaho and Oregon: U.S. Geological Survey Water-Resources Investigations Report 98-4103, 35 p., http://pubs.er.usgs. gov/publication/wri984103.

DeWild, J.F., Olson, M.L., and Olund, S.D., 2002, Determination of methyl mercury by aqueous phase ethylation, followed by gas chromatographic separation with cold vapor atomic fluorescence Detection:

U.S. Geological Survey Open File Report 01-445, 14 p., http://pubs.usgs.gov/of/2001/ofr-01-445/. 
DeWild, J.F., Olund, S.D., Olson, M.L., and Tate, M.T., 2004, Methods for the preparation and analysis of solids and suspended solids of methylmercury: U.S. Geological Survey Techniques and Methods book 5, chap. A7, 13 p., http:// pubs.usgs.gov/tm/2005/tm5A7/.

Fishman, M.J., and Freidman, L.C., eds., 1989, Methods for determination of inorganic substances in water and fluvial sediments: U.S. Geological Survey Techniques of WaterResources Investigations, book 5, chap. A1, p. 48-451, http://pubs.usgs.gov/twri/twri5-a1/.

Garbarino, J.R., Kanagy, L.K., and Cree, M.E., 2006, Determination of elements in natural-water, biota, sediment, and soil samples using collision/reaction cell inductively coupled plasma-mass spectrometry: U.S. Geological Survey Techniques and Methods, book 5, chap. B1, 88 p., http:// pubs.usgs.gov/tm/2006/tm5b1/.

Harrison, J., Hinson, D.R., and Naymik, J., 2012, Brownlee Reservoir hypolimnion and discharge water-column toxics report: Boise, Idaho, Hyqual, P.A., Prepared for Idaho Power Company, 28 p., plus appendices.

Idaho Department of Environmental Quality and Oregon Department of Environmental Quality, 2004, Snake RiverHells Canyon total maximum daily load (TMDL): Idaho Department of Environmental Quality, Boise Regional Office, Idaho, and Oregon Department of Environmental Quality, Pendleton Office, Oregon, 710 p., plus appendices.

Idaho Power Company, 1991, Fall Chinook interim recovery plan and study: Boise, Idaho Power Company, 28 p.

Idaho Power Company, 2003, Hells Canyon Complex FERC No. 1971 License Application: Boise, Idaho Power Company.

Lewis, M.E., and Brigham, M.E., 2004, Low-level mercury (ver. 1.0): U.S. Geological Survey Techniques of WaterResources Investigations, book 9, chap. A5, sec. 5.6.4.B, 26 p., http://pubs.water.usgs.gov/twri9A5/.

MacDonald, D.D., Ingersoll, C.G., and Berger, T.A., 2000, Development and evaluation of consensus-based sediment quality guidelines for freshwater ecosystems: Archives of Environmental Contamination and Toxicology, v. 39, p. 20-31.

Meyer, M.T., Loftin, K.A., Lee, E.A., Hinshaw, G.H., Dietze, J.E., and Scribner, E.A., 2009, Determination of glyphosate, its degradation product aminomethylphosphonic acid, and glufosinate, in water by isotope dilution and online solidphase extraction and liquid chromatography/tandem mass spectrometry: U.S. Geological Survey Techniques and Methods, book 5, chap. A10, 32 p., http://pubs.usgs.gov/ preview/tm/tm5a10/.
Olund, S.D., DeWild, J.F., Olson, M.L., and Tate, M.T., 2004, Methods for the preparation and analysis of solids and suspended solids for total mercury: U.S. Geological Survey Techniques and Methods, book 5 chap. A8, 15 p., http:// pubs.usgs.gov/tm/2005/tm5A8/.

Radtke, D.B., 2005, Bottom-material samples (ver. 1.1): U.S. Geological Survey Techniques of Water-Resources Investigations, book 9, chap. A8, 56 p., http://pubs.water. usgs.gov/twri9A8/.

Shelton, L.R., and Capel, P.D., 1994, Guidelines for collecting and processing samples of stream bed sediment for analysis of trace elements and organic contaminants for the National Water- Quality Assessment Program: U.S. Geological Survey Open-File Report 94-458, 20 p., http://pubs.er.usgs. gov/publication/ofr94458.

Shimadzu, 2013, TOC-V Series product information page: Shimadzu, accessed March 5, 2013, at http://www.ssi. shimadzu.com/products/product.cfm?product=tocv.

Smalling, K.L., and Kuivila, K.M., 2008, Multi-residue method for the analysis of 85 current-use and legacy pesticides in bed and suspended sediments: Journal of Chromatography A, v. 1210, no. 1, p. 8-18, accessed August 19, 2013, at http://www.sciencedirect.com/science/ article/pii/S0021967308015513.

Stephan, C.E., Mount, D.I., Hanson, D.J., Gentile, J.H., Chapman, G.A., and Brungs, W.A., 1985, Guidelines for deriving numerical national water quality criteria for the protection of aquatic organisms and their uses: U.S. Environmental Protection Agency, PB85-227049, 98 p.

U.S. Environmental Protection Agency, 1986, Method 9060Total organic carbon, SW-846, chap. 5, 5 p., accessed August 19, 2013, at http://www.epa.gov/osw/hazard/ testmethods/sw846/pdfs/9060a.pdf.

U.S. Environmental Protection Agency, 1993, Method 632.1The determination of carbamate and urea pesticides in municipal and industrial wastewater: U.S. Environmental Agency, 821/R-93-010-A, 13 p., accessed August 19, 2013, at http://water.epa.gov/scitech/methods/cwa/bioindicators/ upload/2007 1106 methods method 632 1.pdf.

U.S. Environmental Protection Agency, 1994, Method 1613-Tetra- through octa-chlorinated dioxins and furans by isotope dilution HRGC/HRMS: U.S. Environmental Protection Agency, EPA Method Guidance, 86 p., accessed March 5, 2013, at http://water.epa.gov/scitech/methods/cwa/ organics/dioxins/upload/2007 0710 methods method dioxins 1613.pdf. 
U.S. Environmental Protection Agency, 1996a, Method 8151A — Chlorinated herbicides by GC using methylation or pentafluorobenzylation derivatization: U.S. Environmental Protection Agency SW-846, chap. 4.3.1, 31 p., accessed August 19, 2013, at http://www.epa.gov/osw/hazard/ testmethods/sw846/pdfs/8151a.pdf.

U.S. Environmental Protection Agency, 1996b, Method 8081A - Organochlorine pesticides by gas chromatography: U.S. Environmental Protection Agency SW-846, chap. 4.3.1, 57 p., accessed August 19, 2013, at http://www. epa.gov/osw/hazard/testmethods/sw846/pdfs/8081b.pdf.

U.S. Environmental Protection Agency, 1996c, Method 8270C—Semivolatile organic compounds by gas chromotography/mass spectrometry (GC/MS): U.S. Environmental Protection Agency SW-846, Chap. 4.3.2, accessed August 19, 2013, at http://www.caslab.com/EPAMethod-8270C/.

U.S. Environmental Protection Agency, 1996d, Method 8082-Polychlorinated biphenyls (PCBs) by gas chromatography: U.S. Environmental Protection Agency SW-846, chap. 4.3.1, accessed August 19, 2013, at http:// www.caslab.com/EPA-Method-8082/.

U.S. Environmental Protection Agency, 2000, Method 8141B-Organophosphorous compounds by gas chromatography: U.S. Environmental Protection Agency SW-846, Update IVB, accessed August 19, 2013, at http:// www.caslab.com/EPA-Method-8141B/.

U.S. Environmental Protection Agency, 2002, Method 1631, Revision E-Mercury in water by oxidation, purge and trap, and cold vapor atomic fluorescence spectrometry: U.S. Environmental Protection Agency EPA-821-R-02-019, accessed August 19, 2013, at http://www.caslab.com/EPAMethod-1631/.
U.S. Environmental Protection Agency, 2004, Method 9045D—Soil and waste pH: U.S. Environmental Protection Agency SW-846, chap. 6, accessed August 19, 2013, 2013, at http://www.caslab.com/EPA-Method-9045D/.

U.S. Environmental Protection Agency, 2007a, Method 7473-Mercury in solids and solutions by thermal decomposition, amalgamation, and atomic absorption spectrophotometry: U.S. Environmental Protection Agency, 17 p., accessed August 19, 2013, at http://www.caslab.com/ EPA-Method-7473/.

U.S. Environmental Protection Agency, 2007b, Method 8321b-Solvent-extractable nonvolatile compounds by high-performance liquid chromatography/thermospray/mass spectrometry (HPLC/TS/MS) or ultraviolet (UV) detection: U.S. Environmental Agency SW-846, 57 p., accessed August 19, 2013, at http://www.caslab.com/EPA-Method8321B/.

U.S. Geological Survey, 2013, USGS Mercury Research Laboratory: U.S. Geological Survey Web site, accessed September 4, 2013, at http://wi.water.usgs.gov/mercury-lab/ index.html.

van Metre, P.C., Wilson, J.T., Fuller, C.C., Callender, Edward, and Mahler, B.J., 2004, Collection, analysis, and age dating of sediment cores from 56 U.S. lakes and reservoirs sampled by the U.S. Geological Survey, 1992-2001: U.S. Geological Survey Scientific Investigations Report 20045184, 180 p., http://pubs.usgs.gov/sir/2004/5184/.

Wood, M.S., and Etheridge, A.B., 2011, Water-quality conditions near the confluence of the Snake and Boise Rivers, Canyon County, Idaho: U.S. Geological Survey Scientific Investigations Report 2011-5217, 70 p., http:// pubs.usgs.gov/sir/2011/5217/. 
Table 11. Organic compound concentrations in bed-sediment core samples collected from selected sites at Brownlee Reservoir near Oxbow, Oregon, May 7-9, 2012.

[Samples analyzed at Pace Analytical Services, Inc. according to laboratory methodologies listed in table 2. All values are in micrograms per kilogram (wet weight). NWIS site name: Top subsample designated “a” (0-30 cm), and a bottom subsample designated "b” (30-75 cm). CASRN: Chemical Abstracts Service (CAS) Registry Number ${ }^{\circledR}$, a registered trademark of the American Chemical Society. CAS recommends the verification of the CASRNs through CAS Client Services ${ }^{S M}$. MDL: method detection limit. RL: reporting level. Abbreviations: NWIS, National Water Information System; EPA, U.S. Environmental Protection Agency; SIM, selected ion monitoring; PCBs, polychlorinated biphenyls; TCDD,Tetrachlorodibenzo-p-dioxin; ND, not detected; cm centimeter; $\mu \mathrm{g} / \mathrm{kg}$, microgram per kilogram; -, no data available]

\begin{tabular}{|c|c|c|c|c|c|c|c|}
\hline \multirow{3}{*}{$\begin{array}{c}\text { NWIS site No. } \\
\text { NWIS site name } \\
\text { Sample date and time }\end{array}$} & & \multicolumn{6}{|c|}{444954116542400} \\
\hline & & \multicolumn{3}{|c|}{ Site 1a } & \multicolumn{3}{|c|}{ Site 1b } \\
\hline & & \multicolumn{3}{|c|}{ 05-07-12 1400} & \multicolumn{3}{|c|}{ 05-07-12 1415} \\
\hline \multicolumn{8}{|c|}{ Semivolatile organics (SVOC)_EPA 8270} \\
\hline 1,2-Diphenylhydrazine & $122-66-7$ & ND & 358 & 15,600 & ND & 177 & 7,760 \\
\hline 1,3-Dichlorobenzene & $541-73-1$ & ND & 695 & 3,040 & ND & 344 & 1,510 \\
\hline 1,4-Dichlorobenzene & $106-46-7$ & ND & 647 & 3,040 & ND & 321 & 1,510 \\
\hline 1-Methylnaphthalene & $90-12-0$ & ND & 439 & 3,040 & ND & 218 & 1,510 \\
\hline 2,4,5-Trichlorophenol & $95-95-4$ & ND & 521 & 15,600 & ND & 258 & 7,760 \\
\hline 2,4-Dinitrotoluene & $121-14-2$ & ND & 424 & 3,040 & ND & 210 & 1,510 \\
\hline 2.6-Dinitrotoluene & $606-20-2$ & ND & 424 & 3,040 & ND & 210 & 1,510 \\
\hline 2-Chloronaphthalene & $91-58-7$ & ND & 366 & 3,040 & ND & 182 & 1,510 \\
\hline 2-Chlorophenol & $95-57-8$ & ND & 667 & 3,040 & ND & 331 & 1,510 \\
\hline 2-Methylnaphthalene & $91-57-6$ & ND & 449 & 3,040 & ND & 223 & 1,510 \\
\hline 2-Methylphenol(o-Cresol) & $95-48-7$ & ND & 465 & 3,040 & ND & 230 & 1,510 \\
\hline 2-Nitroaniline & $88-74-4$ & ND & 422 & 15,600 & ND & 209 & 7,760 \\
\hline 2-Nitrophenol & $88-75-5$ & ND & 504 & 3,040 & ND & 250 & 1,510 \\
\hline 3\&4-Methylphenol & 108-39-4 [3] and 106-44-5 [4] & ND & 408 & 6,080 & ND & 202 & 3,010 \\
\hline 3,3’-Dichlorobenzidine & $91-94-1$ & ND & 3,080 & 6,170 & ND & 1,530 & 3,060 \\
\hline 3-Nitroaniline & $99-09-2$ & ND & 597 & 15,600 & ND & 296 & 7,760 \\
\hline Acenaphthene & 183-32-9 & ND & 360 & 3,040 & ND & 178 & 1,510 \\
\hline Acenaphthylene & ${ }^{1} 208-96-8$ & ND & 352 & 3,040 & ND & 174 & 1,510 \\
\hline Anthracene & ${ }^{1} 120-12-7$ & ND & 390 & 3,040 & ND & 193 & 1,510 \\
\hline Benzo(a)anthracene & $156-55-3$ & ND & 429 & 3,040 & ND & 213 & 1,510 \\
\hline Benzo(a)pyrene & ${ }^{1} 50-32-8$ & ND & 434 & 3,040 & ND & 215 & 1,510 \\
\hline Benzo(b)fluoranthene & ${ }^{1} 205-99-2$ & ND & 434 & 3,040 & ND & 215 & 1,510 \\
\hline Benzo(g,h,i)perylene & ${ }^{1} 191-24-2$ & ND & 462 & 3,040 & ND & 229 & 1,510 \\
\hline Benzo(k)fluoranthene & ${ }^{1} 207-08-9$ & ND & 423 & 3,040 & ND & 209 & 1,510 \\
\hline Butylbenzylphthalate & $85-68-7$ & ND & 413 & 3,040 & ND & 205 & 1,510 \\
\hline Carbazole & $86-74-8$ & ND & 397 & 3,040 & ND & 197 & 1,510 \\
\hline Chrysene & ${ }^{1} 218-01-9$ & ND & 434 & 3,040 & ND & 215 & 1,510 \\
\hline Di-n-butylphthalate & $84-74-2$ & ND & 313 & 3,040 & ND & 155 & 1,510 \\
\hline Di-n-octylphthalate & $117-84-0$ & ND & 444 & 3,040 & ND & 220 & 1,510 \\
\hline Dibenz(a,h)anthracene & $153-70-3$ & ND & 472 & 3,040 & ND & 234 & 1,510 \\
\hline Dibenzofuran & $132-64-9$ & ND & 370 & 3,040 & ND & 183 & 1,510 \\
\hline
\end{tabular}


Table 11. Organic compound concentrations in bed-sediment core samples collected from selected sites at Brownlee Reservoir near Oxbow, Oregon, May 7-9, 2012.-Continued

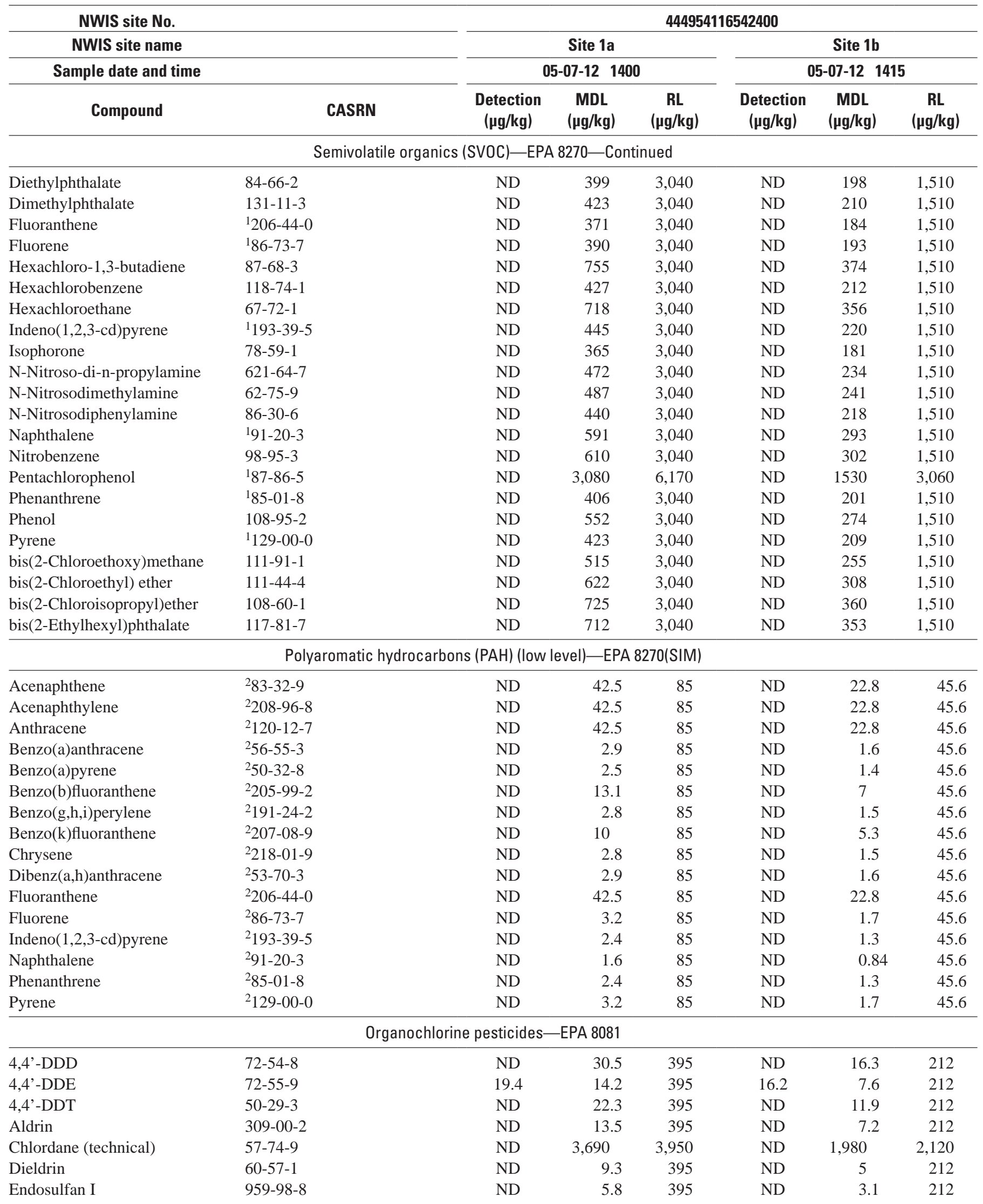


Table 11. Organic compound concentrations in bed-sediment core samples collected from selected sites at Brownlee Reservoir near Oxbow, Oregon, May 7-9, 2012.-Continued

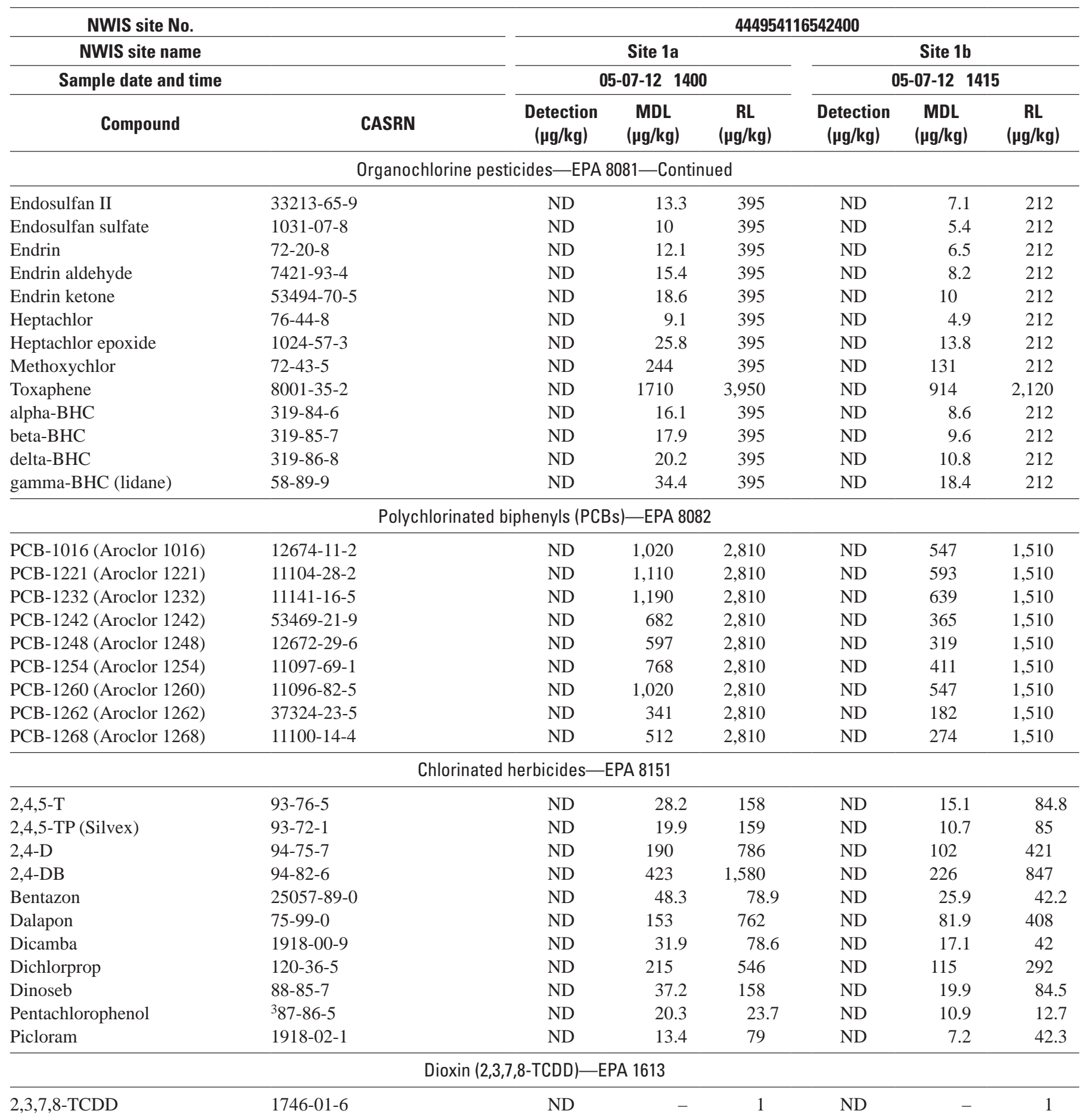


Table 11. Organic compound concentrations in bed-sediment core samples collected from selected sites at Brownlee Reservoir near Oxbow, Oregon, May 7-9, 2012.-Continued

\begin{tabular}{|c|c|c|c|c|c|c|c|}
\hline \multirow{2}{*}{$\begin{array}{c}\text { NWIS site No. } \\
\text { NWIS site name }\end{array}$} & & \multicolumn{6}{|c|}{444455117021200} \\
\hline & & \multicolumn{3}{|c|}{ Site 5a } & \multicolumn{3}{|c|}{ Site 5b } \\
\hline \multicolumn{2}{|l|}{ Sample date and time } & \multicolumn{3}{|c|}{$05-09-120900$} & \multicolumn{3}{|c|}{ 05-09-12 0915} \\
\hline Compound & CASRN & $\begin{array}{l}\text { Detection } \\
(\mu \mathrm{g} / \mathrm{kg})\end{array}$ & $\begin{array}{c}\text { MDL } \\
(\mu \mathrm{g} / \mathrm{kg})\end{array}$ & $\begin{array}{c}\text { RL } \\
(\mu \mathrm{g} / \mathrm{kg})\end{array}$ & $\begin{array}{l}\text { Detection } \\
(\mu \mathrm{g} / \mathrm{kg})\end{array}$ & $\begin{array}{c}\text { MDL } \\
(\mu \mathrm{g} / \mathrm{kg})\end{array}$ & $\begin{array}{c}\text { RL } \\
(\mu \mathrm{g} / \mathrm{kg})\end{array}$ \\
\hline \multicolumn{8}{|c|}{ Semivolatile organics (SVOC)_EPA 8270} \\
\hline 1,2,4-Trichlorobenzene & $120-82-1$ & ND & 441 & 2,130 & ND & 317 & 1,530 \\
\hline 1,2-Dichlorobenzene & $95-50-1$ & ND & 456 & 2,130 & ND & 328 & 1,530 \\
\hline 1,2-Diphenylhydrazine & $122-66-7$ & ND & 251 & 11,000 & ND & 180 & 7,880 \\
\hline 1,3-Dichlorobenzene & $541-73-1$ & ND & 487 & 2,130 & ND & 350 & 1,530 \\
\hline 1,4-Dichlorobenzene & $106-46-7$ & ND & 453 & 2,130 & ND & 326 & 1,530 \\
\hline 1-Methylnaphthalene & $90-12-0$ & ND & 307 & 2,130 & ND & 221 & 1,530 \\
\hline 2,4,5-Trichlorophenol & $95-95-4$ & ND & 365 & 11,000 & ND & 262 & 7,880 \\
\hline 2,4,6-Trichlorophenol & $88-06-2$ & ND & 315 & 2,130 & ND & 227 & 1,530 \\
\hline 2,4-Dichlorophenol & $120-83-2$ & ND & 318 & 2,130 & ND & 229 & 1,530 \\
\hline 2,4-Dimethylphenol & $105-67-9$ & ND & 1,060 & 2,130 & ND & 765 & 1,530 \\
\hline 2.4-Dinitrophenol & $51-28-5$ & ND & 305 & 11,000 & ND & 219 & 7,880 \\
\hline 2,4-Dinitrotoluene & $121-14-2$ & ND & 297 & 2,130 & ND & 214 & 1,530 \\
\hline 2.6-Dinitrotoluene & $606-20-2$ & ND & 297 & 2,130 & ND & 214 & 1,530 \\
\hline 2-Chloronaphthalene & $91-58-7$ & ND & 257 & 2,130 & ND & 184 & 1,530 \\
\hline 2-Chlorophenol & $95-57-8$ & ND & 467 & 2,130 & ND & 336 & 1,530 \\
\hline 2-Methylnaphthalene & $91-57-6$ & ND & 315 & 2,130 & ND & 226 & 1,530 \\
\hline 2-Methylphenol(o-Cresol) & $95-48-7$ & ND & 325 & 2,130 & ND & 234 & 1,530 \\
\hline 2-Nitroaniline & $88-74-4$ & ND & 295 & 11,000 & ND & 212 & 7,880 \\
\hline 2-Nitrophenol & $88-75-5$ & ND & 353 & 2,130 & ND & 254 & 1,530 \\
\hline 3\&4-Methylphenol & $108-39-4$ [3] and 106-44-5 [4] & ND & 286 & 4,250 & ND & 205 & 3,060 \\
\hline 3,3'-Dichlorobenzidine & $91-94-1$ & ND & 2,160 & 4,320 & ND & 1,550 & 3,110 \\
\hline 3-Nitroaniline & $99-09-2$ & ND & 418 & 11,000 & ND & 301 & 7,880 \\
\hline 4,6-Dinitro-2-methylphenol & $534-52-1$ & ND & 1,790 & 11,000 & ND & 1,290 & 7,880 \\
\hline 4-Bromophenylphenyl ether & $101-55-3$ & ND & 324 & 2,130 & ND & 233 & 1,530 \\
\hline 4-Chloro-3-methylphenol & $59-50-7$ & ND & 249 & 2,130 & ND & 179 & 1,530 \\
\hline 4-Chloroaniline & $106-47-8$ & ND & 1,060 & 2,130 & ND & 765 & 1,530 \\
\hline 4-Chlorophenylphenyl ether & $7005-72-3$ & ND & 286 & 2,130 & ND & 206 & 1,530 \\
\hline 4-Nitroaniline & $100-01-6$ & ND & 1,550 & 11,000 & ND & 1,120 & 7,880 \\
\hline 4-Nitrophenol & $100-02-7$ & ND & 5,480 & 11,000 & ND & 3,940 & 7,880 \\
\hline Acenaphthene & $183-32-9$ & ND & 252 & 2,130 & ND & 181 & 1,530 \\
\hline Acenaphthylene & ${ }^{1} 208-96-8$ & ND & 246 & 2,130 & ND & 177 & 1,530 \\
\hline Anthracene & ${ }^{1} 120-12-7$ & ND & 273 & 2,130 & ND & 197 & 1,530 \\
\hline Benzo(a)anthracene & $156-55-3$ & ND & 300 & 2,130 & ND & 216 & 1,530 \\
\hline Benzo(a)pyrene & $150-32-8$ & ND & 304 & 2,130 & ND & 219 & 1,530 \\
\hline Benzo(b)fluoranthene & ${ }^{1} 205-99-2$ & ND & 304 & 2,130 & ND & 219 & 1,530 \\
\hline Benzo(g,h,i)perylene & ${ }^{1} 191-24-2$ & ND & 324 & 2,130 & ND & 233 & 1,530 \\
\hline Benzo(k)fluoranthene & ${ }^{1} 207-08-9$ & ND & 296 & 2,130 & ND & 213 & 1,530 \\
\hline Butylbenzylphthalate & $85-68-7$ & ND & 289 & 2,130 & ND & 208 & 1,530 \\
\hline Carbazole & $86-74-8$ & ND & 278 & 2,130 & ND & 200 & 1,530 \\
\hline Chrysene & 1218-01-9 & ND & 304 & 2,130 & ND & 219 & 1,530 \\
\hline Di-n-butylphthalate & $84-74-2$ & ND & 219 & 2,130 & ND & 158 & 1,530 \\
\hline Di-n-octylphthalate & $117-84-0$ & ND & 311 & 2,130 & ND & 223 & 1,530 \\
\hline Dibenz(a,h)anthracene & $153-70-3$ & ND & 331 & 2,130 & ND & 238 & 1,530 \\
\hline Dibenzofuran & $132-64-9$ & ND & 259 & 2,130 & ND & 186 & 1,530 \\
\hline
\end{tabular}


Table 11. Organic compound concentrations in bed-sediment core samples collected from selected sites at Brownlee Reservoir near Oxbow, Oregon, May 7-9, 2012.-Continued

\begin{tabular}{|c|c|c|c|c|c|c|c|}
\hline \multirow{2}{*}{$\begin{array}{c}\text { NWIS site No. } \\
\text { NWIS site name }\end{array}$} & & \multicolumn{6}{|c|}{444455117021200} \\
\hline & & \multicolumn{3}{|c|}{ Site 5a } & \multicolumn{3}{|c|}{ Site 5b } \\
\hline \multicolumn{2}{|l|}{ Sample date and time } & \multicolumn{3}{|c|}{ 05-09-12 0900} & \multicolumn{3}{|c|}{ 05-09-12 0915} \\
\hline Compound & CASRN & $\begin{array}{l}\text { Detection } \\
(\mu \mathrm{g} / \mathrm{kg})\end{array}$ & $\begin{array}{c}\text { MDL } \\
(\mu \mathrm{g} / \mathrm{kg})\end{array}$ & $\underset{(\mu \mathrm{g} / \mathrm{kg})}{\mathbf{R L}}$ & $\begin{array}{l}\text { Detection } \\
(\mu \mathrm{g} / \mathrm{kg})\end{array}$ & $\begin{array}{c}\text { MDL } \\
(\mu \mathrm{g} / \mathbf{k g})\end{array}$ & $\begin{array}{c}\mathbf{R L} \\
(\mu \mathrm{g} / \mathrm{kg})\end{array}$ \\
\hline \multicolumn{8}{|c|}{ Semivolatile organics (SVOC)_EPA 8270_Continued } \\
\hline Diethylphthalate & 84-66-2 & ND & 279 & 2,130 & ND & 201 & 1,530 \\
\hline Dimethylphthalate & $131-11-3$ & ND & 296 & 2,130 & ND & 213 & 1,530 \\
\hline Fluoranthene & ${ }^{1} 206-44-0$ & ND & 260 & 2,130 & ND & 187 & 1,530 \\
\hline Fluorene & ${ }^{1} 86-73-7$ & ND & 273 & 2,130 & ND & 197 & 1,530 \\
\hline Hexachloro-1,3-butadiene & $87-68-3$ & ND & 528 & 2,130 & ND & 380 & 1,530 \\
\hline Hexachlorobenzene & $118-74-1$ & ND & 299 & 2,130 & ND & 215 & 1,530 \\
\hline Hexachloroethane & $67-72-1$ & ND & 503 & 2,130 & ND & 362 & 1,530 \\
\hline Indeno(1,2,3-cd)pyrene & ${ }^{1} 193-39-5$ & ND & 311 & 2,130 & ND & 224 & 1,530 \\
\hline Isophorone & $78-59-1$ & ND & 256 & 2,130 & ND & 184 & 1,530 \\
\hline N-Nitroso-di-n-propylamine & $621-64-7$ & ND & 331 & 2,130 & ND & 238 & 1,530 \\
\hline N-Nitrosodimethylamine & $62-75-9$ & ND & 341 & 2,130 & ND & 245 & 1,530 \\
\hline N-Nitrosodiphenylamine & $86-30-6$ & ND & 308 & 2,130 & ND & 222 & 1,530 \\
\hline Naphthalene & ${ }^{1} 91-20-3$ & ND & 414 & 2,130 & ND & 298 & 1,530 \\
\hline Nitrobenzene & $98-95-3$ & ND & 427 & 2,130 & ND & 307 & 1,530 \\
\hline Pentachlorophenol & $187-86-5$ & ND & 2,160 & 4,320 & ND & 1,550 & 3,110 \\
\hline Phenanthrene & ${ }^{1} 85-01-8$ & ND & 284 & 2,130 & ND & 204 & 1,530 \\
\hline Phenol & $108-95-2$ & ND & 387 & 2,130 & ND & 278 & 1,530 \\
\hline Pyrene & ${ }^{1} 129-00-0$ & ND & 296 & 2,130 & ND & 213 & 1,530 \\
\hline bis(2-Chloroethoxy)methane & $111-91-1$ & ND & 361 & 2,130 & ND & 260 & 1,530 \\
\hline bis(2-Chloroethyl) ether & $111-44-4$ & ND & 436 & 2,130 & ND & 313 & 1,530 \\
\hline bis(2-Chloroisopropyl)ether & $108-60-1$ & ND & 508 & 2,130 & ND & 365 & 1,530 \\
\hline bis(2-Ethylhexyl)phthalate & $117-81-7$ & ND & 499 & 2,130 & ND & 359 & 1,530 \\
\hline \multicolumn{8}{|c|}{ Polyaromatic hydrocarbons PAH (low level)_EPA 8270(SIM) } \\
\hline Acenaphthene & $283-32-9$ & ND & 32.9 & 65.8 & ND & 23.2 & 46.4 \\
\hline Acenaphthylene & ${ }^{2} 208-96-8$ & ND & 32.9 & 65.8 & ND & 23.2 & 46.4 \\
\hline Anthracene & ${ }^{2} 120-12-7$ & ND & 32.9 & 65.8 & ND & 23.2 & 46.4 \\
\hline Benzo(a)anthracene & $256-55-3$ & ND & 2.2 & 65.8 & ND & 1.6 & 46.4 \\
\hline Benzo(a)pyrene & ${ }^{2} 50-32-8$ & ND & 2 & 65.8 & ND & 1.4 & 46.4 \\
\hline Benzo(b)fluoranthene & ${ }^{2} 205-99-2$ & ND & 10.1 & 65.8 & ND & 7.1 & 46.4 \\
\hline Benzo(g,h,i)perylene & ${ }^{2} 191-24-2$ & ND & 2.2 & 65.8 & ND & 1.5 & 46.4 \\
\hline Benzo(k)fluoranthene & ${ }^{2} 207-08-9$ & ND & 7.7 & 65.8 & ND & 5.4 & 46.4 \\
\hline Chrysene & ${ }^{2} 218-01-9$ & ND & 2.1 & 65.8 & ND & 1.5 & 46.4 \\
\hline Dibenz(a,h)anthracene & $253-70-3$ & ND & 2.2 & 65.8 & ND & 1.6 & 46.4 \\
\hline Fluoranthene & ${ }^{2} 206-44-0$ & ND & 32.9 & 65.8 & ND & 23.2 & 46.4 \\
\hline Fluorene & $286-73-7$ & ND & 2.5 & 65.8 & ND & 1.7 & 46.4 \\
\hline Indeno(1,2,3-cd)pyrene & ${ }^{2} 193-39-5$ & ND & 1.9 & 65.8 & ND & 1.3 & 46.4 \\
\hline Naphthalene & $291-20-3$ & ND & 1.2 & 65.8 & ND & 0.86 & 46.4 \\
\hline Phenanthrene & ${ }^{2} 85-01-8$ & ND & 1.9 & 65.8 & ND & 1.3 & 46.4 \\
\hline Pyrene & ${ }^{2} 129-00-0$ & ND & 2.5 & 65.8 & ND & 1.7 & 46.4 \\
\hline \multicolumn{8}{|c|}{ Organochlorine pesticides_EPA 8081} \\
\hline 4,4'-DDD & $72-54-8$ & ND & 23.5 & 305 & ND & 16.6 & 215 \\
\hline 4,4'-DDE & $72-55-9$ & 14.3 & 10.9 & 305 & 14.3 & 7.7 & 215 \\
\hline 4,4'-DDT & $50-29-3$ & ND & 17.2 & 305 & ND & 12.1 & 215 \\
\hline Aldrin & $309-00-2$ & ND & 10.4 & 305 & ND & 7.3 & 215 \\
\hline Chlordane (technical) & $57-74-9$ & ND & 2,850 & 3,050 & ND & 2,010 & 2,150 \\
\hline Dieldrin & $60-57-1$ & ND & 7.2 & 305 & ND & 5.1 & 215 \\
\hline Endosulfan I & 959-98-8 & ND & 4.5 & 305 & ND & 3.2 & 215 \\
\hline
\end{tabular}


Table 11. Organic compound concentrations in bed-sediment core samples collected from selected sites at Brownlee Reservoir near Oxbow, Oregon, May 7-9, 2012.-Continued

\begin{tabular}{|c|c|c|c|c|c|c|c|}
\hline \multirow{2}{*}{$\begin{array}{c}\text { NWIS site No. } \\
\text { NWIS site name }\end{array}$} & & \multicolumn{6}{|c|}{444455117021200} \\
\hline & & \multicolumn{3}{|c|}{ Site 5a } & \multicolumn{3}{|c|}{ Site $5 b$} \\
\hline \multicolumn{2}{|l|}{ Sample date and time } & \multicolumn{3}{|c|}{ 05-09-12 0900} & \multicolumn{3}{|c|}{ 05-09-12 0915} \\
\hline Compound & CASRN & $\begin{array}{l}\text { Detection } \\
(\mu \mathrm{g} / \mathrm{kg})\end{array}$ & $\begin{array}{c}\text { MDL } \\
(\mu \mathrm{g} / \mathrm{kg})\end{array}$ & $\underset{(\mu \mathrm{g} / \mathrm{kg})}{\mathbf{R L}}$ & $\begin{array}{l}\text { Detection } \\
(\mu \mathrm{g} / \mathrm{kg})\end{array}$ & $\begin{array}{c}\text { MDL } \\
(\mu \mathrm{g} / \mathrm{kg})\end{array}$ & $\begin{array}{c}R L \\
(\mu \mathrm{g} / \mathrm{kg})\end{array}$ \\
\hline \multicolumn{8}{|c|}{ Organochlorine pesticides-EPA 8081-Continued } \\
\hline Endosulfan II & $33213-65-9$ & ND & 10.2 & 305 & ND & 7.2 & 215 \\
\hline Endosulfan sulfate & 1031-07-8 & ND & 7.7 & 305 & ND & 5.4 & 215 \\
\hline Endrin & $72-20-8$ & ND & 9.3 & 305 & ND & 6.6 & 215 \\
\hline Endrin aldehyde & 7421-93-4 & ND & 11.8 & 305 & ND & 8.3 & 215 \\
\hline Endrin ketone & 53494-70-5 & ND & 14.3 & 305 & ND & 10.1 & 215 \\
\hline Heptachlor & $76-44-8$ & ND & 7 & 305 & ND & 4.9 & 215 \\
\hline Heptachlor epoxide & $1024-57-3$ & ND & 19.9 & 305 & ND & 14 & 215 \\
\hline Methoxychlor & $72-43-5$ & ND & 188 & 305 & ND & 133 & 215 \\
\hline Toxaphene & $8001-35-2$ & ND & 1,320 & 3,050 & ND & 929 & 2,150 \\
\hline alpha-BHC & $319-84-6$ & ND & 12.4 & 305 & ND & 8.7 & 215 \\
\hline beta-BHC & $319-85-7$ & ND & 13.8 & 305 & ND & 9.7 & 215 \\
\hline delta-BHC & 319-86-8 & ND & 15.6 & 305 & ND & 11 & 215 \\
\hline gamma-BHC (lidane) & $58-89-9$ & ND & 26.5 & 305 & ND & 18.7 & 215 \\
\hline \multicolumn{8}{|c|}{ Polychlorinated biphenyls (PCBs)_EPA 8082} \\
\hline PCB-1016 (Aroclor 1016) & $12674-11-2$ & - & - & - & ND & 556 & 1,530 \\
\hline PCB-1221 (Aroclor 1221) & $11104-28-2$ & - & - & - & ND & 603 & 1,530 \\
\hline PCB-1232 (Aroclor 1232) & $11141-16-5$ & - & - & - & ND & 649 & 1,530 \\
\hline PCB-1242 (Aroclor 1242) & $53469-21-9$ & - & - & - & ND & 371 & 1,530 \\
\hline PCB-1248 (Aroclor 1248) & $12672-29-6$ & - & - & - & ND & 324 & 1,530 \\
\hline PCB-1254 (Aroclor 1254) & 11097-69-1 & - & - & - & ND & 417 & 1,530 \\
\hline PCB-1260 (Aroclor 1260) & $11096-82-5$ & - & - & - & ND & 556 & 1,530 \\
\hline PCB-1262 (Aroclor 1262) & $37324-23-5$ & - & - & - & ND & 185 & 1,530 \\
\hline PCB-1268 (Aroclor 1268) & $11100-14-4$ & - & - & - & ND & 278 & 1,530 \\
\hline \multicolumn{8}{|c|}{ Chlorinated herbicides_-EPA 8151} \\
\hline $2,4,5-\mathrm{T}$ & $93-76-5$ & - & - & - & - & - & - \\
\hline 2,4,5-TP (Silvex) & $93-72-1$ & - & - & - & - & - & - \\
\hline $2,4-\mathrm{D}$ & $94-75-7$ & - & - & - & - & - & - \\
\hline 2,4-DB & $94-82-6$ & - & - & - & - & - & - \\
\hline Bentazon & 25057-89-0 & - & - & - & - & - & - \\
\hline Dalapon & $75-99-0$ & - & - & - & - & - & - \\
\hline Dicamba & 1918-00-9 & - & - & - & - & - & - \\
\hline Dichlorprop & $120-36-5$ & - & - & - & - & - & - \\
\hline Dinoseb & $88-85-7$ & - & - & - & - & - & - \\
\hline Pentachlorophenol & $387-86-5$ & - & - & - & - & - & - \\
\hline Picloram & 1918-02-1 & - & - & - & - & - & - \\
\hline \multicolumn{8}{|c|}{ Dioxin (2,3,7,8-TCDD)—EPA 1613} \\
\hline 2,3,7,8-TCDD & $1746-01-6$ & ND & - & 1 & ND & - & 1 \\
\hline
\end{tabular}


Table 11. Organic compound concentrations in bed-sediment core samples collected from selected sites at Brownlee Reservoir near Oxbow, Oregon, May 7-9, 2012.-Continued

\begin{tabular}{|c|c|c|c|c|c|c|c|}
\hline \multirow{3}{*}{$\begin{array}{c}\text { NWIS site No. } \\
\text { NWIS site name } \\
\text { Sample date and time }\end{array}$} & & \multicolumn{6}{|c|}{443416117084000} \\
\hline & & \multicolumn{3}{|c|}{ Site 8a } & \multicolumn{3}{|c|}{ Site 8b } \\
\hline & & \multicolumn{3}{|c|}{ 05-08-12 0900} & \multicolumn{3}{|c|}{ 05-08-12 0915} \\
\hline Compound & CASRN & $\begin{array}{c}\text { Detection } \\
(\mu \mathrm{g} / \mathrm{kg})\end{array}$ & $\begin{array}{c}\text { MDL } \\
(\mu \mathrm{g} / \mathrm{kg})\end{array}$ & $\underset{(\mu \mathrm{g} / \mathrm{kg})}{\mathbf{R L}}$ & $\begin{array}{c}\text { Detection } \\
(\mu \mathrm{g} / \mathrm{kg})\end{array}$ & $\begin{array}{c}\text { MDL } \\
(\mu \mathrm{g} / \mathrm{kg})\end{array}$ & $\begin{array}{c}\text { RL } \\
(\mu \mathrm{g} / \mathrm{kg})\end{array}$ \\
\hline \multicolumn{8}{|c|}{ Semivolatile organics (SVOC)_EPA 8270} \\
\hline 1,2,4-Trichlorobenzene & $120-82-1$ & ND & 295 & 1,420 & ND & 258 & 1,250 \\
\hline 1,2-Dichlorobenzene & $95-50-1$ & ND & 305 & 1,420 & ND & 267 & 1,250 \\
\hline 1,2-Diphenylhydrazine & $122-66-7$ & ND & 168 & 7,320 & ND & 147 & 6,420 \\
\hline 1,3-Dichlorobenzene & $541-73-1$ & ND & 325 & 1,420 & ND & 285 & 1,250 \\
\hline 1,4-Dichlorobenzene & $106-46-7$ & ND & 303 & 1,420 & ND & 265 & 1,250 \\
\hline 1-Methylnaphthalene & $90-12-0$ & ND & 205 & 1,420 & ND & 180 & 1,250 \\
\hline 2,4,5-Trichlorophenol & $95-95-4$ & ND & 244 & 7,320 & ND & 214 & 6,420 \\
\hline 2,4,6-Trichlorophenol & $88-06-2$ & ND & 211 & 1,420 & ND & 185 & 1,250 \\
\hline 2,4-Dichlorophenol & $120-83-2$ & ND & 213 & 1,420 & ND & 186 & 1,250 \\
\hline 2,4-Dimethylphenol & $105-67-9$ & ND & 711 & 1,420 & ND & 623 & 1,250 \\
\hline 2.4-Dinitrophenol & $51-28-5$ & ND & 204 & 7,320 & ND & 179 & 6,420 \\
\hline 2,4-Dinitrotoluene & $121-14-2$ & ND & 199 & 1,420 & ND & 174 & 1,250 \\
\hline 2.6-Dinitrotoluene & $606-20-2$ & ND & 199 & 1,420 & ND & 174 & 1,250 \\
\hline 2-Chloronaphthalene & $91-58-7$ & ND & 171 & 1,420 & ND & 150 & 1,250 \\
\hline 2-Chlorophenol & $95-57-8$ & ND & 312 & 1,420 & ND & 274 & 1,250 \\
\hline 2-Methylnaphthalene & $91-57-6$ & ND & 210 & 1,420 & ND & 184 & 1,250 \\
\hline 2-Methylphenol(o-Cresol) & $95-48-7$ & ND & 218 & 1,420 & ND & 191 & 1,250 \\
\hline 2-Nitroaniline & $88-74-4$ & ND & 197 & 7,320 & ND & 173 & 6,420 \\
\hline 2-Nitrophenol & $88-75-5$ & ND & 236 & 1,420 & ND & 206 & 1,250 \\
\hline 3\&4-Methylphenol & 108-39-4 [3] and 106-44-5 [4] & ND & 191 & 2,840 & ND & 167 & 2,490 \\
\hline 3,3’-Dichlorobenzidine & $91-94-1$ & ND & 1,440 & 2,890 & ND & 1,260 & 2,530 \\
\hline 3-Nitroaniline & $99-09-2$ & ND & 280 & 7,320 & ND & 245 & 6,420 \\
\hline 4,6-Dinitro-2-methylphenol & $534-52-1$ & ND & 1,200 & 7,320 & ND & 1,050 & 6,420 \\
\hline 4-Bromophenylphenyl ether & $101-55-3$ & ND & 217 & 1,420 & ND & 190 & 1,250 \\
\hline 4-Chloro-3-methylphenol & $59-50-7$ & ND & 167 & 1,420 & ND & 146 & 1,250 \\
\hline 4-Chloroaniline & $106-47-8$ & ND & 711 & 1,420 & ND & 623 & 1,250 \\
\hline 4-Chlorophenylphenyl ether & $7005-72-3$ & ND & 191 & 1,420 & ND & 168 & 1,250 \\
\hline 4-Nitroaniline & $100-01-6$ & ND & 1,040 & 7,320 & ND & 910 & 6,420 \\
\hline 4-Nitrophenol & $100-02-7$ & ND & 3,660 & 7,320 & ND & 3,210 & 6,420 \\
\hline Acenaphthene & 183-32-9 & ND & 168 & 1,420 & ND & 148 & 1,250 \\
\hline Acenaphthylene & ${ }^{1} 208-96-8$ & ND & 165 & 1,420 & ND & 144 & 1,250 \\
\hline Anthracene & ${ }^{1} 120-12-7$ & ND & 183 & 1,420 & ND & 160 & 1,250 \\
\hline Benzo(a)anthracene & $156-55-3$ & ND & 201 & 1,420 & ND & 176 & 1,250 \\
\hline Benzo(a)pyrene & $150-32-8$ & ND & 203 & 1,420 & ND & 178 & 1,250 \\
\hline Benzo(b)fluoranthene & ${ }^{12} 205-99-2$ & ND & 203 & 1,420 & ND & 178 & 1,250 \\
\hline Benzo(g,h,i)perylene & ${ }^{1} 191-24-2$ & ND & 216 & 1,420 & ND & 189 & 1,250 \\
\hline Benzo(k)fluoranthene & ${ }^{1207-08-9}$ & ND & 198 & 1,420 & ND & 173 & 1,250 \\
\hline Butylbenzylphthalate & $85-68-7$ & ND & 193 & 1,420 & ND & 169 & 1,250 \\
\hline Carbazole & $86-74-8$ & ND & 186 & 1,420 & ND & 163 & 1,250 \\
\hline Chrysene & $1218-01-9$ & ND & 203 & 1,420 & ND & 178 & 1,250 \\
\hline Di-n-butylphthalate & $84-74-2$ & ND & 146 & 1,420 & ND & 128 & 1,250 \\
\hline Di-n-octylphthalate & $117-84-0$ & ND & 208 & 1,420 & ND & 182 & 1,250 \\
\hline Dibenz(a,h)anthracene & $153-70-3$ & ND & 221 & 1,420 & ND & 194 & 1,250 \\
\hline Dibenzofuran & $132-64-9$ & ND & 173 & 1,420 & ND & 152 & 1,250 \\
\hline
\end{tabular}


Table 11. Organic compound concentrations in bed-sediment core samples collected from selected sites at Brownlee Reservoir near Oxbow, Oregon, May 7-9, 2012.-Continued

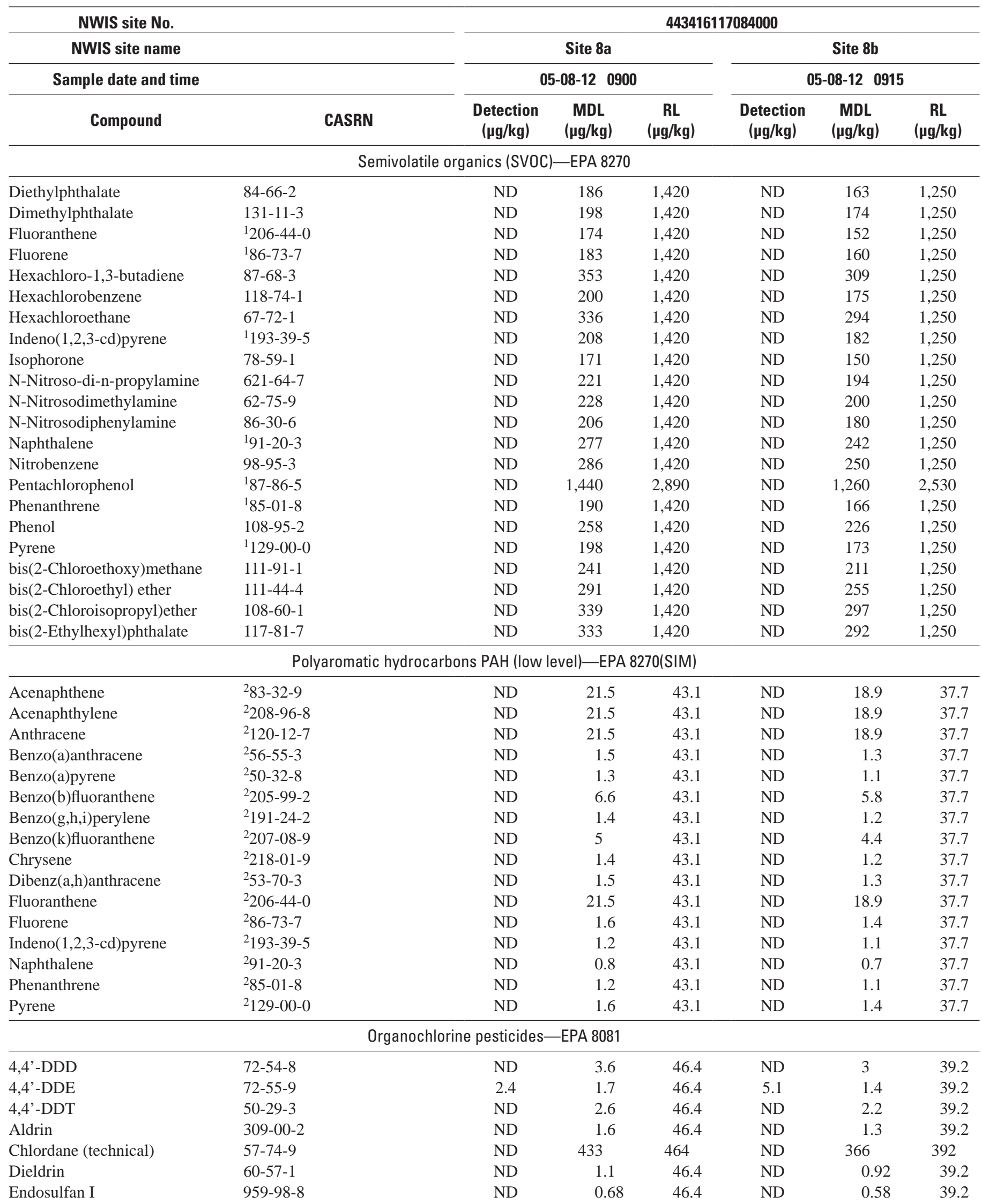


Table 11. Organic compound concentrations in bed-sediment core samples collected from selected sites at Brownlee Reservoir near Oxbow, Oregon, May 7-9, 2012.-Continued

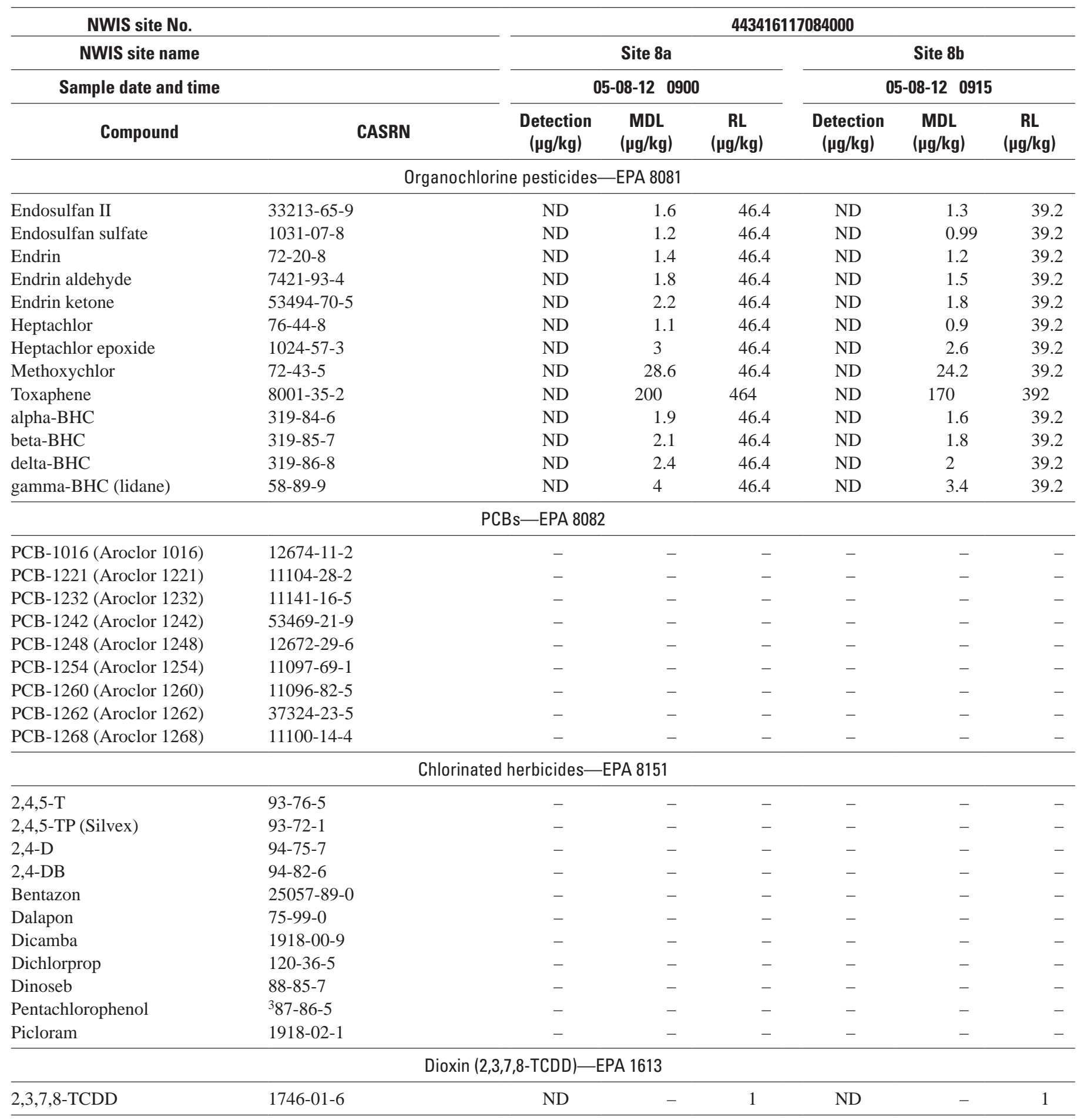

${ }^{1}$ Analytical Method: EPA 8270 Preparation Method: EPA 3550.

${ }^{2}$ Analytical Method: EPA 8270 by SIM Preparation Method: EPA 3550.

${ }^{3}$ Analytical Method: EPA 8151. 


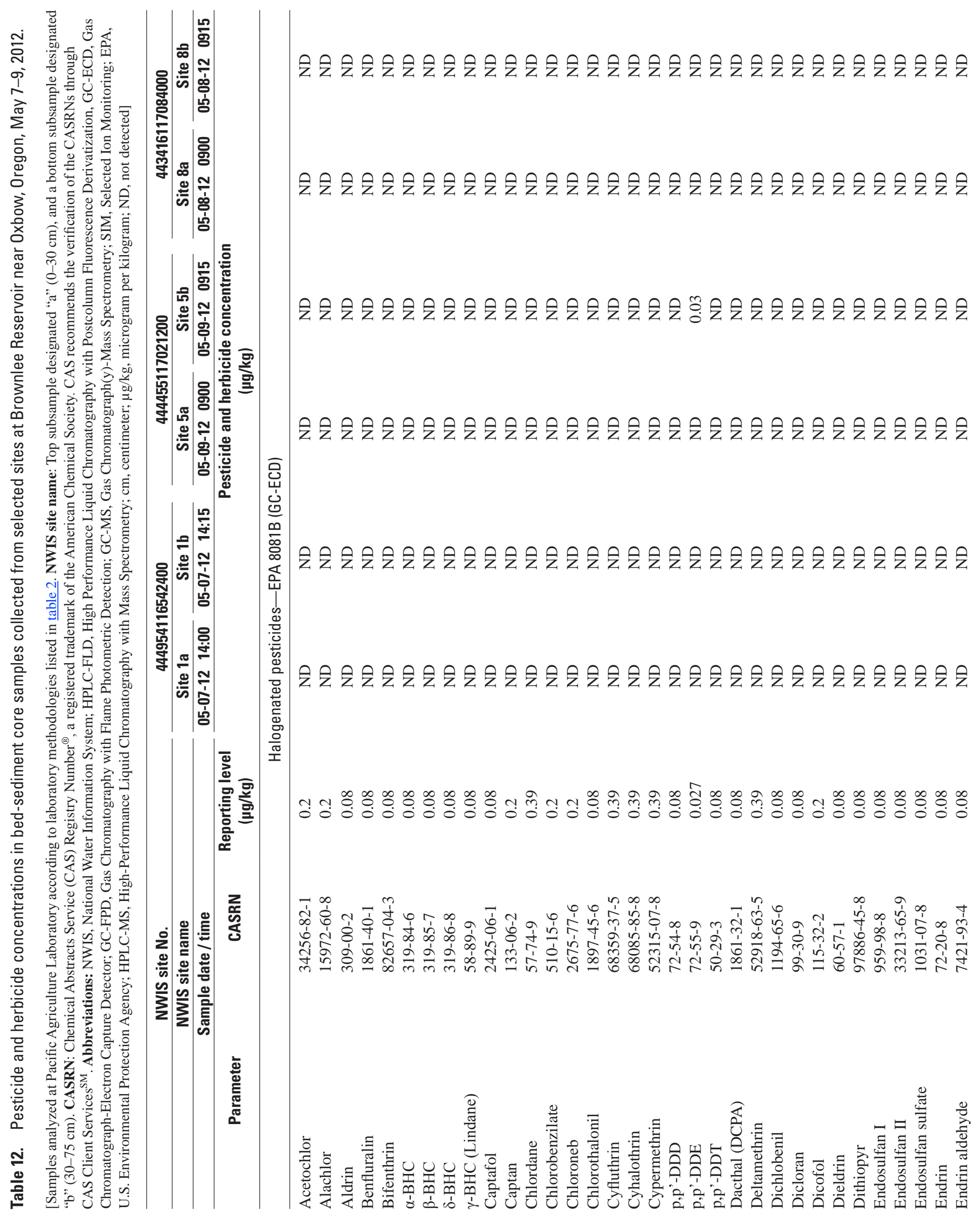




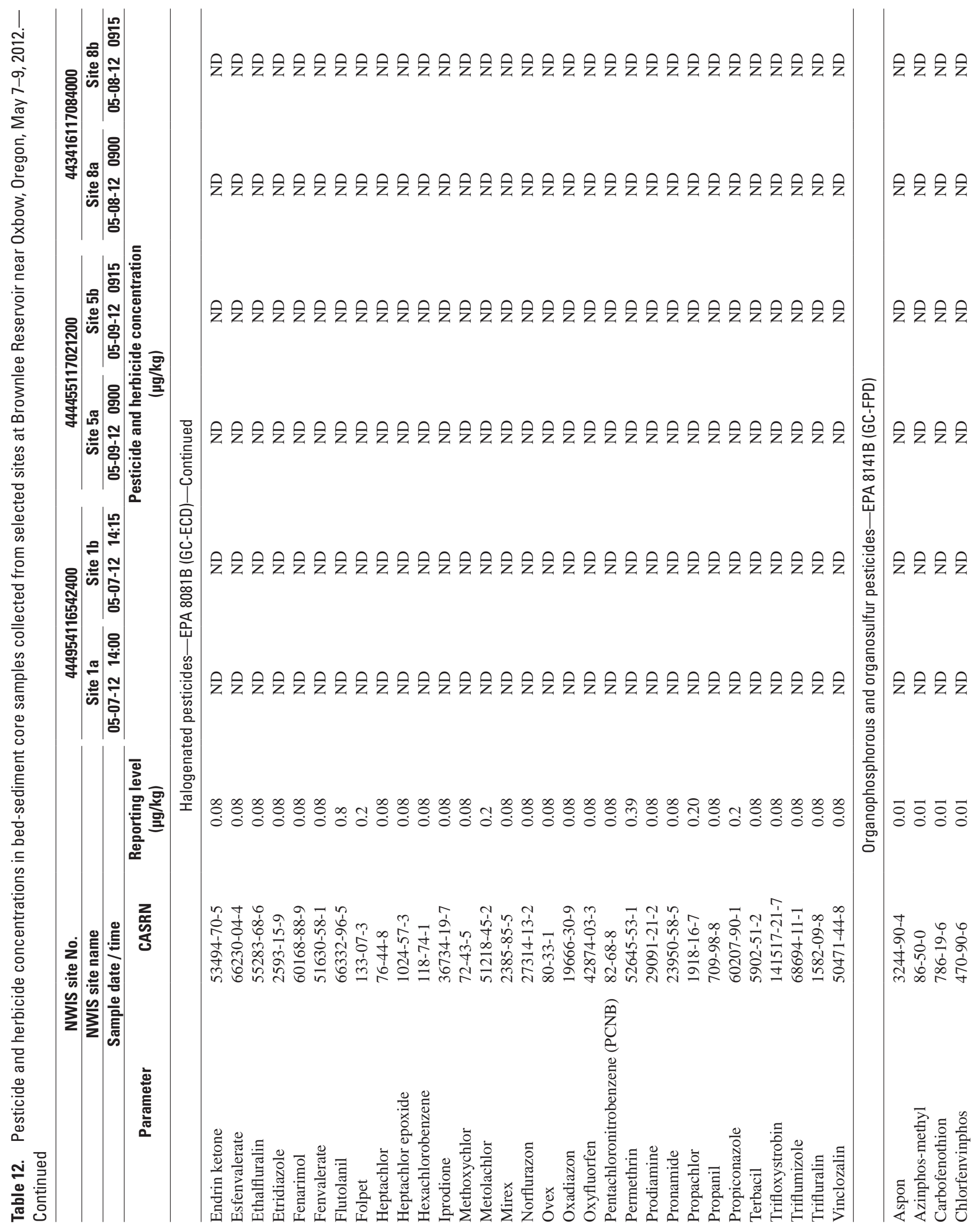




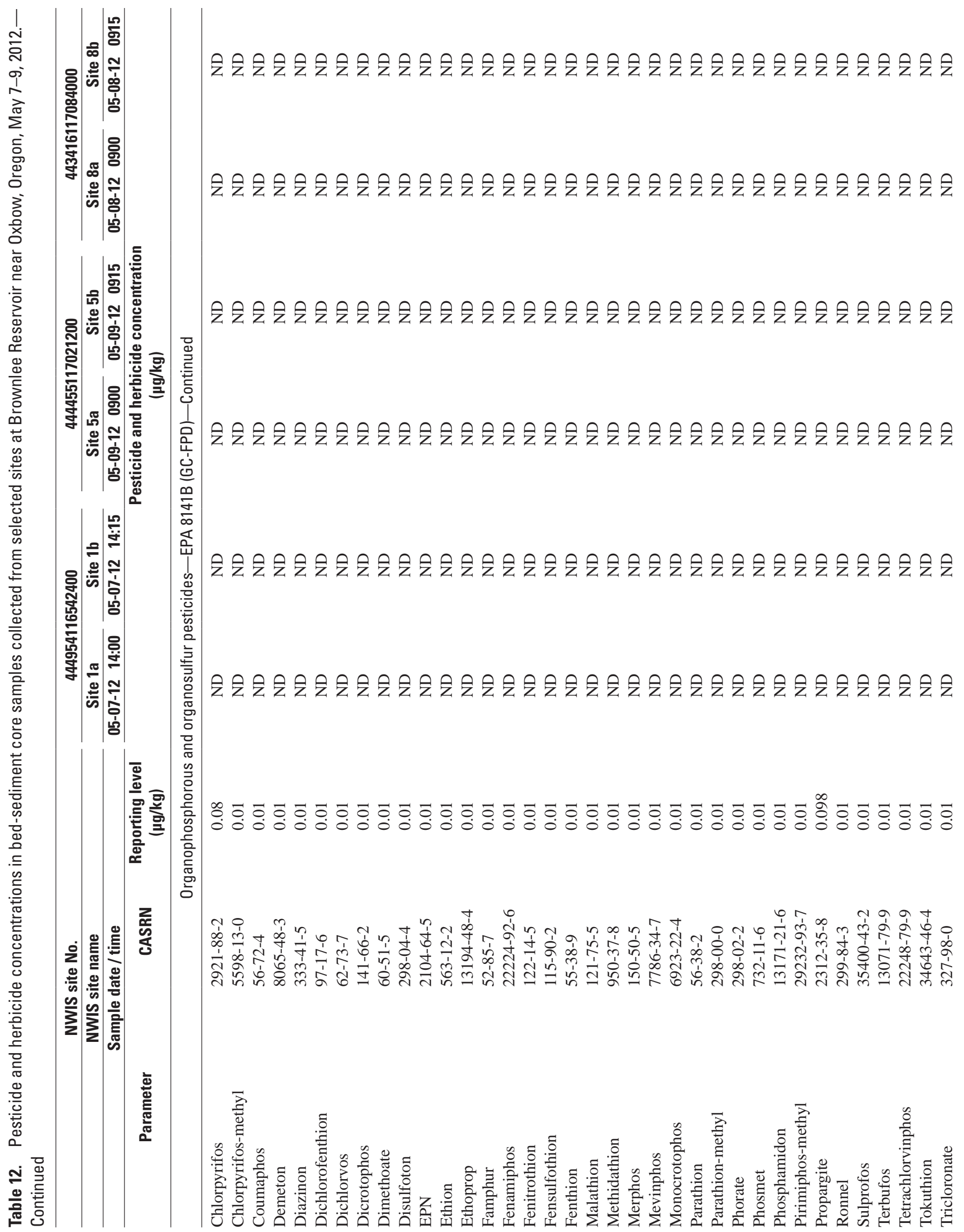




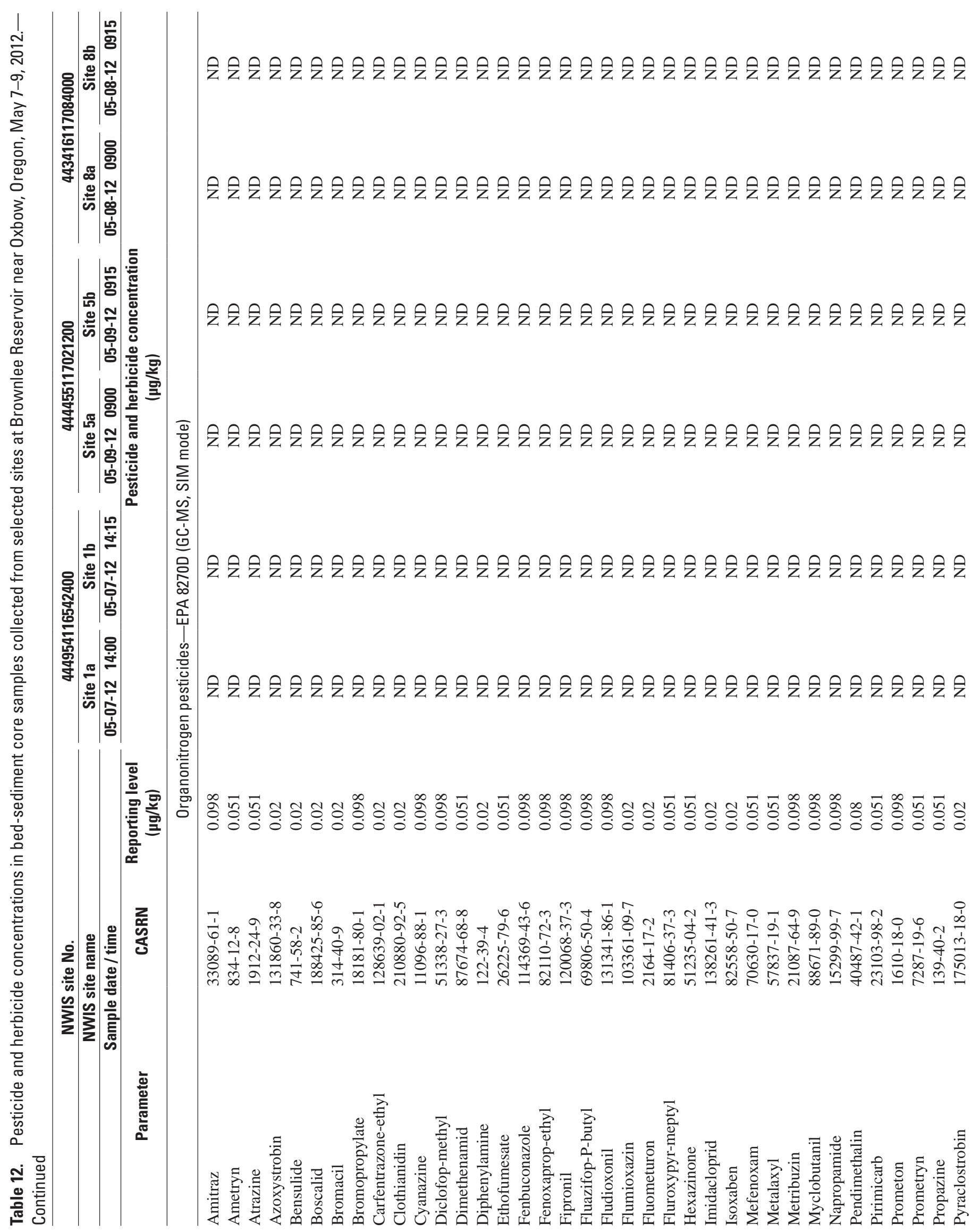




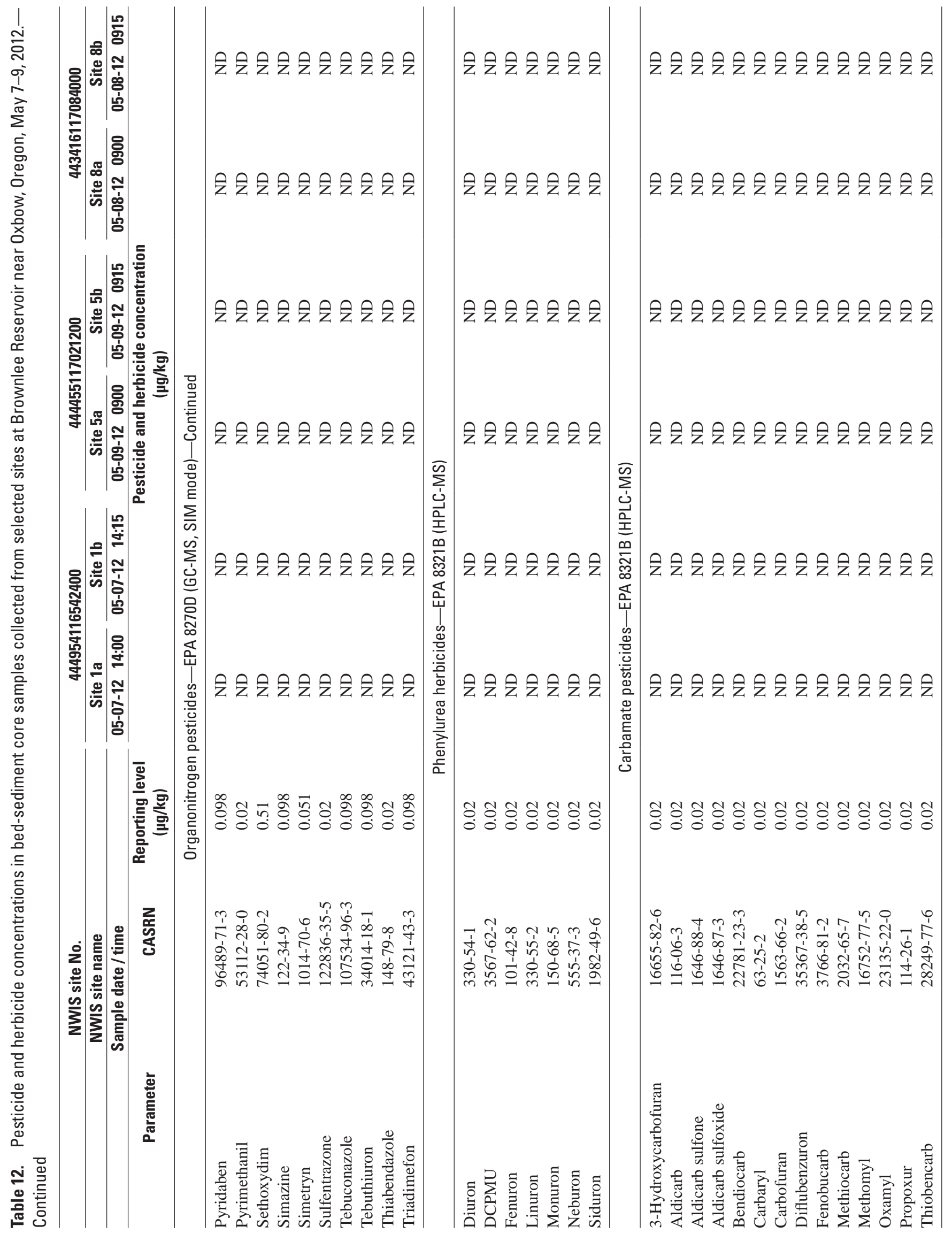



Publishing support provided by the U.S. Geological Survey Publishing Network, Tacoma Publishing Service Center

For more information concerning the research in this report, contact the Director, Idaho Water Science Center

U.S. Geological Survey

230 Collins Road

Boise, Idaho 83702

http://id.water.usgs.gov 
